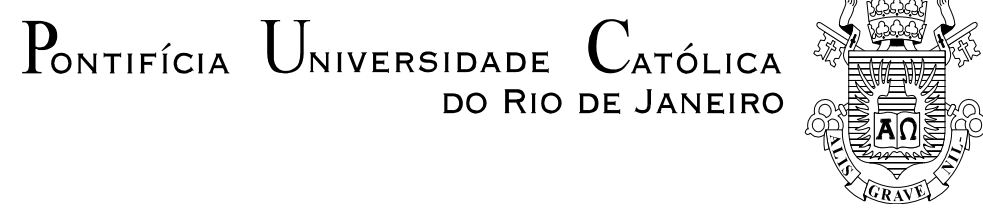

Raquel Costa Dias

\title{
A Repressão Criminal ao Poder Constituinte: \\ As jornadas de junho de 2013 no Rio de Janeiro \\ e o processo penal
}

Dissertação de Mestrado

Dissertação apresentada como requisito parcial para obtenção do grau de Mestre pelo Programa de Pósgraduação em Direito do Departamento de Direito da PUC-Rio.

Orientador: Prof. Adriano Pilatti Coorientadora: Profa . Victória-Amália de Barros Carvalho Gozdawa de Sulocki 


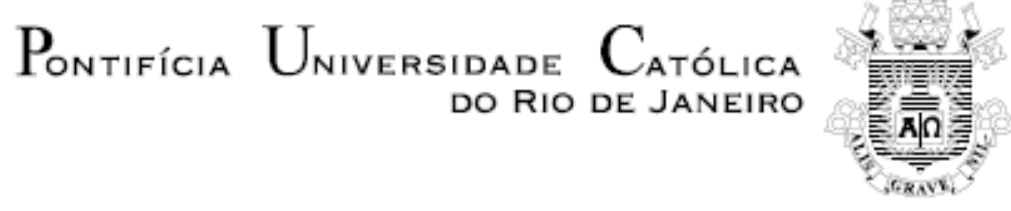

Raquel Costa Dias

\begin{abstract}
A Repressão Criminal ao Poder Constituinte: As jornadas de junho de 2013 no Rio de Janeiro e o processo penal
\end{abstract}

Dissertação apresentada como requisito parcial para obtenção do título de Mestre pelo Programa de Pósgraduação em Direito do Departamento de Direito da PUC-Rio. Aprovada pela Comissão Examinadora abaixo assinada.

Prof. Adriano Pilatti

Orientador

Departamento de Direito - PUC-Rio

Profa. Victória-Amália de Barros Carvalho Gozdawa de Sulocki

Co-orientadora

Departamento de Direito - PUC-Rio

Prof. Alexandre Fabiano Mendes

UERJ

Prof. Rubens Roberto Rebello Casara

Prof. Augusto César Pinheiro da Silva

Vice-Decano Setorial de Pós-Graduação do

Centro de Ciências Sociais - PUC-Rio

Rio de Janeiro, 19 de Julho de 2017. 
Todos os direitos reservados. É proibida a reprodução total ou parcial do trabalho sem autorização da universidade, do autor e do orientador.

\section{Raquel Costa Dias}

Graduada em Direito pela PUC-Rio (2008). Candidata ao título de mestre em Direito pela Pontifícia Universidade Católica do Rio de Janeiro. Tem como principal área de interesse o pensamento constitucional, direitos fundamentais e democracia.

Ficha Catalográfica

Dias, Raquel Costa

A repressão criminal ao poder constituinte: as jornadas de junho de 2013 no Rio de Janeiro e o processo penal / Raquel Costa Dias; orientador: Adriano Pilatti - 2017.

137 f. ; $30 \mathrm{~cm}$

Dissertação (mestrado) - Pontifícia Universidade Católica do Rio de Janeiro, Departamento de Direito, 2017. Inclui bibliografia

1. Direito - Teses. 2. Poder Constituinte. 3. Repressão. 4. Jornadas de 2013. 5. Resistência. 6. Processo Penal. I. Pilatti, Adriano. II. Pontifícia Universidade Católica do Rio de Janeiro. 
Aos meus avós, Diogo e Adelina, e minhas sobrinhas amadas, Juju e Lulu, por alegrarem minha alma e me despertarem um amor genuíno. 


\section{Agradecimentos}

Agradeço a minha mãe, pela parceria inconteste, por dividir comigo meus melhores e piores momentos, desde aquela noite de verão de $1984 \ldots$ Obrigada por ter me dado todo o apoio necessário para chegar até aqui, por nunca endossar os meus anseios de desistir quando os obstáculos eram grandes demais. Não fosse você esse exemplo de mulher forte, contestadora, inteligente e generosa, eu não teria alcançado mais essa vitória. Obrigada, mãe.

Ao meu pai, pelas conversas sempre apaixonadas sobre política e pelo amor ao Botafogo. Obrigada pelos estímulos às minhas aspirações profissionais e pessoais, sem os quais a minha inconformidade não acharia o meu desejo de luta, verdadeira válvula de escape encontrada nos estudos, no trabalho e na família Terço, a quem também agradeço.

Aos meus irmãos, Ana Carolina e Sérgio Luiz, porque, como costumo dizer "só quem tem irmão sabe o que é sentir esse amor incondicional". Obrigada por me ensinarem que o amor supera todas as diferenças e que vocês serão sempre os primeiros a chegar, na alegria e na tristeza.

Aos meus avós, a quem dedico esse trabalho em razão de suas vidas serem exemplos de força e luta, mas a eles devo agradecer profundamente por terem me recebido em sua casa e por fazerem o possível para que os meus estudos sempre estivessem em primeiro lugar. Agradeço também por deixarem sua casa aberta para mim a qualquer dia e a qualquer hora, pronta para me receber com amor, carinho e 'comida de vó'.

Às minhas cuidadoras de corpo e mente, Dra. Andrea e Viviane, e às minhas protetoras de alma e espírito, Graça e Janayna. Eu jamais conseguiria chegar aqui sem a força que vocês me ajudam a ter. Meu corpo e meu coração agradecem.

Aos meus sócios e colegas do escritório Paulo Freitas Ribeiro Advogados Associados, que há dez anos abriu suas portas para mim e, desde então, através dessa minha segunda família, me dá exemplos diários de lealdade profissional, dedicação integral às causas e respeito às diferenças. Obrigada Paulo, Rodrigo, Ivan e Camila, pelo apoio a essa fase da minha vida, por terem me integrado à sociedade em meio à fase final do Mestrado e, especialmente, por me ensinarem tudo o que eu sei a respeito da advocacia criminal. Obrigada Vitor e João, por integrarem a família PFR com muita dedicação, e também por sempre estarem dispostos a me ajudar.

Agradeço igualmente ao corpo administrativo do escritório e aos estagiários, sem os quais eu não teria conseguido chegar até aqui. Obrigada Sandra, desejo a você uma brevíssima recuperação e que logo possa retornar definitivamente ao 
escritório, cujo coração é você. Obrigada também à Jaque, pelos mimos ao longo desses dez anos. Obrigada Adriana, Roberto e Isabela, enfim, a todos vocês pela dedicação incansável às nossas muitas demandas, pelo carinho e respeito. Obrigada, Matheus e Bruno, a quem agradeço em nome de todos os estagiários, pelo apoio e lealdade.

À Ju, Bibs, Ludolf e Paty, pelo quinteto incrível que formamos desde os bancos da faculdade. À Marinex e ao Luizo, pela amizade sincera e respeitosa que cresce junto com o amor de vocês. À Julia, Titia, Ciça, Tamer e Alice, pela amizade e pelas peregrinações divertidas atrás de um bom samba sempre. À Micheli, Lelê e Marina pela torcida e pelas duas décadas de amizade. À Mineira, pela presença carinhosa que resiste a distância. À Rebeca pela amizade construída nesse Mestrado e pela força que, sem a qual, seria muito mais difícil terminar.

Ao meu orientador Adriano Pilatti, pela gigantesca generosidade, pelo estímulo de suas aulas cativantes, pela atenção e compreensão de momentos muito difíceis superados nestes últimos dois anos, e por sempre surpreender positivamente com sua habilidade cirúrgica ao desafiar o consenso. Muito obrigada, Professor, por tudo.

À minha coorientadora, Professora Victória-Amália de Sulocki, pela gentileza e disponibilidade ao aturar minhas incursões junto ao Departamento, me recebendo sempre com sua alegria intrínseca e altíssima capacidade para indicar quais os caminhos deveriam ser por mim seguidos. Obrigada por contribuir tanto para este trabalho, com sua paciência e sabedoria incríveis. Você é um exemplo, Professora.

À Fernanda Prates, mulher incrível que, além de ter sido a principal colaboradora do Grupo Habeas Corpus, através do qual construímos essa amizade, pacientemente recebeu meus e-mails incansáveis e, gentilmente, respondeu a todos eles. Ao Antônio Pedro Melchior que, desde 2015, esteve disponível para colaborar, acrescentar e enriquecer o debate a respeito do tema. Muito obrigada aos dois que, para mim, são grandes exemplos da excelente junção entre advocacia criminal e pesquisa acadêmica.

Ao G6, grupo de amigos formado nas aulas matinais de sábados na graduação da PUC, sem os quais a vida teria muito menos graça. Ao longo desses onze anos crescemos, somos agora um grupo formado também pelos respectivos e amados maridos e esposas e, recentemente, pelos lindos bebês da nova geração do G6. A todos vocês, muitíssimo obrigada pela contínua troca de experiências e pela demonstração diária de que somos um lindo exemplo de amizade.

À mais maravilhosa turma de Mestrado, a turma Amor y Juego, que enriquece a minha vida com seus exemplos de brilhantismo, parceria e senso de humor. Adoro vocês demais! Vocês tornaram a minha vida profissional, acadêmica e pessoal muito mais leve e divertida nestes últimos 2 anos! Que assim seja sempre. Obrigada!

Aos incansáveis, brilhantes e dedicados, Anderson e Carmen. Muitíssimo obrigada por terem resposta para tudo. Vocês são incríveis. 


\section{Resumo}

Dias, Raquel Costa; Pilatti, Adriano. A repressão criminal ao poder constituinte: as jornadas de junho de 2013 no Rio de Janeiro e o processo penal. Rio de janeiro, 2017. 137p. Dissertação de Mestrado - Departamento de Direito, Pontifícia Universidade Católica do Rio de Janeiro.

O presente trabalho destrincha a tensão entre poder constituinte e poder constituído na perspectiva das manifestações no Rio de Janeiro em junho de 2013, que são analisadas como formas contemporâneas de vivência real e prática da democracia, através da multidão, que velozmente reagia às agressões acumuladas vindas do poder constituído e dos setores interessados em manter o status quo. A multidão que foi às ruas participar dos movimentos iniciados em 2013 no Rio de Janeiro, através das redes sociais da internet, promoveu a interação e conexão de pessoas por meio dos movimentos em rede, independentemente de suas origens, ideologias ou filiações. A partir da autonomia desse espaço virtual, os movimentos sociais venceram o medo do poder constituído e lançaram-se às ruas, formaram coletivos e utilizaram-se de táticas de autodefesa. A essa parcela da sociedade contemporânea formadora da multidão de 2013 são negados os direitos da cidadania, distanciando-a dos interesses do capital e aproximando-a do conceito de inimigo. Isso ocorre especialmente quando esta se rebela contra o status quo, cuja manutenção interessa à sociedade global de controle, e que funciona simultaneamente como fomentador e como estabilizador da desigualdade, sendo esta aumentada com o incremento da repressão do Estado. A repressão violenta e desproporcional do Estado é exemplificada neste trabalho por três momentos que contribuíram para o enfraquecimento do movimento constituinte emerso das ruas em 2013, na cidade do Rio de Janeiro, marcando uma verdadeira instrumentalização da repressão à multidão: (i) a criação da Comissão Especial de Investigação de Atos de Vandalismo, através de decreto do chefe do Executivo estadual; (ii) a tramitação em regime de urgência do projeto de lei e a sanção, pela chefe do Executivo Federal, da Lei que cria o conceito de organização criminosa; e (iii) o inquérito policial que culminou com a prisão de vinte e três manifestantes cariocas às vésperas da final da Copa do Mundo no Brasil. A severa repressão dos levantes de 2013 colaborou para a manutenção do pensamento inquisitorial e para o fortalecimento de instituições autoritárias. Tal fenômeno desafia o presente trabalho a refletir sobre a viabilidade da instrumentalização do Processo Penal como meio de contenção das arbitrariedades reiteradamente cometidas contra aqueles que não se beneficiam da manutenção do status quo.

\section{Palavras-chave}

Poder Constituinte; Repressão; Jornadas de 2013; Resistência; Democracia; Processo Penal. 


\section{Abstract}

Dias, Raquel Costa; Pilatti, Adriano (Advisor). Criminal repression towards the constituent power: the June 2013 protests in Rio de Janeiro and the Criminal Procedure. Rio de janeiro, 2017. 137p. Dissertação de Mestrado - Departamento de Direito, Pontifícia Universidade Católica do Rio de Janeiro.

This work unravels the tension between constituent and constituted power in the perspective of the protests of June 2013 in Rio de Janeiro, analyzed as contemporary ways of a practical and concrete experiencing of democracy, given the spontaneity of the multitude, who rapidly reacted to the gathered aggressions that came from the constituted power and the segments interested in maintaining the status quo. The multitude that went to the streets to protest in the movements started in Rio de Janeiro, 2013, through the social media, promoted the interaction and connection of people through network movements, regardless their origins, ideologies or affiliations. From this autonomous virtual space, the social movements overcame the fear of the constituted power and went to the streets, formed collective initiatives and used self-defense tactics. Citizenship rights are denied to this part of contemporary society that formed the 2013 multitude, making it more distant from the interests of capitalism and closer to the concept of enemy. This happens specially when this multitude rebels against the status quo, whose maintenance interests the global control society, and that works simultaneously as promoter and stabilizer of inequality, which is raised by the increase of the State repression. The violent and unmeasured State repression is exemplified in this work by three moments that contributed to the weakening of the constituent movement surfaced from the streets of Rio de Janeiro in 2013. These moments marked a true instrumentalisation of the repression of the multitude: (i) the creation of the Special Commission for the Investigation of Vandalism Acts, through decree from the chief of the state Executive Power; (ii) the urgent proceeding of the bill and the sanction of the law that creates the concept of criminal organization, by the chief of the Federal Executive Power; and (iii) the police inquiry that resulted on the arrest of twenty-three carioca protestors right before the ending of FIFA World Cup in Brazil. The severe repression of the 2013 movements collaborated to maintain the inquisitorial thought and to strengthening authoritarian institutions. This phenomenon challenges this work to ponder on the viability of the instrumentalisation of the Criminal Procedure as a way of restraining the arbitrary actions repeatedly perpetrated against those who do not benefit from the maintenance of the status quo.

\section{Keywords}

Constituent Power; Repression; Brazilian 2013 Protests; Resistance; Democracy; Criminal Procedure. 


\section{Sumário}

1 Introdução

8

2 A tensão entre Poder Constituinte e Poder Constituído: inovação e resistência vs. conservação e repressão

2.1. O Poder Constituinte e sua dimensão "tumultuária": multidão, redes, levantes e manifestações

2.2. Direito Penal do Inimigo: controle e repressão - a política

criminal do poder constituído

3 2013: O levante e a repressão no estado do Rio de Janeiro

3.1. Movimentos em rede, coletivos e táticas 50

3.2. Os mecanismos legais e extralegais de repressão

56

3.2.1 A Comissão Especial de Investigação de Atos de Vandalismo CEIV

63

3.2.2. A Lei de Organizações Criminosas - Lei 12.850/2013 70

3.2.3. "Processo dos 23" 78

3.2.3.1. A prisão temporária e a prisão preventiva dos 23

3.2.3.2. O "Processo dos 23" e os mecanismos extralegais de repressão estatal

88

4 As Consequências para a Democracia 93

4.1. Os Modelos Processuais: inquisitorial e democrático 96

4.2. A Política Criminal Autoritária nas Jornadas de Junho de $2013 \quad 104$

5 Conclusão

6 Referências bibliográficas 


\section{Introdução}

As manifestações iniciadas no Brasil em junho de 2013 trouxeram ao debate constitucional formas contemporâneas de vivência real e prática da democracia, dada a espontaneidade da multidão, que velozmente reagia às agressões acumuladas vindas do poder constituído e dos setores interessados em manter a ordem vigente, que impõe a mercantilização da vida, da cultura, da arte, da política.

A par das especificidades que possuem os movimentos de 2013 quanto a sua dinamicidade, alcance, solidariedade e força política, os fenômenos ocorridos no Brasil a partir de junho daquele ano e a sua violenta repressão podem ser pensados na perspectiva do poder constituinte de Antonio Negri.

A multidão descobriu a esperança através dos mecanismos que os movimentos desenvolveram na sua vivência, consistente em um companheirismo que entende os objetivos e aspirações individuais, mas que resulta na descoberta de denominadores comuns daqueles participantes, levando em conta a necessária continuidade do movimento.

Parece-nos que a estratégia, no Brasil, foi a de criminalizar tais movimentos, de modo a dispersá-los através da indevida utilização do processo penal, com a instrumentalização progressiva de ações repressivas. Com isso, a sistemática processual penal, que poderia preencher um lugar de protagonismo dentro do sistema de garantias processuais do acusado, acaba sendo a ferramenta utilizada para permitir uma repressão violenta contra a potência constituinte que se articula e exerce o seu direito de resistência contra as camadas conservadoras que objetivam a manutenção dos privilégios. 
Sob a perspectiva do poder constituinte e sua articulação com o direito de resistência, manifestado nas jornadas de 2013, pretende-se estudar se os mecanismos de repressão criminal, legais e ou extralegais, utilizados para conter tais movimentos constituintes, ultrapassaram os limites do devido processo penal, pensado a partir de um processo penal democrático.

Compreende-se que a multidão que foi às ruas em 2013 é uma potência constituinte, que não se esgota em qualquer poder representado alheio às suas demandas, que se apresenta totalmente aberta a viver a democracia de forma plena e que se opõe ao conceito de soberania, sendo esse conceito o responsável por impor o medo objetivando a manutenção do status quo.

O processo constituinte, então embrionário, foi obrigado a recuar após a repressão, mas a potência constituinte da juventude brasileira se mostrou viva, presente no espaço público e politicamente eficiente. O seu direito legítimo de resistência contra a opressão sofrida, no entanto, encontrou barreiras na soberania do poder constituído que, à pretexto de uma legalidade autoritária e discriminatória, utilizou o sistema penal como arma letal contra os princípios democráticos reivindicados, levado a cabo a partir de criação de mecanismos específicos e aprovação de legislações penalizadoras, como, por exemplo, a Comissão Especial de Investigação de Atos de Vandalismo - CEIV e a Lei de Organizações Criminosas.

A eliminação da presença dos jovens nas ruas foi feita com espantoso êxito, mediante uma progressão de ações repressivas, que teve como marco inicial a CEIV em julho de 2013, passando pela rápida aprovação da Lei de Organizações Criminosas, aplicada em outubro do mesmo ano, encerrando com a denominada "prisão dos 23 "1 em julho de 2014, medida esta oriunda de uma investigação criminal que será analisada, especialmente quanto às peculiaridades do modus operandi da repressão criminal instrumentalizada.

Foi sob a égide da Constituição outorgada em 1937 que emergiu o Código de Processo Penal de 1941, amparado na lógica de um sistema processual penal

\footnotetext{
1 Prisão temporária de 23 pessoas, decretada nos autos da ação penal n ${ }^{\circ}$ 0022901826.2013.8.19.0001 (27 $7^{\mathrm{a}}$ Vara Criminal do Rio de Janeiro), às vésperas da estreia da Copa do Mundo no Brasil. Originada no Inquérito Policial n 1646/2013 da DRCI (Delegacia de Repressão a Crimes de Informática).
} 
inquisitório $^{2}$. Neste sistema, próprio de Estados autoritários, as garantias fundamentais do acusado são suprimidas em busca de uma "verdade real", para a qual as condutas do julgador estão voltadas, confundindo-se a sua figura com a do acusador. A sistemática inquisitorial foi posteriormente superada - ao menos formalmente - no texto da Carta Constitucional de 1988, à luz da qual iniciou-se uma releitura das normas infraconstitucionais, em conformidade com tratados de direitos humanos. A Constituição de outubro de 88 elevou, ainda, à condição de clausula pétrea os direitos e garantias individuais.

Ocorre que os mecanismos processuais penais de que dispõe o ordenamento jurídico brasileiro, no tocante à efetivação do devido processo legal, podem ter tratamento engessado dentro do sistema penal no qual é inserido, na medida em que nosso sistema processual é essencialmente inquisitório, conforme Jacinto Neto de Miranda Coutinho ensina ${ }^{3}$. Com isso, outros mecanismos manejados pelo poder constituído são pinçados como uma espécie de contenção das garantias processuais, objetivando manter a política criminal discriminatória e autoritária que, na verdade, é uma das formas de manutenção do status quo.

Faz-se necessária então a verificação dos mencionados mecanismos de repressão criminal, sejam eles legais ou extralegais, usados para repressão das jornadas de 2013 na cidade do Rio de Janeiro, bem como a observação de tais mecanismos para identificarmos em qual medida ultrapassaram os limites do devido processo penal, trazendo consequências para a democracia brasileira que formalmente optou por um sistema de proteção de direitos e garantias fundamentais.

As ações repressivas instrumentalizadas pelo Estado serão analisadas a partir de três relevantes marcos: (i) a criação, no Rio de Janeiro, da Comissão Especial de Investigação de Atos de Vandalismo - CEIV; (ii) a agilidade na tramitação de leis com viés incriminatório como a Lei de Organizações Criminosas, que entrou em vigor em setembro de 2015 e sua aplicação, em outubro, na denominada "manifestação dos professores" na cidade do Rio de Janeiro, quando mais de 60 manifestantes foram presos; e, por último, (iii) o

\footnotetext{
${ }^{2}$ A reforma do Código de Processo Penal em 1941 foi promovida pelo Ministro da Justiça do Estado Novo, Francisco Campos, influenciado pelo Código Rocco (1930), vigente no período fascista da Itália de Mussolini. Ver mais em: MALAN, 2015, p. 58.

${ }^{3}$ COUTINHO, 2001b, p. 7.
} 
processo dos 23 , iniciado em junho de 2014 , às vésperas do enceramento da Copa do Mundo no Brasil.

O estudo da CEIV foi feito através do decreto que a criou, assim como por meio de tentativas de obtenção de dados junto ao Governo do Estado e ao Ministério Público do Rio de Janeiro, órgão então responsável pela presidência da Comissão criada por Sérgio Cabral.

A Lei de Organizações Criminosas foi analisada a partir do seu trâmite legislativo no Congresso Nacional que, a partir de determinado momento em 2013, ganhou agilidade e, em outubro de 2013, já fora aplicada contra manifestantes na cidade do Rio de Janeiro, dando causa à prisão de centenas de pessoas.

$\mathrm{O}$ "processo dos 23 " e os dois inquéritos que deram origem à ação penal foram analisados sob a perspectiva do devido processo legal, com identificação de práticas da polícia e de membros do Judiciário, além da realização de entrevista em profundidade com um advogado constituído para a defesa de um manifestante (cujo anexo se encontra ao final do presente trabalho).

Essas análises, feitas a partir do ponto de vista da advocacia vonluntária nas ruas em 2013, somadas à revisão bibliográfica, permitirão identificar se mecanismos legais e extralegais de repressão criminal foram utilizados com o objetivo de pulverizar e diminuir a potência constituinte originada nas ruas em junho de 2013, bem como sua (in)adequação ao devido processo legal e possíveis consequências à democracia.

Isso porque, no lugar de se abrirem aos momentos constituintes que se multiplicavam com velocidade e força política, as instituições do poder constituído, ao contrário, se engessaram numa concepção de política criminal autoritária e inquisitorial, onde o medo imposto é o protagonista na função de manutenção do status quo. $\mathrm{O}$ medo, antes vencido pela indignação ${ }^{4}$ da multidão

\footnotetext{
4 "As sociedades são geridas com base no medo, a emoção humana mais importante. Só se supera o medo com a indignação, que permite ir além do temor de que algo lhe possa acontecer". CASTELLS, 2015. No mesmo sentido, narra Pilatti: "A indignação difusa fez com que, ali e alhures, as ruas se enchessem e as multidões pusessem de joelhos a soberba burocrática que tomava as planilhas de cálculo de "custos" como verdades absolutas e incontestáveis. Tiveram de recuar nessa e em outras questões, variáveis conforme a cidade, por força dos 'decretos da multidão' (plebiscitos, na origem romana) firmados, 'a quente' e 'a frio', nas ruas. No Rio, remoções de algumas comunidades pobres foram suspensas, e foram preservados a escola
} 
que resistia nas ruas contra a opressão diariamente sofrida, arrefeceu ânimos indignados e freou o poder constituinte da multidão que protagonizou as jornadas de junho de $2013^{5}$.

A necessidade de se discutir acerca dos mecanismos de repressão criminal das manifestações de junho de 2013 decorre então da potência transformadora que os jovens nas ruas detinham e que acabaram massacrados sob o argumento da legalidade usado pelo conservadorismo do poder constituído, a quem interessa a manutenção de um sistema político voltado aos privilégios, mesmo diante da legitimidade democrática das reinvindicações da multidão que se apresentou como verdadeiro poder constituinte.

Importante lembrar a confusão que tais movimentos, ocorridos na cidade do Rio de Janeiro, causaram, em um primeiro momento, à imprensa de veiculação em massa que, em vão, tentava identificar líderes, partidos, ideologias que dessem causa aos mesmos. Isto, a fim de os rotular, delimitar e, principalmente, minimizar, enquanto velozmente ganhavam aderência e potência política, aumentando o seu volume e alcance de forma surpreendente.

Os fenômenos de 2013 devem então ser vistos pela ótica do direito de resistência da multidão que permanentemente se articula com o poder constituinte que se coloca em oposição ao poder constituído, suscitando:

Um amplo e difuso processo de discussão através dos circuitos institucionais e virtuais de informação, que extrapolou ao controle da mídia e deu visibilidade à manipulação denunciada, como um movimento de contrapoder. A nova composição do trabalho experimentou seu constituir-se em multidão num processo veloz de composição-repulsão de forças. ${ }^{6}$

A multidão é constituinte, "é o tecido ontológico, a base material da recusa de todo tipo de teologia política, ou seja, de toda a tradição moderna da opressão que é organizada em torno da gestão do medo"”. A soberania, poder constituído, que é questionada pelo poder constituinte, é aquela que promove a hierarquização da sociedade através do medo. Na perspectiva das jornadas de 2013 no Rio de

municipal Friedenreich, o parque aquático Julio Delamare, o estádio de atletismo Célio de Barros e o edifício histórico do antigo Museu do Índio, onde acontecia potente ocupação indígena, a Aldeia Maracanã - todos eles imóveis públicos ameaçados de demolição e privatização dos respectivos terrenos." PILATTI, 2016, p. 11.

${ }^{6}$ COCCO \& PILATTI, 2013.

${ }^{7}$ Id., 2015, p. xxviii. 
Janeiro, a soberania construiu uma instrumentalidade repressiva do Estado para manter o status quo.

Acerca do conceito de multidão enquanto poder constituinte, é necessário abordar a problemática em que se encontra o conceito de poder constituinte, sobretudo no que toca às tentativas de limitá-lo, seja juridicamente, seja constitucionalmente. Neste sentido, Negri ensina que a qualificação jurídica e constitucional do poder constituinte não implica na produção de normas e estruturação de poderes, "mas sobretudo ordenar o poder constituinte enquanto sujeito, regular a política democrática" ${ }^{\text {. }}$

Negri compreende "o conceito de poder constituinte precisamente enquanto conceito de uma crise" "9. Em sua concepção, a limitação do poder constituído o aprisiona em "redes hierárquicas que articulam produção e representação", o que reconstrói o seu conceito como resultado do sistema, e não como causa ${ }^{10}$.

Destaca, neste sentido, que o problema em torno do conceito de poder constituinte não está somente na sua oposição ao poder constituído e as suas formalidades que fundamentam o conceito de soberania, mas também na sua representação ${ }^{11}$. Portanto, busca definir o poder constituinte através da ausência de determinações, como uma necessidade totalmente aberta, um procedimento absoluto e ilimitado, apresentando-se a potência constituinte como inesgotável no poder. Segundo Negri, a "práxis democrática" é propriamente movida pela ausência de pressupostos e plenitude da potência, consistente numa "atividade constitutiva transbordante, intensa como a utopia, mas sem ilusões, plena de materialidade" ${ }^{\prime 12}$.

A separação entre representação e soberania popular, que se apresentou nas ruas em junho de 2013 no Brasil demonstra a democracia radical que desvela a corrupção que igualmente separa os seus meios dos seus fins, aproveitando-se

\footnotetext{
${ }^{8}$ NEGRI, 2015, p. 1.

${ }^{9}$ Ibid., p. 2.

${ }^{10}$ Ibid., p. 14. "O poder constituinte está ligado à ideia de democracia, concebida como poder absoluto. Portanto, o conceito de poder constituinte, compreendido como força que irrompe e se faz expansiva, é um conceito ligado à pré-constituição da totalidade democrática." Ibid., p. 11.

${ }^{11}$ Ibid., p. 13.

${ }^{12}$ Ibid., p. 16.
} 
desta "aqueles que concentram os meios econômicos e a mídia, inclusive quando a condenam, de maneira moralista, apenas para aumentá-la em seu favor"13.

Nestes termos, as subjetividades da multidão constituinte das jornadas de 2013 "não abrem mão de pensar e praticar uma democracia absoluta", demonstrando o seu alcance e, acima de tudo, a limitação do poder constituído que nada pode contra eles senão utilizando-se de meios de repressão violentos na tentativa desesperada de manter o status quo.

Neste sentido, a limitação do poder constituinte ao poder constituído engessa as possibilidades de resistência da potência constituinte e suprime o nexo que historicamente liga o direito de resistência e o poder constituinte. Negri afirma que o direito de resistência é a figura ativa do poder constituinte ${ }^{15}$. Por esta razão, no pensamento moderno tradicional que limita o poder constituinte, é possível retirar da potência constitutiva o direito de resistência contra o poder constituído. É sob esta ótica que Negri afirma que "o ponto de vista do poder constituinte combate a posição contratualista e nela reconhece inevitável remissão à transcendência, ao poder constituído e à sua apologia" ${ }^{\text {, }}$, na medida que sua exigência lógica pressupõe o não poder resistir.

A questão do direito de resistência do poder constituinte contra a opressão do poder soberano que hierarquiza a soberania através do medo passa, então, pela concepção dada ao próprio poder constituinte. Ao entendermos o poder constituinte através da concepção materialista de procedimento absoluto e de democracia radical, cujo sujeito pensado por Negri "é aberto, projetado em uma totalidade sem clausura" ${ }^{, 17}$, é inevitável concluir que, para a multidão que foi às ruas em junho de 2013, outra resposta deveria ter sido dada, que não a repressão violenta e autoritária, decorrente das matrizes inquisitoriais deliberadamente mantidas pelo Estado.

Adriano Pilatti, Antonio Negri e Giuseppe Cocco, em artigo publicado no emergir da multidão, em 28 de junho de 2013, propuseram a viabilização da participação da multidão de maneira direta, através da abertura de um processo

\footnotetext{
${ }^{13}$ COCCO, NEGRI \& PILATTI, 2013.

${ }^{14}$ COCCO \& PILATTI, 2015, p. xxiv.

${ }^{15}$ NEGRI, 2015, p. 3.

${ }^{16}$ Ibid., p. 32.

${ }^{17}$ Ibid.
} 
constituinte, "ou seja, abrir a pólis à participação efetiva do demos, para além das ruas, a fim de unir o movimento e suas inovações" $"$.

A ausência de abertura política para o exercício da democracia efetiva veio à tona. Em que pese a Presidenta Dilma Rousseff ter declarado, na ocasião, que "tinha a obrigação de escutar a voz das ruas"19 e, em um primeiro momento, ter sido exitosa a soberania popular quanto à demanda na redução das tarifas do transporte público, os movimentos que continuaram nas ruas pós junho de 2013, com demandas pela democracia material e igualdade de direitos, foram eliminados do seu "espaço de autonomia" através de verdadeira batalha persecutória do Estado contra seus "novos inimigos". Através de mecanismos de repressão progressivamente instrumentalizados, o Estado responde institucionalmente, operando na linha da exceção e do controle do inimigo ${ }^{20}$.

O fechamento do diálogo do poder constituído em relação ao poder constituinte pode ter origem na potência constitutiva que a multidão demonstrou ter ao obter êxito com a demanda das tarifas de transporte público. Essa “inovadora interação entre a política nas ruas e a política nas instituições"21 apavorou os setores conservadores da política instituída, fazendo o processo constituinte recuar através da repressão e do controle.

A resistência contra a opressão da soberania usurpadora do poder constituinte é legítima da multidão e faz parte do exercício da democracia radical. Deve, portanto, ser amplamente exercida e incluída no procedimento aberto de uma constituinte, na tentativa de novo delineamento de uma outra ordem possível.

É questão de reconhecer e dar combate às iniciativas imperiais e não lhes permitir que restabeleçam a ordem continuamente; é questão de contrariar e subverter os limites e segmentações impostos à nova força coletiva de trabalho; é questão de

\footnotetext{
18 “Se o governo e o PT acharem que poderão evitar essa abertura pela mobilização de supostos representantes de casas e circuitos, repetirão o mesmo erro que fez Haddad quando acreditava que existia amor em São Paulo. O poder constituinte não é nada sem a multidão que o faz viver." COCCO, NEGRI \& PILATTI, 2013.

19 ROUSSEFF, Dilma. Pronunciamento, 21 jun. 2013. Disponível em: $<$ http://www2.planalto.gov.br/acompanhe-o-planalto/discursos/discursos-dapresidenta/pronunciamento-da-presidenta-da-republica-dilma-rousseff-em-cadeia-nacional-deradio-e-tv>. Acesso em: 3 jun. 2017.

${ }^{20}$ HARDT, 2000, p. 2.

${ }^{21}$ CASTELLS, 2013, p. 181.
} 
reunir esses instrumentos de resistência e empunhá-los de comum acordo contra os centros nervosos do comando imperial. ${ }^{22}$

O direito de resistência da multidão contra a opressão da soberania constituída só encontra eficácia quando o poder constituinte é compreendido na sua concepção materialista, que compreende o absoluto da democracia radical. Caso contrário, faz-se vencido pelo medo imposto através das reações autoritárias do poder constituído que apreende o constituinte através da concepção transcendental da soberania. Neste caso, pode-se reprimir e controlar até que o medo vença.

E foi precisamente o medo, articulado com outras ferramentas de repressão progressivamente instrumentalizadas com pretensão de controlar a potência constituinte, que serviu como barreira usada pela soberania do poder constituído que, à pretexto de uma legalidade autoritária e discriminatória, esvaziou paulatinamente as ruas até julho de 2014 , tendo como marco definitivo a prisão $\operatorname{dos} 23$.

É, pois, a partir da perspectiva do poder constituinte, no tocante à resistência ao controle e à repressão, que devem ser estudados os mecanismos legais e extralegais utilizados pelo sistema penal contra o movimento constituinte, que objetivou conter a sua potência emergente das jornadas de 2013. A construção de uma instrumentalidade progressiva do Estado em ações repressivas, que protege a soberania constituída, compreendida em sua concepção transcendental, em detrimento da concepção materialista da soberania ensinada por Negri, deverá então ser analisada em confronto com um processo penal democrático, que identifica uma política criminal voltada à manutenção do status quo.

\footnotetext{
${ }^{22}$ HARDT \& NEGRI, 2001, p. 423.
} 


\section{A Tensão entre Poder Constituinte e Poder Constituído: inovação e resistência vs. conservação e repressão}

A combinação de desigualdades de classe com a delegação do exercício do poder aos representantes constituídos é o desencadeador da crise de legitimidade da representação na medida em que o poder constituinte se identifica pouco, ou nada, com as demandas atendidas pelo poder constituído que, em regra, estão a serviço do poder econômico. Essa crise, e, somando-se a ela, as incessantes negações de direitos, descola esses dois poderes, bem como desloca o poder constituído para a abstração da soberania, possibilitando a sua corrupção, ocorrida quando há essa separação entre fundamento e resultado ${ }^{23}$.

Tal separação, no Brasil, deu ensejo aos levantes de 2013, iniciados, primeiramente, com reivindicações específicas, como o aumento das passagens de ônibus, ganhando posteriormente pautas relativas ao acesso das populações excluídas pelas instituições públicas.

A perspectiva constituinte abordada neste trabalho assume, então, o caráter necessariamente crítico da política, compreendendo-a "como crise e dissenso, como tensão entre a resistência, a insurgência e a capacidade de inovação dos movimentos" dos deslocados ante as "estratégias de contenção, captura e neutralização desenvolvidas pelos poderes constituídos nas sociedades de classe" 24 .

\footnotetext{
${ }^{23}$ PILATTI, 2016b, p. 1. A relação entre poder constituinte e poder constituído "poderia ser concebida como uma relação entre fundamento e resultado". CORRUPÇÃO: "duplo mecanismo de corrupção da democracia: a concentração perversa de poder econômico e a inversão da relação entre poder constituído (os representantes) e poder constituinte (o demos)."

${ }^{24}$ Ibid.
} 
O poder constituinte não é somente a fonte da produção de normas constitucionais dos ordenamentos jurídicos, como o pensamento moderno e constitucionalista assim definiu, mas, sobretudo, o sujeito dessa produção ${ }^{25}$, como pensa Negri, no sentido de que "qualificar constitucionalmente e juridicamente o poder constituinte não será simplesmente produzir normas constitucionais e estruturar poderes constituídos, mas sobretudo ordenar o poder constituinte enquanto sujeito" 26 .

Ao se identificar com o conceito de política ${ }^{27}$, o conceito jurídico do poder constituinte é encontrado em meio a uma crise decorrente da sua natureza híbrida, consistente, ao mesmo tempo, na resistência que a potência ocultada pelo poder constituinte apresenta contra a constitucionalização ${ }^{28}$ e no fato de que a democracia - considerada como teoria do governo absoluto - se contrapõe ao constitucionalismo, que é visto como teoria do governo limitado. Ou seja, a democracia também resiste ao constitucionalismo porque, em síntese, este significa, na prática, a limitação daquela ${ }^{29}$.

$\mathrm{Na}$ perspectiva da ciência jurídica, o poder constituinte é a fonte de produção das normas constitucionais, é "o poder de fazer uma constituição e assim editar as normas fundamentais que organizam os poderes do Estado". Esse conceito desafia Negri a defini-lo como um paradoxo que, por seu caráter extremo, é insustentável: "um poder que surge do nada e organiza todo o direito". Com efeito, considerar o poder constituinte como um acontecimento extraordinário é limitá-lo temporalmente, detendo-o em categorias jurídicas e submetendo-o a uma rotina administrativa, subtraindolhe o tempo que é próprio do poder constituinte, “dotado de uma formidável

\footnotetext{
${ }^{25}$ A articulação entre sujeito e estrutura feita por Negri e Hardt sugere a compreensão da relação entre multidão e democracia, na medida em que o sujeito constituinte é a multidão, de modo que a estrutura é a própria democracia que, na proposta de Negri, corresponde à ação da multidão como poder constituinte de um governo que é de todos e não de muitos. "Somente na multidão enquanto capaz de expressão de trabalho vivo, está a verdade da constituição. A democracia, uma democracia real, no direito e na apropriação, com igualdade na repartição da riqueza e participação na produção, torna-se o Deus vivo - nele se identificam o sujeito e a estrutura, a potência e a multidão.” NEGRI, 2015, p. 319.

${ }^{26}$ Ibid., p. 1.

${ }^{27}$ No sentido com que esse é compreendido em uma sociedade democrática. Ibid.

28 "A potência que o poder constituinte oculta é rebelde a uma integração total em um sistema hierarquizado de normas e de competências...". BURDEAU apud NEGRI, op. cit., p. 1.

${ }^{29}$ Ibid.
} 
capacidade de aceleração, tempo de acontecimento e da generalização da singularidade" ${ }^{, 30}$.

Negri identifica um presumido círculo vicioso consistente na absorção da ideia de poder constituinte como formador do direito pela ideia de representação política para legitimação do conceito de poder constituinte. Um círculo vicioso, porém, que não pode então ser interrompido sem que venha à tona a contradição entre a eficácia onipotente e expansiva do poder constituinte e o sistema de normas positivas do poder constituído, fazendo com que, de alguma forma, seja mantido o conceito de poder constituinte, "para evitar que sua eliminação leve consigo o próprio sentido do sistema jurídico e a referência democrática que lhe deve qualificar o horizonte" ${ }^{\text {, }}$.

A ciência jurídica, então, segundo Negri, criou formas de encerrar o poder constituinte em um mecanismo jurídico com vistas a controlar seus efeitos e os valores que exprime. São três soluções dadas por juristas e consideradas por Negri, cada uma dando enfoque à transcendência, imanência ou integração do poder constituinte em relação ao sistema jurídicoconstitucional e ao poder constituído ${ }^{32}$.

A posição tradicional considera o poder constituinte como fonte transcendente ao poder constituído, entendendo que o poder constituinte é um fato que precede e funda o ordenamento constitucional, "mas o faz por meio de um nexo causal imediatamente rompido, de modo que a autonomia do ordenamento jurídico constituído é absoluta" ${ }^{, 33}$. Outra orientação para solucionar a crise do poder constituinte é considerá-lo como imanente ao sistema jurídico-constitucional, que torna o poder constituinte um "autêntico motor da dinâmica constitucional” aceito pela ciência jurídica, de modo que a

\footnotetext{
${ }^{30}$ NEGRI, 2015, p. 2.

${ }^{31}$ Ibid. Mas se o caráter onipotente do poder constituído "obriga" a sua limitação temporal através da sua percepção como um acontecimento extraordinário, também busca-se limitar a sua expressão espacial, na medida em que "sua expansividade não deve se manifestar a não ser... dentro de limites e procedimentos bem definidos... Uma fortíssima parafernália jurídica cobre e desnatura o poder constituinte." Ao se subtrair do poder constituinte a sua figura ativa, consistente no direito de resistência, o poder constituinte em sentido próprio, assemblear, distinguiu-se do poder constituinte originário, tendo sido este absorvido pelo conceito de nação. Contudo, o poder constituído opõe-se aos dois, absorvendo a expressão constituinte através das regras do sufrágio, das regras parlamentares, delimitando-a "mais próxima à forma da ditadura clássica do que à teoria e às práticas da democracia".

${ }^{32}$ Ibid., p. 4.

33 "Pouco ou nada resta do poder constituinte após essa operação de fundação formal do direito e, portanto, de redução ética (como em Jellinek) ou sociológica (como em Kelsen) do seu conceito." Ibid., p. 5.
} 
imanência pode ser estabelecida em um grau mínimo ou máximo de incidência ${ }^{34}$. No entanto, sempre haverá mecanismos de neutralização do poder constituinte ${ }^{35}$.

A última posição teórica indicada por Negri como disposta a solucionar o paradoxo entre o poder constituinte e o sistema jurídico-normativo por meio do qual o poder constituído atua, é aquela que "considera o poder constituinte como integrado, constitutivo, coextensivo e sincrônico ao direito constituído" 36 , que fora assumida posteriormente pela dogmática jurídica e diferencia "constituição formal" de "constituição material". "A elasticidade da constituição formal é delimitada pelas forças que constituem politicamente a sociedade e formam sua constituição material por meio de compromissos institucionais contínuos" ${ }^{, 37}$, de modo que a constituição material é o que dá os moldes da constituição formal, pautando a sua interpretação, modificação e eventuais substituições. O que está na base constitucional é um movimento constante que determina seu dispositivo, e não uma norma fundamental ${ }^{38}$.

Todas as formulações teóricas da ciência jurídica e, por meio desta, o ordenamento constituído, que tratam da relação problemática entre o poder constituinte e o poder constituído, acabam, entretanto, esvaziando a política que se constitui nos cenários da potência da multidão e a ligação íntima e contínua do poder constituinte com a democracia ${ }^{39}$.

O problema na perspectiva do direito público é, então, insolúvel, de modo que, sob a perspectiva do constitucionalismo, a análise do poder constituinte desmascara toda pretensão soberana, na medida em que o constitucionalismo se apresenta "limitado pelo controle jurisdicional dos atos administrativos e sobretudo pela organização do poder constituinte pela lei”.

\footnotetext{
${ }^{34}$ O grau mínimo de incidência do princípio constituinte como imanente ao poder constituído, representado pelas formulações de John Rawls, trata da "reabsorção do poder constituinte pelo direito constituído por meio de uma máquina de vários estágios que, tornando o poder constituinte imanente ao sistema, tolhe sua originalidade". Considerando as posições teóricas em que o grau de imanência do poder constituinte é mais forte, "a vigência normativa da constituição jurídicoformal depende do grau de adequação entre as ordens de realidade (material e formal, sociológica e jurídica) que foi estabelecido pelo poder constituinte. Este é um poder de formação em sentido próprio. A sua extraordinariedade é pré-formadora, a sua intensidade estende-se, como projeto implícito, pelo conjunto do ordenamento." NEGRI, 2015, p. 10.

${ }^{35}$ Ibid., p. 6.

${ }^{36}$ Ibid., p. 9.

${ }^{37}$ Ibid., p. 10.

${ }^{38}$ FORSTHOFF, 1964 apud NEGRI, op. cit., p. 10.

${ }^{39}$ Ibid., p. 10.
} 
Nesse sentido, o poder constituinte como poder último é legitimado e expresso através de um procedimento legal, mas de maneira que essa legitimação não se justifica pela obediência ${ }^{40}$, "mas pelo seu modo de expressão jurídica, modo este cuja formalização garante o poder constituinte do povo [...] Pois a constituição não é um ato de governo, mas um ato de povo." 41 .

O poder constituinte é identificado por Negri como signo de uma expressão radical da vontade democrática da multidão, considerando a práxis do poder constituinte a porta pela qual essa vontade entrou no sistema político, levando junto a questão social e, assim, destruindo o constitucionalismo cujo paradigma não é democrático, uma vez que "o paradigma constitucionalista é sempre o da 'constituição mista', da mediação da desigualdade e na desigualdade" ${ }^{\prime 42}$.

Em oposição ao paradigma constitucionalista, o paradigma do poder constituinte está ligado à ideia de democracia concebida como poder absoluto. É o paradigma de "uma força que irrompe, quebra, interrompe, desfaz todo equilíbrio preexistente e toda continuidade possível”"43. Para Negri, a dimensão de poder absoluto "entra em choque com o constitucionalismo de forma direta, forte e duradoura" 44 .

A luta entre democracia e constitucionalismo e entre o poder constituinte e a práxis dos limites da democracia, torna-se "cada vez mais presente à medida em que a história amadurece seu curso". Negri explica que o poder constituinte se forma incessantemente em todo lugar e que é vã a pretensão do constitucionalismo de limitar sua temporalidade dentro de uma regulação jurídica que tem como referência o tempo já transcorrido: “o poder constituinte é (...) uma vontade absoluta que determina o seu próprio tempo" $" 45$.

\footnotetext{
${ }^{40}$ NEGRI, 2015, p. 10.

41 “'(...) não existem 'fatos normativos': nem como poder constituinte baseado em uma forma que consegue fazer obedecer, nem como constituição material realizada por meio da classe política". MATTEUCCI, 1987 apud NEGRI, op. cit., p. 11.

${ }^{42}$ Ibid., p. 11.

${ }^{43}$ Ibid.

${ }^{44} \mathrm{Ibid}$.

${ }^{45}$ Ibid., p. 12. No mesmo sentido: "A partir da Revolução Humanista do século XIV a modernidade se configurou como momento histórico de liberação com relação ao passado, como fundação de um novo tempo e, inclusive, de uma nova compreensão da própria temporalidade. (...)
} 
A crise do conceito de poder constituinte é mantida sob o viés constitucionalista porque, segundo Negri, o tempo de um nada tem a ver com a temporalidade do outro, isto é, são antagônicos: o movimento do poder constituinte versus a inércia e tradição do constitucionalismo. A crise do conceito também se mantém sob o viés da representação, vez que suspeita de conter "um elemento de continuidade com o constitucionalismo" 46.

A crise da modernidade (imanência vs. transcendência) abriu espaço para a hegemonização da transcendência com a finalidade de conter a liberdade da imanência, do mesmo modo em que o poder constituído pela transcendência buscou diversas maneiras de conter o movimento constituinte, afirmando o seu poder através da soberania ${ }^{47}$.

É então que Negri propõe que o poder constituinte seja compreendido justamente a partir da ausência de síntese na tensão existente entre poder constituinte e poder constituído, proposta essa que, uma vez aceita, significa "negar que o conceito de poder constituinte possa ser fundado"48. Para o autor, a tentativa de limitar o poder constituinte é insustentável, "mas a tentativa de bloqueá-lo por meio de uma prefiguração finalística torna-se imediatamente inconcebível: pode-se, de fato, buscar limitar a amplitude do evento, mas por certo não é possível definir antecipadamente sua singularidade inovadora" 49 .

Tais limitações que tentam definir e concluir o poder constituinte o retém em redes hierárquicas que o submetem a um conceito de resultado do sistema constituído e não como sua causa, evocando a soberania e colocandoa como fundamento em oposição ao poder constituinte. Em outras palavras, poder constituinte e soberania estão em posições antagônicas a todo tempo e, como consequência, o caráter absoluto que ambos aspiram, "pois o caráter

\footnotetext{
O tempo passa a indicar registro da produção do novo, da criação, da expressão de uma certa essência singular." Ver mais em: GUIMARAENS, 2002, p. 81.

${ }^{46}$ Representação "como um dos instrumentos jurídico-constitucionais fundamentais para o controle e a segmentação do poder constituinte". NEGRI, 2015, p. 13. "Afirmar a representação como meio necessário de expressão do poder constituinte é defender a estrutura constituída de divisão social do trabalho, aquela mesma estrutura, (...) que entende a plebe como coletividade passional e incapaz de exercer o poder em qualquer circunstância." Ver mais em: GUIMARAENS, op. cit., p. 96.

${ }^{47}$ GUIMARAENS, op. cit., p. 86.

${ }^{48}$ NEGRI, op. cit., p. 13-14.

${ }^{49}$ Ibid., p. 14.
} 
absoluto da soberania remete a um conceito totalitário, enquanto o caráter absoluto do poder constituinte remete ao governo democrático" ${ }^{, 5}$.

Enquanto que, para Negri, "limitar o poder constituinte significa limitar a democracia",51, deve-se considerar o poder da multidão de fazer história em um processo de construção democrática radical que marca uma "outra modernidade" que não a do capital. Negri fala da "modernidade do poder constituinte, que a dinâmica da acumulação - com sua 'dialética perversa que imbrica virtù e fortuna', trabalho e capital, nunca conseguirá 'aprisionar', ${ }^{\prime 52}$.

Os filósofos políticos modernos que buscavam definir qual a melhor forma de governo no fim do século XVIII e no início do XIX, período que marca o fim do Estado Absoluto, iniciaram teorias de controle e limitação do poder constituinte através do constitucionalismo, objetivando, como já mencionado, o poder constituído. Não obstante, as constituições do Estado Moderno no século XIX, e a constituição do trabalho como seu elemento central de definição, abriram uma alternativa imanente, caracterizada pela abertura contínua e renovada do poder constituinte, fundamentando o pensamento democrático ${ }^{53}$. "Nessa tradição, a ausência de pré-constituições e de finalidades combina-se com a potência subjetiva da multidão" ${ }^{54}$, que constitui o social como uma potência baseada na ausência, de modo que o desejo nutre o movimento da potência, enquanto o constitucionalismo distanciava o social da política, fazendo com que esta fosse identificada como o próprio Estado. A racionalidade da filosofia política moderna instrumentaliza a repressão, na medida em que angustia por uma ordem estabelecida pelo medo. "O moderno é, assim, a negação de que a multidão possa se exprimir como subjetividade"

Entretanto, já no início do século XVI, Maquiavel enfrentou o tema de controle do poder constituído, o que compreendeu ser possível através das três formas de governo que mantinham uma tensão produtiva ${ }^{56}$. Negri recorre à

\footnotetext{
${ }^{50}$ NEGRI, 2015, p. 14-15.

${ }^{51}$ Ibid., p. 8.

${ }^{52}$ Ibid., p. 125.

${ }^{53}$ Ibid., p. 240.

${ }^{54}$ Ibid., p. 15.

${ }^{55}$ Ibid., p. 338.

${ }^{56}$ GUIMARAENS, 2002, p. 88.
} 
Maquiavel $^{57}$ para explicar o seu conceito de poder constituinte. E, em que pese não tenha nomeado de poder constituinte, Maquiavel enfrentou a questão do controle pelo poder constituído sem, contudo, afastar a questão social da política, como fizeram os filósofos modernos cerca de dois séculos depois. Ao contrário, por meio do seu entendimento de que o Estado deve buscar equilíbrio entre as três formas de governo (monarquia, aristocracia e democracia), Maquiavel valoriza a tensão existente entre tais formas, especialmente quando contrapõe fortuna e virtù que, naturalmente, evoca as origens do poder constituinte e defende a resistência a tudo que é externo à ação humana: "a virtù se apresenta como força coletiva de constituição de mecanismos de resistência às vicissitudes da fortuna, de modo que as coletividades possam evitar determinações externas a si mesmas" ${ }^{\text {. }}$.

Resistir à transcendência é resistir ao que é considerado externo à ação humana, de modo que a virtù persevera no ser, é um movimento de produção de vida. Diferentemente, tudo o que depende da fortuna é incerto, não cabendo qualquer ingerência em seus desígnios, de modo que o seu poder só se manifesta onde não há resistência, sendo a sua violência direcionada para onde não existe resistência organizada. A virtù opera, então, na noção de total imanência, sem qualquer registro de transcendência, possuindo uma dinâmica interna associada à ideia de modificação necessária e contínua: uma conservação no movimento, uma prática ininterrupta, constitutiva e concreta. Deve, portanto, ser vista sempre de um modo atual, resistente à fortuna, sem vínculo a qualquer modelo transcendente ideal ${ }^{59}$.

A concretude desta prática, em Maquiavel, é apresentada na forma da República, na medida em que a contemporaneidade do filósofo mostrava que "o modo de ser republicano era um meio de resistência e de afirmação de um novo projeto com relação às estruturas de poder" ${ }^{\circ 0}$. O real republicano e virtuoso de Maquiavel desfaz, portanto, a ordem constituída no

\footnotetext{
${ }^{57}$ Negri não recorre apenas a Maquiavel para fundamentar o seu conceito de poder constituinte, mas também às concepções de Spinoza e de Marx. Os três filósofos de teorias imanentes, que desacreditam em qualquer possibilidade de conciliação entre o plano transcendente e o plano imanente, dão à Negri fundamento para avançar e pôr a sua visão a respeito da potência da multidão constituinte, especialmente ultrapassando algumas limitações que os referidos filósofos modernos impunham à definição de multidão.

${ }^{58}$ GUIMARAENS, 2002, p. 126.

${ }^{59}$ Ibid., p. 127.

${ }^{60}$ Ibid., p. 128.
} 
estabelecimento de privilégios e constitui uma nova sob a premissa de que "o povo é mais sábio e constante do que o príncipe", não fazendo sentido afirmar, com base no argumento de que determinadas pessoas têm mais aptidão para governar que outras, que a multidão deve ser controlada. Ao contrário, Maquiavel afirma que a virtù se apresenta mais forte coletivamente do que individualmente, rejeitando, em defesa da liberdade, qualquer possibilidade de transcendência e estabelecendo a virtù como uma atividade que constitui resistência, na medida em que esta é expressa através da experiência republicana ${ }^{61}$.

Maquiavel introduz o conceito de mutação relacionado às ações constitutivas de poder, na medida em que o tempo é a "matéria de que são constituídas as relações sociais" ${ }^{\prime 62}$ : é a experiência acumulada pelo povo nos conflitos, uniões e desuniões que reconfigura as relações em caráter contínuo, compondo uma estrutura histórica dissociada do destino, do passado e da continuidade. "A realidade afirma-se como a mais alta pulsação de inovação e vida... A verdade é constitutiva." 63 .

O núcleo fundamental do conceito de poder constituinte, segundo Negri, é a tensão entre imanência e transcendência, tensão a respeito da qual Maquiavel foi o primeiro a aprofundar e, por conseguinte, inaugurar o conceito de poder constituinte como aquele que não deve ser mediado pelo poder constituído e como aquele em movimento contínuo de singularidades motivadas pela liberação.

É, portanto, da ausência de determinações e como uma necessidade totalmente aberta, que emerge a definição do poder constituinte de Negri, não se esgotando nunca no poder, uma vez que a multidão não se torna totalidade, mas um conjunto de singularidades. A tensão entre a imanência do poder constituinte e a transcendência do poder constituído não se resolve, como se explicou, por meio de uma composição ou agenciamento das singularidades. É bem mais complexo que isso e, partindo de tal complexidade, o presente trabalho objetiva justamente destrinchar essa tensão sob uma perspectiva do poder constituinte imanente e constante, representado sob a forma de

\footnotetext{
${ }^{61}$ GUIMARAENS, 2002, p. 130.

${ }^{62}$ NEGRI, 2015, p. 43.

${ }^{63}$ Ibid., p. 43-44.
} 
multidão, mas massacrado e reprimido em nome da alegada necessidade de manutenção, à força, do poder constituído transcendente.

Quando os excluídos decidem tomar parte do que lhes é negado riqueza social e direção na política - e, “aspiram a ser o todo numa sociedade sem partes, instaura-se um desentendimento fundamental que qualifica propriamente a dimensão da política" ${ }^{64}$, diferenciando-a da atividade de mera polícia da pólis. Essa tomada de decisão por parte das classes subalternas é denominada por Negri de lutas desestruturantes e lutas constituintes.

As lutas desestruturantes ocorrem quando as classes subalternas se recusam a ser "parte dos sem parte", o que fazem através de "desobediência civil, sabotagem, lutas salariais de desestabilização da estrutura produtiva, lutas pontuais, contestação das formas de comando etc., contra a democracia como forma de governo"65. As lutas constituintes são aquelas motivadas pela recusa de ser parte e pela aspiração de ser o todo, consistindo em lutas "em favor de uma democracia do comum, que desenvolve formas de organização autônoma, de autogestão coletiva, um exercício democrático do comum etc." 66 . As duas dimensões podem, no entanto, ser simultâneas nas insurgências constituintes de resistência e inovação: "lutas desestruturantes contra a corrupção do poder constituído e lutas constituintes em prol de uma outra democracia" ${ }^{\circ 7}$.

\section{1}

O Poder Constituinte e sua dimensão "tumultuária": multidão, redes, levantes e manifestações

A dimensão tumultuária do poder constituinte consiste na sua capacidade contínua de mudança em busca da liberdade, em permanente resistência ao poder constituído, o que foi melhor explicado por Maquiavel no

\footnotetext{
${ }^{64}$ NEGRI, 2015, p. 43.

${ }^{65}$ PILATTI, 2016b, p. 2.

${ }^{66}$ Ibid.

${ }^{67}$ Ibid. No mesmo sentido, afirma que: “(...) duplo mecanismo de corrupção da democracia: a concentração perversa de poder econômico e a inversão da relação entre poder constituído (os representantes) e poder constituinte (o “demos").” Ibid., p. 13.
} 
sentido de que o conflito social é a base do poder republicano, interessandolhe a crise do princípio constituinte e não a sua solução.

Ou seja, os tumultos e os conflitos sociais é que dão origem à "boa ordem" em Maquiavel, o que sustenta o conceito de Negri de que o poder constituinte não é perpétuo, mas sim de que há mudança e subversão, na medida em que a "boa ordem" é alcançada com o tumulto do dissenso de uma sociedade dual, entre virtù e fortuna.

Negri enxerga o paradigma maquiaveliano ${ }^{68}$ como uma multidão em constante movimento, que é mais sábia que o príncipe, razão pela qual o povo sempre merecerá mais credibilidade. Para o autor, Maquiavel exalta a juventude e sua capacidade "de ser a força da multidão na construção da glória"69, reiterando a legitimidade do governo da multidão e indicando a democracia como melhor forma de governo. Após definir o sujeito como entidade coletiva, Maquiavel indica a necessidade de dar efetividade a esse sujeito, mais especificamente como potência na dinâmica da produção. É aí que Negri identifica, ao relembrar da crise inconciliável entre virtù e fortuna, que a virtù neste caso está à frente, emanando de uma vida voltada para o bem comum, "e esse bem comum não é perseguido a não ser em repúblicas"70.

A leitura que Negri faz do Livro III dos Discorsi é fundamental para o conceito de multidão aqui utilizado, mais especificamente no tocante à "forma constitucional da multidão" a partir do aperfeiçoamento da virtù, "que passa da experiência da objetividade à experiência das paixões; rearticula, internamente, virtù e efetividade e, pela base, os dispositivos que geram o processo constituinte" ${ }^{\text {71 }}$. Maquiavel é um entusiasta da reforma da Renascença $^{72}$ ao buscar um sujeito coletivo que seja capaz de se opor à acumulação da fortuna em favor da acumulação da virtù, de modo que não haja conciliação dos antagonismos entre os dois, mas sim que a virtù ocupe o

\footnotetext{
${ }^{68}$ Referindo-se ao último capítulo do Livro I da Discorsi de Maquiavel.

${ }^{69}$ NEGRI, 2015, p. 74.

${ }^{70}$ Ibid., p. 75.

${ }^{71}$ Ibid., p. 82.

${ }^{72}$ A Renascença significava a redescoberta da liberdade e da produção, bem como a descoberta da capacidade de acumulação. Para Maquiavel, significava a capacidade da virtù de construir e inventar (liberdade e produção) e, por outro lado, antagonicamente, isso proporcionava uma acumulação através da qual construía-se a fortuna que, por sua vez, opunha-se à virtù. É contra essa dialética perversa que Maquiavel busca fortalecer a acumulação da virtù e não da fortuna, o que propõe através da criação de um sujeito coletivo que se oponha a esse processo. Cf. NEGRI, op. cit., p. 82.
} 
lugar da fortuna através de um governo da multidão, na forma de democracia. A solução proposta por Maquiavel para evitar a neutralização da virtù neste contexto é um tanto ambígua justamente em razão da experiência das paixões, passando pela possibilidade de repressão e punição exemplar, como adiante melhor será abordado ${ }^{73}$.

Mas o caráter tumultuário da multidão fica evidente quando Maquiavel estabelece uma constante da república: a sua decadência. Se na república há sempre desunião, sobre estas estão as paixões que geram as desordens e, por conseguinte, a ruína. Neste sentido, na república não existe perpetuidade, mas a sua possibilidade de renovação e reforma é, sim, perpétua. Eis a dimensão tumultuária do poder constituinte, que tem a capacidade de, através da desordem, promover a boa ordem ${ }^{74}$.

Negri também recorre a Spinoza para construir o seu conceito de multidão, no sentido de que o filósofo prevê a natureza monstruosa da multidão, com uma capacidade de transformação pelo desejo, pela liberação. Na mesma linha, Paolo Virno coloca que multidão, no contexto spinoziano, é sinônimo de uma "pluralidade que persiste como tal na cena pública, (...) sem convergir no Uno, sem evaporar-se em um movimento centrípeto. A multidão é a forma de existência política e social dos muitos enquanto muitos: forma permanente." 75 .

A ação política da multidão (virtuosismo político ${ }^{76}$ ), para autores como Virno, é viabilizada mediante a desobediência civil radical, que não significa a recusa no cumprimento de uma norma que, por exemplo, viole a constituição ou outra norma, pois tal conduta ratifica a lealdade ao comando do Estado, mas sobretudo em uma ação de digressão, como forma de resistência da multidão, questionadora das ordens estatais. Com isso, para Virno, “a desobediência radical 'precede às leis civis', já que não se limita a

\footnotetext{
${ }^{73}$ NEGRI, 2015, p. 82.

${ }^{74}$ Ibid., p. 84.

${ }^{75}$ VIRNO, 2013, p. 9

76 'Não se trata, porém, de 'alcançar o poder', de construir um novo Estado, um novo monopólio da decisão política, mas de defender as experiências plurais, as formas de democracia nãorepresentativa, usos e costumes, não-estatais. Quanto ao resto, não é difícil ver as diferenças: a multidão atual tem como pressuposto um Uno não menos, senão que mais universal que o Estado: o intelecto público, a linguagem, os "lugares comuns" (pensar na web...). Além disso, a multidão contemporânea leva em si a história do capitalismo, acha-se ligada duplamente às vicissitudes da classe trabalhadora.". VIRNO, op. cit., p. 27.
} 
violá-las, mas que coloca em causa o fundamento mesmo de sua própria validade" ${ }^{, 77}$.

A partir da desobediência radical, Virno contempla uma outra forma de exercício da virtude política por parte da multidão: o êxodo, no sentido de defecção, ou seja, como abandono de uma obrigação ou compromisso impostos. Não se trata de simples omissão, mas "consiste em uma invenção desrespeitosa que altera as regras do jogo e enlouquece a bússola do adversário" 78 .

Para Virno, entre as duas opções de ação política da multidão, "opçãoresistência" ou "opção-fuga", a primeira é preterida em favor da segunda, que, com toda certeza, não se trata de fuga a uma fronteira espacial, mas "a soma de saberes, comunicações, atuações virtuosísticas de conjunto implicadas na publicidade do general intellect"79, para a qual a defecção dá abrangência afirmativa e autônoma, impedindo que esta soma seja 'transferida' ao poder estatal, ou sua apropriação pelo capital" 80 .

A multidão baseia-se na multiplicidade e heterogeneidade de um sujeito coletivo, na medida em que a sua potência constitutiva emana das suas singularidades, sem impedir que o sujeito coletivo colabore para um agir em comum $^{81}$. "O princípio do caráter absoluto do poder constituinte é o princípio da multidão em ação" ${ }^{\text {" }}$. A partir desta dimensão tumultuária do poder constituinte existente ante o seu movimento contínuo em busca de mudança, a multidão é aqui compreendida através da definição trazida por Antonio Negri, sendo aquela consistente na multiplicidade de subjetividades que age de acordo com o que as singularidades têm em comum. "É um sujeito social internamente diferente e múltiplo cuja constituição e ação não se baseiam na

\footnotetext{
${ }^{77}$ VIRNO, 2013, p. 52.

${ }^{78}$ Ibid., p. 53.

79 Ibid.

${ }^{80}$ Ibid. "É a cooperação social como tarefa concertada, conjunto de relações poiéticas, cognitivas, emotivas. É o general intellect, o intelecto geral, objetivo, extrínseco. A multidão contemporânea está composta de indivíduos individuados, que levam à suas costas também esta realidade préindividual (além de, naturalmente, a percepção sensorial anônima e a língua, de todos e de ninguém)."

${ }^{81}$ HARDT \& NEGRI, 2004, p. 146.

${ }^{82}$ NEGRI, 2015, p. 86. "O poder constituinte funda a cidade e faz-se representar sempre como atividade por meio da milícia, a fim de que o cansaço e a inércia não suprimam a liberdade."
} 
identidade ou unidade (nem muito menos na indiferença), mas naquilo que têm em comum" $" 83$.

A multidão também é, segundo Negri e Hardt, uma rede aberta em contínua expansão, na qual as singularidades e subjetividades são expressadas e há meios de convergência para o comum ${ }^{84}$. Nessa perspectiva, as multidões se relacionam com outras multidões dando vida à multidão: o comum que constitui esse processo também é o que dá flexibilidade e mobilidade à multidão ${ }^{85}$. O amadurecimento dessa vivência permite a tomada de decisão política pela multidão, assim como acontece na produção do comum. Essa tomada de decisão, segundo Hardt e Negri, se dá por meio de suas redes de comunicação e cooperação ${ }^{86}$, onde também se produz o comum. É neste contexto em que deve acontecer a ruptura para criação do novo.

A rede, explicada por Negri como uma nova forma de organização do comum, definindo o seu agir no mundo, está, segundo o autor, presente em diversos setores como, por exemplo, nos movimentos sociais, no empresariado, nas relações pessoais e até em organizações militares. O autor explica que as redes assumiram a forma que tende a organizar e definir como compreendemos e agimos no mundo. Neste contexto, as redes organizam as relações cooperativas e comunicativas determinadas pelo paradigma da produção imaterial $^{87}$.

Numa perspectiva ainda mais contemporânea, partindo da multidão e das redes de Negri para aproximar-se do que mais adiante será aprofundado neste trabalho, Manoel Castells destaca que "movimentos sociais em rede" acontecem em um "espaço da autonomia", consistente na interação de uma ocupação de espaços urbanos, como praças públicas e marchas nas ruas, com

\footnotetext{
${ }^{83}$ HARDT \& NEGRI, 2004, p. 140.

${ }^{84}$ Ibid., p. 436.

${ }^{85}$ Ibid., p. 146

86 "Em todas as atuais formas de produção social tendem a ter como central a produção do comum, que é a característica básica das formas predominantes do trabalho. Noutras palavras, o trabalho hoje cria formas comunicação e cooperação em rede, seja na produção de sementes geneticamente modificadas na agroindústria, seja na criação de softwares, pois o trabalho depende do conhecimento comum. Tal característica de produção comum é aplicável a todas as formas de trabalho, notadamente aquelas voltadas à criação de projetos imateriais como imagens, afetos e relações, modelo dominante nomeado por Negri como "produção biopolítica", visando enfatizar que não envolve apenas a produção de bens materiais em sentido estritamente econômico, mas também afeta e produz todas as facetas da vida social - econômicas, culturais ou políticas". Ver mais em: SILVA, 2014, p. 19-20.

${ }^{87}$ HARDT \& NEGRI, op. cit., p. 191.
} 
as redes de comunicação como a internet. A autonomia só pode ser garantida através da capacidade de organização nos espaços livres das redes de comunicação. Ao mesmo tempo em que pode ser "exercida como força transformadora, desafiando a ordem institucional disciplinar, ao reclamar o espaço da cidade para seus cidadãos. Autonomia sem desafio torna-se retirada." ${ }^{88}$. Para o referido autor, é necessária uma base permanente e autônoma para que o ativismo não seja interrompido.

O "espaço da autonomia" é o palco onde os movimentos acontecem. É nele que ocorre, através da deliberação, "a passagem da indignação à esperança" $^{\text {} 89}$. É, portanto, aqui considerada a mais importante característica dos movimentos dentre as apontadas pelo autor, pois o presente trabalho pretende olhar para este "terceiro espaço" como aquele ideal para o exercício do direito de resistência pelo poder constituinte.

A ausência de liderança e a absoluta vontade de assim se manterem está relacionada à própria existência dos movimentos, que repudiam justamente a política instituída, que os manipula e que os fazem não se sentirem representados. Daí o motivo pelo qual rejeitam qualquer forma de representação que torne o indivíduo capaz de tomar decisões importantes. "Trata-se, a um só tempo, de um procedimento organizacional e de um objetivo político: estabelecer os alicerces de uma futura democracia de verdade praticando-a no movimento" 90 .

$\mathrm{O}$ ato da comunicação ${ }^{91}$ é o que forma essas redes e, com o avanço da tecnologia, ampliou o seu alcance. A partir daí, emergiu o que Castells chamou de autocomunicação ${ }^{92}$, “com o potencial de alcançar uma

\footnotetext{
${ }^{88}$ CASTELLS, 2013, p. 161.

${ }^{89}$ Ibid., p. 162.

90 "São movimentos profundamente autorreflexivos porque, tanto o movimento quanto seus participantes questionam-se frequentemente a respeito de sua própria existência, de modo que constantemente reveem as suas ações e objetivos, na tentativa de manter-lhes no caminho que desejam seguir, evitando imprevistos e armadilhas conhecidas através da experiência de movimentos já derrotados". Ibid., p. 163.

91 "Comunicação é o processo de compartilhar significado pela troca de informações. Para a sociedade em geral, a principal fonte da produção social de significado é o processo da comunicação socializada. Esta existe no domínio público, para além da comunicação interpessoal." Ibid., p. 11.

${ }_{92} \mathrm{O}$ autor explana que: "É autocomunicação porque a produção da mensagem é decidida de modo autônomo pelo remetente, a designação do receptor é autodirecionada e a recuperação de mensagens das redes de comunicação é auto-selecionada. A comunicação de massa baseia-se em redes horizontais de comunicação interativa que, geralmente, são difíceis de controlar por parte de governos ou empresas." Ibid., p. 11.
} 
multiplicidade de receptores e de se conectar a um número infindável de redes que transmitem informações pelas vizinhanças ou pelo mundo" "93. Castells explica que:

A autocomunicação de massa fornece a plataforma tecnológica para a construção da autonomia do ator social, seja ele individual ou coletivo, em relação às instituições da sociedade. É por isso que os governos têm medo da internet, e é por isso que as grandes empresas têm com ela uma relação de amor e ódio, e tentam obter lucros com ela, ao mesmo tempo que limitam seu potencial de liberdade. (...) As redes de poder o exercem sobretudo influenciando a mente humana (mas não apenas) mediante as redes multimídia de comunicação de massa. Assim, as redes de comunicação são fontes decisivas de construção do poder. ${ }^{94}$

As ações coletivas perpetradas fora dos canais institucionais prescritos para tanto decorrem, muitas vezes, das condições degradantes às quais a coletividade é submetida pelo poder constituído. Também decorrem da falta de representatividade dos governantes - que, em regra, atuam em prol dos grupos econômicos e não das melhorias sociais - e da desconfiança das pessoas a respeito da possibilidade de haver mudanças no cenário degradante e desigual em que vivem.

Mas, os movimentos sociais não necessariamente emergem sempre destas situações, destacando Castells que as suas mobilizações podem também ser provocadas pelo sentimento de indignação que a injustiça promove, bem como o de esperança que contagia os indivíduos quando tomam conhecimento de que, em algum outro lugar (vizinho ou do mundo), a coletividade obteve êxito em suas reivindicações ${ }^{95}$.

O padrão comum existente na constituição dos movimentos sociais do século XXI identificado por Castells é o da utilização da internet. Destaca o autor que, não obstante possuam características próprias de cada país e local onde ocorreram, os movimentos em rede que surgiram a partir de 2011 e que contagiaram a juventude de muitos países, inclusive a brasileira, possuem características comuns: são conectadas em rede de múltiplas formas, sendo essencial o uso da internet e de telefones celulares, mas não só. Identifica que a conexão em rede se dá de forma "multimodal", existindo redes sociais on-

\footnotetext{
${ }^{93}$ CASTELLS, 2013, p. 12.

94 Ibid.

${ }^{95}$ Ibid., p. 158-159.
} 
line e off-line. Estas, por exemplo, como as redes preexistentes, mas, sobretudo, as formadas com o dinamismo de ações, referindo-se às redes formadas durante o movimento ${ }^{96}$.

Os movimentos podem também ser limitados pelo espaço urbano (ocupações e manifestações), mas não serão nas redes, pois na internet o espaço é livre e consiste em um espaço de autonomia. Esse espaço autônomo é "a nova forma espacial dos movimentos sociais em rede""97, o que lhes possibilita não ter lideranças, mas deliberações; não ter centros, mas diversos núcleos. Trata-se de movimentos com uma estrutura descentralizada, constituída de redes abertas.

As praças públicas e marchas nas ruas, aliadas às redes de comunicação, formam esse "espaço da autonomia", onde ocorrem os "movimentos sociais em rede", consistentes na interação com a ocupação daqueles espaços urbanos. E, para que esse "espaço da autonomia" não implique em retirada dos cidadãos das praças e das ruas, é necessário que a autonomia - organizada nos espaços livres das redes de comunicação - seja exercida como força transformadora, desafiando a ordem institucional disciplinar, reclamando aqueles espaços para os seus cidadãos ${ }^{98}$.

A solidariedade é, ao mesmo tempo, desenvolvida e estimulada pela horizontalidade, formando um círculo virtuoso em relação à desnecessidade de liderança, facilitando suas constantes autorreflexões enquanto movimento e enquanto indivíduo participante ${ }^{99}$.

A interação entre as comunidades locais e virtuais forma uma nova utopia, chamada por Castells de "utopia da autonomia do sujeito em relação às instituições da sociedade", uma vez que a mudança só pode ocorrer fora do sistema, mediante a transformação das relações de poder, sendo a internet uma plataforma fundamental (porém não fonte de causação social) porque promove

\footnotetext{
${ }^{96}$ CASTELLS, 2013, p. 160.

${ }^{97}$ Ibid.

${ }^{98}$ Ibid., p. 161.

99 "Sair do Facebook" e ir às ruas gritar "vem, vem, vem pra rua vem, a rua é nossa!" não significou para eles a abdicação dos meios para acessar, produzir e transmitir virtualmente informações e reflexões: as redes se tornaram formas essenciais de mobilização, propagação e denúncia, e uma nova figura de trabalhador e produtor cognitivo se afirmou ali: o "midiativista". A era da comunicação em tempo real, pelas mídias convencionais e pela internet, propiciara já, a essa multidão jovem, toda uma gama de referências relativas à natureza, à forma e à simbologia das rebeliões e dos tumultos metropolitanos por direitos acontecidos no exterior, nos quais as redes e as transmissões ao vivo pela internet se revelaram essenciais." PILATTI, 2016b, p. 8.
} 
a comunicação em grande escala. "As pessoas só podem desafiar a dominação conectando-se entre si, compartilhando sua indignação, sentindo o companheirismo e construindo projetos alternativos para si próprias e para a sociedade como um todo." 100 .

Uma vez explicada a forma de interação dos movimentos conforme a visão de Castells e após compreendermos a dimensão tumultuária do poder constituinte de Negri, pode-se afirmar, então, que a multidão que foi às ruas participar dos movimentos iniciados em 2013 é a aquela que preenche de multiplicidade o "espaço de autonomia". Reuniram-se, sem pretensão de formar uma unidade, contra as instituições estatais que garantem apenas igualdade e liberdade formais, porém, na prática, violentam, discriminam e reprimem a maior parcela da sociedade, sobretudo no tocante à sua participação efetiva na democracia ${ }^{101}$.

\section{2}

\section{Direito penal do inimigo: controle e repressão - a política criminal do poder constituído}

A sociedade pós-moderna é uma sociedade de controle como pensou Deleuze, afirmando seguir o pensamento de Foucault relativo à sociedade moderna disciplinar ${ }^{102}$. Foucault, a partir da análise das relações de poder,

\footnotetext{
${ }^{100}$ CASTELLS, 2013, p. 166.

101 “(...) junho não se fez "apenas" com manifestações que se tornaram gigantescas: fez-se também com assembleias populares abertas, com ocupações de espaços públicos, intervenções-surpresa em eventos oficiais ou para oficiais, além de uma súbita multiplicação de reuniões e debates realizados em casas particulares, praças, instituições de ensino e de classe, por meio dos quais se tentava compreender o sentido que as manifestações e seus desdobramentos iam produzindo." PILATTI, 2016b, p. 10.

${ }^{102}$ Para Hardt, "a formulação dessa ideia por Deleuze, no entanto, é bastante exígua (...). Ele nos diz muito poucas coisas concretas sobre a sociedade de controle. Ele constata que as instituições que constituíam a sociedade disciplinar - escola, família, hospital, prisão, fábrica, etc. - estão, todas elas e em todos os lugares, em crise. Os muros das instituições estão desmoronando de tal maneira que suas lógicas disciplinares não se tornam ineficazes, mas se encontram, antes, generalizadas como formas fluidas através de todo o campo social. O 'espaço estriado' das instituições da sociedade disciplinar dá lugar ao 'espaço liso' da sociedade de controle. Ou, para retomar a bela imagem de Deleuze, os túneis estruturais da toupeira estão sendo substituídos pelas ondulações infinitas da serpente. Enquanto a sociedade disciplinar forjava moldagens fixas, distintas, a sociedade de controle funciona por redes flexíveis moduláveis, "como uma moldagem autodeformante que mudasse continuamente, a cada instante, ou como uma peneira cujas malhas mudassem de um ponto a outro" (Deleuze, Pos-Scriptum sobre as sociedades de controle)." HARDT, 2000, p. 1.
} 
compreendeu "que o poder é um conjunto de mecanismos e de procedimentos que têm como papel ou função e tema manter justamente o poder", e iniciou uma análise global da sociedade que, para ele, tem o papel de mostrar quais os "efeitos de saber que são produzidos em nossa sociedade pelas lutas, os choques, os combates que nela se desenrolam, e pelas táticas de poder que são os elementos dessa luta" $" 103$.

Foucault identifica métodos de passagem para o exterior das instituições da sociedade disciplinar (exército, hospitais, escolas, prisões, etc.). Primeiro, analisou que a passagem se dá pela substituição "do ponto de vista global da tecnologia de poder", consistente em uma análise que "reconstitui toda uma rede de alianças, de comunicações, de pontos de apoio". Segundo, a promoção da troca de ponto de vista interno das instituições, antes baseadas na sua função, por um ponto de vista externo das estratégias e táticas, que muitas vezes se apoiam no argumento da funcionalidade. O terceiro método consiste em ressituar o objeto sem a admissão de sua entrega "pronta", não permitindo "medir as instituições, as práticas e os saberes com o metro e a norma desse objeto já dado" ${ }^{104}$.

Michael Hardt repensa a contemporaneidade como uma sociedade global de controle, através do desenvolvimento das características que marcam a passagem da sociedade disciplinar da modernidade para a sociedade pós-moderna, já que não identifica em Deleuze uma demonstração de como se dá essa passagem ${ }^{105}$. Hardt, em conjunto com Negri, elaborou dois processos que balizam essa transição: o enfraquecimento da sociedade civil que "remete ao declínio das funções mediadoras das instituições sociais" e a passagem do imperialismo ao império, “à nova ordem mundial, que se entende hoje em torno dos Estados Unidos, com as instituições transnacionais e o mercado mundial" 106 .

\footnotetext{
${ }^{103}$ FOUCAULT, 2008, p.4-5.

${ }^{104}$ Ibid., p. 157-158.

105 “O que Deleuze nos propõe é, de fato, uma simples imagem dessa passagem, uma imagem sem dúvida bela e poética, mas não suficientemente articulada para nos permitir compreender essa nova forma de sociedade. Para fazer isso, pretendo relacioná-la a uma série de outras passagens que foram propostas para caracterizar a sociedade contemporânea. Pretendo, portanto, tentar desenvolver a natureza dessa passagem, estabelecendo sua relação com a passagem da sociedade moderna à sociedade pós-moderna". Ibid.

${ }^{106}$ Ibid.
} 
A transição de uma sociedade disciplinar (moderna) para a sociedade mundial de controle (pós-moderna, que chamou-se de império) é marcada pela derrubada dos muros de definições das instituições, de modo que há mudança na perspectiva sob o que é de fora, uma vez que já não há barreiras separandoo de dentro. Enquanto na sociedade moderna as barreiras de diferenciação encontravam-se nas fronteiras territoriais, étnicas e culturais estabelecidas entre as nações e povos, na sociedade imperial, do mundo globalizado, tais fronteiras são inexistentes, o que faz com que as diferenciações se deem numa perspectiva interna e não mais externa à fronteira.

"A dialética moderna do fora e do dentro foi substituída por um jogo de graus e intensidades, de hibridismo e artificialidade" ${ }^{\text {107 }}$, de modo que tal dialética, também presente na modernidade entre o espaço público (fora) e o privado (dentro), deu lugar a espaços públicos cada vez mais privatizados, sem possibilidade de compreensão da organização social à luz desta distinção ${ }^{108}$. Hardt sintetiza tal ideia desta forma:

Na sociedade pós-moderna, o espetáculo é um lugar virtual ou, mais exatamente, um não-lugar da política. O espetáculo é simultaneamente, unificado e difuso, de tal modo que é impossível distinguir um dentro de um fora - o natural do social, o privado do público. A noção liberal do público como o lugar de fora, onde agimos sob o olhar dos outros, tornou-se ao mesmo tempo universalizada (pois somos hoje permanentemente colocados sob o olhar dos outros, sob a observação das câmeras de vigilância) e sublimada, ou desrealizada, nos espaços virtuais do espetáculo. O fim do fora é, assim, o fim da política liberal ${ }^{109}$

Para além da organização social e da política, Hardt demonstra ainda que há um terceiro lugar onde já não existe mais o fora: trata-se do sentido militar da sociedade global de controle, sendo este o aspecto mais relevante para o presente trabalho. Neste ponto, o autor explica que a potência soberana pretenderá abranger o seu domínio, progressivamente, de maneira global, deixando de se preocupar com um confronto com outro Estado, pois não o afrontará e tampouco será afrontado. A pós-modernidade é caracterizada por conflitos menores e interiores ou, como Hardt bem disse, "cada guerra imperial é uma guerra civil, uma ação da polícia" ${ }^{\prime 10}$.

\footnotetext{
${ }^{107}$ HARDT, 2000, p. 2

${ }^{108}$ Ibid.

109 Ibid.

${ }^{110}$ Ibid.
} 
Deixa, então, de existir o fora que dava coerência à guerra imperialista da modernidade e passam a surgir crises menores e mal definidas na sociedade imperial de controle: "parece que há, em todos os lugares, inimigos menores e imperceptíveis" "111. É neste cenário que Hardt destaca que a transição para a sociedade mundial de controle também atingiu o racismo e a produção social da subjetividade. Em síntese, o racismo imperial se distancia da dialética povo de dentro versus povo de fora (outros), para integrar os outros em sua ordem, gerindo as microconflitualidades dentro de seu sistema de controle ${ }^{112}$.

Quanto à produção da subjetividade na sociedade mundial de controle, o autor destaca que o colapso das instituições da sociedade moderna faz com que tal produção na sociedade imperial não se limite a lugares específicos como antes (escola, fábrica, prisão, igreja), de modo que, na pósmodernidade, as instituições sociais "poderiam ser percebidas em um processo fluido de engendramento e de corrupção da subjetividade"113. Com isso, destaca o autor que deveria se reconhecer que neste aspecto há operação por parte dos aparelhos ideológicos do Estado ${ }^{114}$.

As contradições, na sociedade imperial, são múltiplas, e proliferam em todos os lugares. Os espaços dessa sociedade são impuros, híbridos. O conceito que a caracteriza, portanto, não é o de crise, mas o de oni-crie ou, ou como prefiro dizer, de corrupção. ${ }^{115}$

A sociedade mundial de controle é, portanto, segundo Hardt, uma sociedade que se esfacela, se corrompe e se deforma, junto com suas instituições. Nesta sociedade, o poder marca o espaço e tem como objetivo a natureza humana. As microconflitualidades identificadas pelo autor como características da sociedade contemporânea como, por exemplo, as ações policiais, as guerras civis, etc., obedecem, segundo o que Hardt propõe, a uma estratégia do Estado para manutenção da ordem e dos interesses do capital.

Neste contexto, parece-nos oportuna a teoria defensora da lógica de que os inimigos da sociedade devem receber tratamento jurídico diferenciado.

\footnotetext{
${ }^{111}$ HARDT, 2000, p. 3.

112 Ibid., p. 5.

${ }^{113}$ Hardt explica que o sentido de corrupção aqui se refere a um processo inverso ao da geração, "como um devir dos corpos, um momento no vaivém da formação e da deformação das subjetividades". Ibid., p. 8.

114 Ibid., p. 7.

115 Ibid.
} 
A teoria jurídico-penal que discursa a respeito da prevenção geral positiva do Direito Penal foi reutilizada por Gunther Jakobs ${ }^{116}$ e acredita que a luta contra a criminalidade se dá através da pena criminal. O penalista recupera tanto princípios do direito penal liberal clássico quanto do positivismo do século XIX, para dividir o Direito Penal em dois sistemas: a pena para o cidadão e a pena para o "perigoso", tratado como inimigo. Enquanto para o cidadão "a pena criminal preservaria o significado simbólico de (re)afirmação da validade das normas, como sanção contra fatos passados" ${ }^{\text {117 }}$, para o inimigo, a pena criminal tem característica preventiva, para evitar fatos futuros ${ }^{118}$. Estes são, em tese, os que cometem crimes que assumem atitude de insubordinação jurídica com capacidade de produzir em estado de guerra contra a sociedade, "perdendo a qualidade de pessoa portadora de direitos, porque desafia o sistema social"119.

A referida teoria fundamenta-se em uma dicotomia entre "anjos e demônios, ou entre bons e maus, ou entre nós e eles", considerando cidadão o indivíduo que tem fidelidade jurídica correspondente às expectativas da ordem social, atrelada a um "modus vivendi comum", enquanto o inimigo tem “intrínseca incapacidade de orientação normativa", não correspondendo às expectativas da comunidade, porquanto incapaz de viver comumente: "seria uma personalidade criminógena definível como adversário de princípio da organização do poder social" ${ }^{120}$.

Segundo Jakobs, o direito penal do inimigo é para os integrantes de organizações criminosas ou outros criminosos "por tendência", como os que

\footnotetext{
${ }^{116}$ Professor Doutor da Universidade de Bonn, Alemanha, Jakobs faz uma releitura da denominada 'prevenção geral positiva', através de Hegel e partindo da concepção do direito de Luhnmann. Ver mais em ZAFFARONI, 2007.

${ }^{117}$ SANTOS, 2012, p. 5.

${ }^{118}$ Para Jakobs, "la existencia de un Derecho penal de enemigos no indica la fortaleza del Estado de libertades, sino, por el contrario, un signo de que en esa medida simplemente no existe. Ciertamente son posibles situaciones, que quizás se dan incluso en este momento, en las que las normas imprescindibles para un Estado de libertades pierden su poder de vigencia si se aguarda con la represión hasta que el autor salga de su esfera privada. Pero incluso entonces el Derecho penal de enemigos sólo se puede legitimar como un Derecho penal de emergencia que rige excepcionalmente. Los preceptos penales a él correspondientes tienen por ello que ser separados estrictamente del Derecho penal de ciudadanos, preferiblemente también en su presentación externa... el Derecho Penal de enemigos tiene que ser también separado del Derecho penal de ciudadanos de un modo tan claro que no exista peligro alguno de que se pueda infiltrar por medio de una interpretación sistemática o por analogía o de cualquier otra forma en el Derecho penal de ciudadanos.". JAKOBS, 1997, p. 322-323.

${ }^{119}$ SANTOS, op. cit., p. 5.

${ }^{120}$ Ibid., p. 6.
} 
praticam crimes econômicos e sexuais, mas especialmente o terrorista, que é "aquele que nega, em princípio, a legitimidade da ordem jurídica, e por isto se propõe a destruir esta ordem jurídica". Não se tem garantia da conduta criminosa da pessoa "perigosa". Com base em suas premissas ideológicas provavelmente decorrentes de suas opções pessoais que "cancelam princípios jurídicos civilizados separando a população entre cidadão e inimigos"121 Jakobs teorizou que os crimes desta natureza devem ser processados sem garantias processuais.

Com isso, a proposta do direito penal do inimigo introduz no sistema de justiça criminal um duplo sistema de imputação penal e processual penal, no qual o cidadão é punido por fato passado, através do direito penal da culpabilidade baseado no sistema acusatório; e ao inimigo cabe um direito penal preventivo, fundado no sistema inquisitório ${ }^{122}$, e no qual não existem as garantias do devido processo legal. Em seu lugar, há presunção de culpa, restrição à ampla defesa, medidas arbitrárias como proibição de contato com advogado, etc.. A supressão de garantias constitucionais é expressamente proposta na teoria do direito penal do inimigo na medida em que Jakobs defende que o processo penal do inimigo não pode ser designado em conformidade com a Justiça porque deve ter forma de guerra ${ }^{123}$.

A teoria de Jakobs ignora, então, que as teorias políticas da criminalização evidenciam uma seletividade para a definição de crimes e produção de criminosos que está presente nas sociedades estabelecidas na contradição entre trabalho assalariado e capital. Ao contrário, a teoria deste autor alemão tem fundamento na teoria da criminalização como controle social que, em verdade, promove uma lógica perversa, bem explicada nas palavras de Juarez Cirino dos Santos: "a violência autoritária das elites de poder econômico e político das sociedades contemporâneas costuma existir sob a forma de primários programas repressivos de controle da criminalidade" $" 124$.

\footnotetext{
${ }^{121}$ SANTOS, 2012, p. 10.

122 A respeito dos sistemas acusatório e inquisitório, ver em: PRADO, Geraldo. Sistema acusatório: a conformidade constitucional das leis processuais penais. $4^{\mathrm{a}}$ ed. Rio de Janeiro: Lumen Juris, 2006.

${ }^{123}$ SANTOS, op. cit., p. 11.

${ }^{124}$ Ibid., p. 15.
} 
É nesse contexto que as ideias trazidas pela teoria do direito penal do inimigo não só fazem parte do conhecido discurso que esconde a real função da pena e do processo penal nas sociedades modernas, que é a garantia da desigualdade social, como também aprimoram o discurso conservador, uma vez que a pena e o processo penal desiguais para o inimigo não só garantem a desigualdade social, como a ampliam ${ }^{125}$.

Em conclusão, se o princípio de igualdade perante a lei é substituído pelo princípio da desigualdade legal, ou se as garantias constitucionais do processo legal devido são casuísmos dependentes do tipo de autor - aplicadas ao cidadão e negadas ao inimigo, conforme preferências idiossincráticas dos agentes de controle social -, então o Estado Democrático de Direito está sendo deslocado pelo estado policial. ${ }^{126}$

Concordamos com a conclusão de Juarez Cirino dos Santos em relação ao estado policial ${ }^{127}$ implementado pela teoria do direito penal do inimigo, mais ainda com a menção a sua aplicação conforme as escolhas dos agentes de controle social, como, na verdade, uma verdadeira estratégia do Estado para manutenção da ordem e dos interesses do capital. Tais escolhas e estratégias são denominadas pela criminologia como políticas criminais.

A política criminal, segundo Nilo Batista, é constituída pelos institutos normativos e não normativos, pelas diretrizes políticas de instituições, os agentes e atores que estão ligados ao sistema penal de determinado Estado por orientação do poder constituído ${ }^{128}$. Neste contexto, a repressão à multidão constituinte aqui abordada está alinhada com uma política criminal direcionada à determinada parcela da sociedade, com vistas a mantê-la distante, acuada e controlada para a manutenção do poder constituído, posto que este considera a multidão como o inimigo que deve ser combatido através de restrições de suas garantias constitucionais.

\footnotetext{
${ }^{125}$ SANTOS, 2012, p. 18.

${ }^{126}$ Ibid., p. 20.

127 "O estado de direito é um produto da modernidade, que se estendeu por uma parte limitada do planeta, mas que não fez desaparecer o poder exercido conforme o modelo do estado de polícia. A luta entre o modelo de estado de direito e estado de polícia continua em todo o mundo, mas não somente frente aos autoritarismos instalados, mas sim também dentro das democracias. O estado de direito ideal é justamente ideal, ou seja, que não há estados de direito perfeitos na realidade, mas sim que todos os estados reais de direito (por óbvio que também os estados latino-americanos) são de direito até certo grau de perfeição.” In: ZAFFARONI, SLOKAR \& ALAGIA, 2005, p. 21.

${ }^{128}$ BATISTA, 2001, p. 34.
} 
A essa parcela da sociedade são negados os direitos da cidadania (tais como saúde, transporte público, educação e lazer), distanciando-os dos interesses do capital e aproximando-os do conceito de inimigo. Isto ocorre especialmente quando esta resolve rebelar-se contra o status quo, promotor e estabilizador da desigualdade, que aumenta com o incremento da repressão do Estado aos que pretendem mudar sua realidade, formando uma espécie de ciclo vicioso que, propositalmente, é alimentado pelo Estado ${ }^{129}$.

Ao discorrer sobre o inimigo do século XXI, Zaffaroni revela que houve produção legislativa com viés autoritário com o fim de combater o crime organizado - conceito equivalente à "criminalidade de mercado" - que Zaffaroni explica estar complementado pela corrupção pública. Juntos (crime organizado e corrupção pública) habilitam o poder punitivo e a intromissão do Estado "sem os limites nem as garantias constitucionais para tais intervenções" $" 130$.

O autor explica que o autoritarismo norte-americano é o mais difundido do mundo e, especialmente na América Latina, "dada a sua precariedade institucional", a exclusão social e a deterioração da classe média, ele funciona como um mecanismo de aprofundamento das contradições internas. Mas, ao contrário do funcionalismo do discurso autoritário implementado nos Estados Unidos (qual seja, resolver o problema do desemprego), aqui na América Latina o poder repressivo "serve para controlar os excluídos de empregos, torna-se brutalmente violento, e as polícias autonomizadas e em dissolução dão lugar aos poderes políticos"131.

Zaffaroni explica também que o êxito publicitário verificado com a promoção da vingança reforça o preconceito de que a repressão, através da disciplina, põe ordem em um mundo desordenado. Nesse sentido, “a sucessão de inimigos aumenta a angústia e reclama novos inimigos para acalmá-la,

\footnotetext{
${ }^{129}$ TOLEDO, 2014, p. 40.

${ }^{130}$ ZAFFARONI, 2010, p. 28-29. A título exemplifictaivo, Zaffaroni destaca a seletividade do poder repressivo norte americano em prol do interesse do capital, na medida em que "no marco de uma economia de serviços, o sistema penal converteu-se num fator de redução do índice de desemprego."Ibid., p. 27.

Sobre o viés autoritário, discorre que "impulsionou-se uma legislação inquisitória, com elementos provenientes da Idade Média (espiões, delatores, procedimentos secretos etc.) aplicáveis a um nebuloso conjunto de infrações designadas como crime organizado, que motivou um número incrível de instrumentos internacionais." Ibid., p. 28.

${ }^{131}$ Ibid., p. 31-32.
} 
pois, sem conseguir um bode expiatório, a potência passa a ter forma circular". O inimigo reconhecido pelo o que Zaffaroni chama de "discurso autoritário cool" é sempre aquele que o confronta: "um discurso que está proibido contradizer, inclusive o próprio Estado, porque o único inimigo fixo

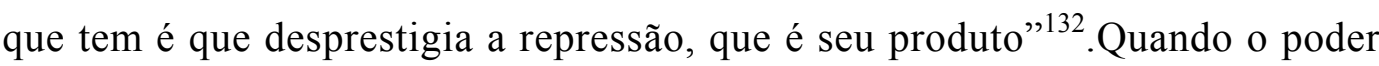
soberano não é capaz de manter a relação de soberania por meios pacíficos, utiliza-se da violência, o que expõe o projeto da multidão à uma concepção nova de guerra, que força a multidão a se defender, impondo no projeto da democracia absoluta a necessidade da resistência ${ }^{133}$.

Tais afirmações retornam à reflexão acerca do que Negri e Hardt, em sua obra Império, explicam a respeito de controle e repressão na atualidade. Os autores expõem a mudança nas perspectivas das guerras que, se antes eram entre Estados soberanos para estabelecer o poder diante de outras nações; hoje são "guerras" como as guerras civis e as "intervenções" que, em regra, estão dentro do próprio Estado mas acontecem, na verdade, objetivando a construção - e, depois, a reiteração de sua existência - de um inimigo que justifique uma desproporcional repressão, para então alcançar o objetivo final: a manutenção do status quo através da sua criação e do estímulo ao seu combate. Ao que nos parece, assim foi feito em 2013, com a instrumentalização de meios legais repressivos direcionados aos levantes das ruas.

O extermínio do inimigo não interessa ao poder constituído: interessalhe estimular a sua existência para dar continuidade a ele próprio. Em outras palavras, a "guerra" passa a ser um mecanismo de manutenção de poder, e não de sua disputa. Tal mecanismo é alimentado através da criação do inimigo, de uma figura a ser permanentemente combatida pelo Estado que, na verdade, tem a pretensão de alimentar a existência de um inimigo. Com isso, o poder constituído, mesmo através de meios que não se adequam às garantias

\footnotetext{
132 ZAFFARONI, 2010, p. 33 e 35.

${ }^{133}$ Fabrício Toledo explica que, no novo paradigma global de Negri e Hardt, "a guerra não é uma ameaça à estrutura de poder, mas, ao contrário, um mecanismo ativo que constantemente reforça a atual ordem global. O específico de nossa época é que a guerra deixou de ser o elemento final das sequencias de poder - a força letal como último recurso - para se tornar o primeiro e fundamental elemento, constituindo a base da própria política. A aplicação constante e coordenada da violência é a condição indispensável para o funcionamento da disciplina e do controle." TOLEDO, 2014, p. 40 .
} 
fundamentais dos indivíduos, mantém, a qualquer custo, o caminho aberto para a contínua expropriação dos bens comuns ${ }^{134}$.

O modelo de guerra mencionado, além de fomentar o combate a um inimigo, também atende às convencionais intenções do poder soberano, que é a repressão a qualquer movimento de resistência e a imposição da ordem à multidão. A repressão criminal, nesta conjuntura, constitui um instrumento utilizado pelo poder constituído para garantir a sua própria estabilidade, proteger os interesses do mercado e esmagar os desejos da multidão. Além da violência cometida nas ruas, o poder estatal utiliza-se de novos e velhos institutos processuais penais com vistas a se legitimar pelo direito.

No contexto do presente trabalho, que enfrenta a repressão do poder constituinte dos levantes de 2013, trazer a discussão a respeito do direito penal do inimigo é relevante porque à multidão que resiste e questiona, que promove um levante e se organiza em redes, foi dado o tratamento como inimigo, como sujeito que precisa ser rapidamente combatido para que haja a manutenção do status quo. A respeito do tema, destaca-se a pesquisa do professor Geraldo Prado, indicando que:

Salta aos olhos que o processo deflagrado no âmbito das instancias jurídicopenais, com apelo às agências de controle social e adoção de repressão penal como método central de reação às manifestações evidenciou o quanto as autoridades públicas encontram-se despreparadas para entender e lidar com demandas que não se enquadram mais no esquema conceitual das classes e seus conflitos. ${ }^{135}$

Giuseppe Cocco e Adriano Pilatti, no auge dos levantes de 2013, partiram da concepção de Negri a respeito da capacidade da multidão de promover o novo, e afirmaram que o caminho seria promover "a tradução política da potência do levante, o que seria uma inovação radicalmente democrática" $" 136$.

Contrapondo a expectativa vivida em 2013, no sentido de que era possível abrir o procedimento constituinte àqueles que lhe integram -

\footnotetext{
${ }^{134}$ Ibid.

${ }^{135}$ PRADO et. al., 2015, p. 254 (grifos meus).

136 "Ao contrário, se [abrissem] corajosamente aos momentos constituintes que se multiplicam, retomando e ampliando a política dos pontos de cultura, contrapondo-se às políticas de remoções dos pobres, repensando os megaeventos, discutindo a democratização da comunicação, propondo a desmilitarização da segurança pública, a tradução política da potência do levante será uma inovação radicalmente democrática." COCCO \& PILATTI, 2013.
} 
formadores da multidão -, aos reais instrumentos de repressão utilizados no Rio de Janeiro, percebe-se que meios efetivos para o direito de resistência devem ser pensados à luz da concepção materialista do poder constituinte, de modo a impedir que a soberania do Estado continue - como continua recorrendo a mecanismos de repressão autoritários, porém formalmente instituídos com vistas a manter o status quo.

No próximo capitulo serão enfrentadas algumas diretrizes de política criminal, extraídas de pesquisa realizada sobre determinados atos relacionados com a repressão criminal das manifestações ocorridas no Rio de Janeiro, a partir de junho de 2013. 


\section{3: O Levante e a Repressão no Estado do Rio de Janeiro}

A multidão ${ }^{137}$ que tomou as ruas do Rio de Janeiro representou uma convergência de desejos de uma juventude conectada e contagiada não só pelos tumultos iniciados em Porto Alegre e em São Paulo, mas também com os levantes em diversos países, iniciados a partir de $2010^{138}$. A multidão heterogênea e unida, e cada sujeito, singular à sua maneira, ansiavam por melhorias no transporte público; por acesso a serviços essenciais, à cultura e ao lazer; pela tão distante dignidade da vida nas favelas, onde diariamente há execução sumária de pretos e pobres.

\footnotetext{
137 "Dizer que as revoltas surgidas nas ruas de Rio e São Paulo, em 2013, foram organizadas na forma de multidão significa dizer que - em vez de dirigidas pelo partido ou uma direção ou mesmo um comitê de lideranças acimadas massas - os movimentos foram auto-organizados, conectados horizontalmente pelo território social. Os movimentos não foram (e não se esforçam por ser) unificados e homogêneos, mas sim encontraram meios adequados para exprimir suas diferenças e antagonismos internos - e apesar de (ou por causa de) suas diferenças, descobriram maneiras de troca comum e cooperação, gerando uma série de demandas e perspectivas agrupadas na luta. Tal multidão não é desorganizada e não se forma espontaneamente, ao invés disso ela requer uma atividade constante e intensa de organização." HARDT, 2014, p. 7-10.

138 “(...) Tiveram como antecedente a uma tumultuária 'giornata' romana de 14 de dezembro de 2010: Primavera Árabe, 15M, Occupy Wall Street. Roma, Madri, Barcelona, Lisboa, Atenas, Túnis, Trípoli, Cairo, Istambul, Nova Iorque: em três continentes, as ruas foram tomadas por uma humanidade jovem, escolarizada, conectada à rede mundial de computadores e às redes sociais que nela se multiplicavam velozmente, espelhando uma nova configuração do trabalho caracterizada pela produção imaterial e pela precarização. Nesses levantes, a resistência se voltava contra as novas formas, mundialmente difundidas, de exploração do trabalho e de apropriação privada de bens e espaços públicos, e também contra as instituições políticas que as facilitavam. As estratégias de mobilização adotadas pelos insurgentes se caracterizavam por uma incessante interação retroalimentadora entre as redes sociais virtuais e as ruas e praças. (...) $\mathrm{O}$ impacto desses movimentos foi também global e encontrou eco no Brasil: um exemplo foi o Ocupa Rio, acontecido já em 2011 na emblemática Cinelândia carioca (palco de tantas manifestações históricas que seria, também em 2013, locus destacado dos acontecimentos), afirmou-se como ponto de encontro e discussão para onde convergiram centenas de ativistas e vários coletivos que estariam nas ruas dois anos depois, integrados ou conectados a novos coletivos que a partir dali começaram a se formar." PILATTI, 2016b, p. 4.
} 
A ação política direta e o dissenso democrático enérgico se reincorporaram à democracia brasileira. Uma nova geração de jovens cidadãs e cidadãos integrados em uma multiplicidade de grupos e movimentos (e muitos militantes autônomos) tem ensinado cotidianamente a toda a sociedade, à classe política, à esquerda crepuscular, às organizações patrocinadas e à "intelectualidade" que é possível organizar horizontalmente e assim constituir o comum na multiplicidade, por meio e não contra a autonomia das singularidades - sem hierarquia, precedências, capturas, cooptações, 'autoridades', 'mentores', preceptores, et caterva. ${ }^{139}$

Especialmente no Rio de Janeiro ${ }^{140}$, o levante de 2013 foi também contagiado pela mobilização de movimentos sociais que já denunciavam as políticas de remoção em massa para a Copa do Mundo - que teve como "prévia" a realização da Copa das Confederações em junho de 2013. Estes enfrentavam o discurso do poder constituído, que considerava aquele grande evento primordial para o Estado da Guanabara: “Copa para quem?”, "Não vai ter Copa”, entre tantas outras tentativas de desconstruir os interesses do capital com a usurpação dos direitos dos pobres.

A grande mídia, aparentemente perdida diante daquele gigante monstruoso que acordava, daquele devir-multidão, deu publicidade negativa aos movimentos e passou a ser incluída na pauta das ruas, foi rechaçada, confrontada e ainda mais desmoralizada. Tentou recuar, mas era tarde. Virou-se, então, novamente, contra os movimentos de forma ainda mais tendenciosa, distorcida e suspeita. Enquanto uns tentavam compreender o que acontecia nas ruas, outros somavam-se à multidão insurgente.

O Estado que admite a liberdade de manifestação (enquanto resistência) apenas enquanto os interesses do capital não estão em perigo fez-se progressivamente autoritário e soberano no Rio de Janeiro em junho de 2013, mostrando-se disposto a manter o status quo a qualquer custo, através de repressão policial desproporcional, promulgação de normas inconstitucionais,

\footnotetext{
${ }^{139}$ PILATTI, 2016b, p. 54.

140 “'(...) no Rio, o ambiente era de crescente descontentamento em relação ao governo estadual, em decorrência do recrudescimento da violência policial contra os pobres, dos grandes gastos e perceptível corrupção conexa resultantes de obras de prioridade questionável, da submissão das decisões públicas aos interesses dos carteis dos transportes da construção civil. Além disso, o governo fluminense estava seriamente desgastado pela postura autoritária de intransigência e repressão que adotara em relação a movimentos reivindicatórios como o dos bombeiros em 2011. Tudo aquilo, enfim, que depois viria a se concentrar no sintético e profundo "Fora Cabral", que ecoou durante meses nas ruas cariocas. Dia após dia e um pouco em toda parte, a sensação crescente era de descontentamento, um descontentamento difuso que marcava o início do esgotamento do consenso alimentado pelo crescimento econômico e pela redução das desigualdades que haviam caracterizado os anos anteriores." Ibid., p 5.
} 
prisões arbitrárias, flagrantes forjados, proibição de manifestações culturais ${ }^{141}$, proibição do uso de máscaras, agilidade na tramitação de leis com viés incriminatório, somadas tais medidas à estratégia midiática de desmoralização e deslegitimação dos movimentos nas ruas. Manifestantes foram incluídos à categoria de inimigos, juntando-se àqueles de longa data: jovens, pretos, pobres, favelados.

O presente trabalho destaca, então, três momentos que contribuíram para o enfraquecimento - através da repressão violenta e desproporcional - do movimento constituinte emerso das ruas em 2013, na cidade do Rio de Janeiro, marcando uma verdadeira instrumentalização da repressão à multidão: (i) no plano executivo estadual, a criação da CEIV - Comissão Especial de Investigação de Atos de Vandalismo, através de decreto; (ii) na esfera federal, a tramitação em regime de urgência e a sanção, pela Presidenta Dilma Rousseff, em 2 de agosto de 2013, da Lei $\mathrm{n}^{\circ}$ 12.850, que "define organização criminosa e dispõe sobre a investigação criminal, os meios de obtenção da prova, infrações penais correlatas e o procedimento criminal" ${ }^{142}$; e (iii) no âmbito da justiça estadual, o Inquérito Policial que culminou com as prisões efetuadas no âmbito do "processo dos $23^{\prime \prime 143 .}$

A título de exemplo das diversas ações, Eduardo Baker e Natália Damazio, analisaram os arquivos ${ }^{144}$ das principais delegacias do Rio de Janeiro responsáveis por lavrar os registros de ocorrência, os termos circunstanciados e os flagrantes referente às jornadas iniciadas em junho de 2013. Seu trabalho demonstra a

${ }^{141}$ Como os "rolezinhos", por exemplo.

142 BRASIL. Lei $\mathrm{n}^{\circ}$ 12.850, de 2 de agosto de 2013. Diário Oficial da República Federativa do Brasil, Brasília, DF, 3 ago. 2013. Disponível em: $<$ https://www.planalto.gov.br/ccivil_03/_ato2011-2014/2013/lei/112850.htm>. Acesso em: 12 set 2016.

${ }^{143}$ Admitimos, entretanto, existirem inúmeros outros fatos e outras diversas ações institucionalizadas de repressão, ambos próprios de um Estado policial e autoritário, tanto formais quanto informais, implementados pela política criminal do Estado e que também contextualizam a questão levantada, mas que, por limitações de recorte de pesquisa, não serão enfrentados neste trabalho.

${ }^{144}$ Referem-se a arquivo como "o local onde documentos são juntados, ordenados e protegidos, ao mesmo tempo em que disponibilizados (...) que na prática não implica uma garantia de acesso à informação nele contida. (...) Estes expedientes ocultam as razões do Estado, em seus atos de violência. Ocultam, na medida em que são produzidos e arquivados em gaveteiros, pelas diversas delegacias espalhadas pela cidade ou pelos discos rígidos de seus computadores. (...) Ocultam, também, o ato de violência que Derrida chama de 'violência de arquivo'. O ato de inscrever no documento aquilo selecionado para estar nele. A escrita e o arquivamento são seletivos. Omitem para contar uma história que não é a do oprimido. No caso do sistema penal, deixam de fora, - ou tentam deixar, - as marcas da violência do poder punitivo." BAKER \& DAMAZIO, 2014, p. 88. 
pretensão do Estado de desmontar a articulação da multidão através de uma violência institucional do poder punitivo constituído. Os autores lembram que a repressão ao levante foi marcada pelo resgate de determinados comportamentos semelhantes (para não dizer iguais) aos dispensados aos resistentes à Ditadura Militar, demonstrando que, para o Estado, existe um liame subjetivo entre aqueles e estes resistentes. Diferenciam, agora, o seu vocabulário: dantes "subversivos", agora praticantes de "terrorismo" e integrantes de "organização criminosa"

Exemplo simbólico é o caso do "morador de rua" Rafael Braga, que esteve preso preventivamente por 5 meses porque, na manifestação do dia 20 junho de 2013, foi supostamente flagrado levando consigo duas garrafas de produtos de limpeza, compostos pelo desinfetante Pinho Sol e um frasco de água sanitária. Por este fato nada criminoso, acabou condenado a 5 anos de prisão e, a cada progressão de regime que teve direito, foi perseguido por esse Estado policial até que acabou preso por associação ao tráfico e por tráfico de drogas, em flagrante aparentemente forjado, voltando à prisão por este motivo, após já ter alcançado o benefício do monitoramento eletrônico no processo do "flagrante" de $2013^{146}$.

\footnotetext{
145 BAKER \& DAMAZIO, 2014, p. 90-91.

146 "Rafael Braga Vieira passou a ser inimigo declarado do Estado. Negro, pobre e da periferia, o crime em questão foi ser a carne mais barata do mercado. Recentemente, Rafael surgiu do esquecimento que the foi imposto pelo Estado e pela esquerda institucional, a qual, em regra, deixou de debater seu caso. O triste ressurgimento de Rafael Braga foi traduzido na notícia de que ele foi condenado, em 20 de abril, a cumprir 11 anos e três meses de reclusão, acrescidos de pagamento de uma multa de aproximadamente $\mathrm{R} \$ 1.600,00$. (...) Rafael Braga, no entanto, que sequer participava do ato (...). Sob a alegação de que os produtos seriam usados na produção de coquetel molotov, a partir daquela data ficou preso durante 5 meses até o julgamento, quando então foi condenado a 5 anos de prisão, apesar de contar com o laudo favorável do Esquadrão Antibomba da Polícia Civil atestando o óbvio de que Pinho Sol e água sanitária não poderiam jamais ser considerados como explosivos. Em 2014, Rafael chegou a conseguir o benefício do trabalho externo e passou para o regime semiaberto podendo exercer a função de auxiliar de serviços gerais num escritório de advocacia no centro do Rio de Janeiro (o mesmo escritório responsável pela sua defesa judicial), retornando à prisão todos os dias após o expediente. No dia 30 de outubro, após cumprir mais um dia de trabalho, ao voltar para dormir no cárcere ele parou ao lado do portão do presídio de Niterói cuja fachada continha uma pichação que dizia: "Você só olha da esquerda para a direita, o Estado te esmaga de cima p/baixo". Rafael posou para uma foto e por causa disso, regrediu de regime e foi punido com 10 dias na 'solitária'. O IDDH pleiteou à Vara de Execuções Penais uma progressão de regime para Rafael Braga e em dezembro de 2015 foi permitido que ele cumprisse o restante de sua pena fora da prisão com a utilização de tornozeleira eletrônica, o que foi deferido. (...) No entanto, na manhã do dia 12 de Janeiro de 2016, Rafael foi preso por Policiais da Unidade de Policia Pacificadora na Vila Cruzeiro por tráfico de drogas e associação ao tráfico, quando ia da sua casa para a padaria. Segundo a versão dos policiais, ele carregava consigo $0,6 \mathrm{~g}$ de maconha e 9,3g de cocaína com 'etiquetas' que faziam referência ao Comando Vermelho, facção criminosa que detém o monopólio do tráfico de varejo na região. Ele teria confessado informalmente e então foi encaminhado novamente à delegacia policial em flagrante. Até hoje, ele se encontra preso por essa acusação. Ocorre que Rafael, quando ouvido, não só negou as acusações como apontou tortura e intimidação por parte dos policiais, os
} 
Vergonhoso como o próprio método de (tentativa de) extinção da multidão da rua, o caso do Rafael Braga é uma excrescência processual, considerando que o próprio laudo pericial do Esquadrão Antibombas da Polícia Civil confirmou a ausência de potencialidade lesiva dos produtos de limpeza que estavam em posse do nunca manifestante, preto, pobre, desempregado e favelado, Rafael Braga.

Aos poucos, a cisão entre manifestante pacífico e violento foi estrategicamente pensada para a identificação do inimigo, produzindo uma falsa necessidade de disciplina e controle, pautadas na identificação do violento ora "com a figura socialmente naturalizada do criminoso desprovido de direitos como caso emblemático mencionamos os dois processos de Rafael Braga -, ora identificando os Black Blocs como um coletivo" ${ }^{147}$ merecedor de perseguição policial, especialmente atrás de um líder que, necessariamente, não existe e nem deve existir dentro da tática (vide item 3.1).

2013 foi o ano que "nunca acabou" - e que talvez nunca acabe -, o ano que marcou grande parcela de pessoas em todas as áreas - advogados, socorristas, midialivristas - enquanto sujeitos daquela multidão, denunciando os abusos do poder constituído e, enquanto profissionais, na luta contra os abusos compatíveis apenas com uma política criminal autoritária adotada pelo Estado ${ }^{148}$. Os movimentos em rede, os coletivos e as táticas emergidos em 2013 fazem parte, ao

\footnotetext{
quais exigiam que ele dissesse informações referentes ao tráfico de drogas no local. Rafael afirma que o material foi plantado pelos policiais responsáveis pelo flagrante. Sua vizinha, Evelyn Barbara, em depoimento prestado à Justiça, afirmou que viu Rafael Braga sendo abordado sozinho e sem objetos na mão. Evelyn afirmou que ele foi agredido e arrastado até um ponto longe de sua visão. O magistrado Ricardo Coronha Pinheiro, no entanto, escolheu não conferir qualquer relevância para o depoimento do réu e de sua vizinha, testemunha ocular da prática arbitrária policial. Pelo contrário, amparou uma condenação de 11 anos apenas e tão somente nas palavras dos policiais cuja conduta foi extremamente contestada.” CONRADO, Hysabella. Emblemático, caso Rafael Braga não choca o Brasil. Justificando, São Paulo, 26 abr. 2017. Disponível em: $<$ http://justificando.cartacapital.com.br/2017/04/26/emblematico-caso-rafael-braga-nao-choca-obrasil/>. Acesso em: 22 mai 2017.

Sentença disponível em:

$<\mathrm{http} / / /$ www1.tjrj.jus.br/gedcacheweb/default.aspx?GEDID=00040DF0FF64CDE7A6B8EAFE5F 0FDFEB80C5E6C50621360E >. Acesso em: 22 mai. 2017.

${ }^{147}$ CORREA, 2014, p. 176.

${ }^{148}$ Pessoalmente, não é possível lembrarmo-nos dos levantes e a sua violenta repressão sem ressentirmos um turbilhão de emoções. Algumas situações que jamais desejaremos reviver, mas que certamente não deixarão nossos corpos e mentes; outras situações que igualmente fazem parte de nós, porém despertando um sentimento acolhedor, que nos dá lembranças que desejamos manter aquecidas para, a qualquer momento (que esperamos que virá), vivê-las novamente, na experiência sempre nova, transformadora e potente das lutas nas ruas.
} 
nosso ver, das lembranças que devem ser mantidas aquecidas, prontas para tornálas reais novamente ${ }^{149}$.

\section{1.}

\section{Movimentos em rede, coletivos e táticas}

As redes sociais da internet, longe do alcance da monopolização e manipulação da grande mídia promoveram a interação e conexão de pessoas e suas vozes, múltiplas e difusas, com "preocupações reais de pessoas reais na experiência humana real que fora reivindicada". As dores e esperanças do real foram compartilhadas nas redes de internet, conectando indivíduos múltiplos que formaram redes de apoio, de troca, de solidariedade, independentemente de origens, ideologias ou filiações ${ }^{150}$.

Neste espaço virtual, autônomo e livre, os movimentos em rede de 2013 venceram o medo ${ }^{151}$ do poder constituído e lançaram-se às praças, às ruas, às cidades, espalhando-se "por contágio num mundo ligado pela internet sem fio e caracterizado pela difusão rápida, viral, de imagens e ideias" $" 152$.

\footnotetext{
149 “As Jornadas de Junho demonstraram que a multidão existe - e excede. Desperta esperanças, estimula desejos, produz comunidade, devém insurgente. Multiplicidade de singularidades em permanente recomposição, a 'plebe' jovem experimentou nas manifestações seu 'devir-multidão', afirmou-se como parcela dos sem parte que recusa não ter parte na riqueza socialmente produzida por ela. E, ao mesmo tempo, mostrou ser a única força capaz de produzir uma outra "pólis' possível, com outros valores, apontando para a instituição de uma ordem comum, participada." PILATTI, 2016b, p. 10.

${ }^{150}$ CASTELLS, 2013, p. 7.

${ }^{151}$ Entendemos aqui, assim como Castells, o medo como "emoção paralisante em que os poderes constituídos se sustentam para prosperar e se reproduzir, por intimidação ou desestímulo - e, quando necessário, pela violência pura e simples, seja ela disfarçada ou institucionalmente aplicada." Ibid., p. 8.

${ }^{152}$ Ibid. "A intensidade e a extensão do dissenso entre a multidão constituinte e os poderes constituídos encontravam expressão no slogan difundido a partir do MPL paulistano: 'por uma vida sem catracas'. Era todo um quadro de denegação de direitos que se começava a contestar por meio de variadas formas de expressão e articulação, que evidenciavam a tomada da palavra por parte de uma multiplicidade de atores: manifestantes autônomos, membros de organizações e coletivos já constituídos ou que se constituíam em torno das manifestações. Polifonia e policromia; auto-organização dos coletivos; autoconvocação das manifestações por meio de compartilhamentos realizados nas redes sociais pelos ativistas independentemente dos promotores da convocação inicial; inexistência de centro, liderança ou hierarquia reconhecidos; exigência de horizontalidade nas ações e deliberações: tudo isso traduzia a forma multitudinária do levante, a afirmação da potência constituinte de uma multidão jovem cujo corpo ia se construindo pelo incessante trabalho de composição, estranhamento e recomposição que marcaria as diversas fases do processo." PILATTI, 2016b, p 6.
} 
Segundo Castells, a estrutura de redes abertas reduz a vulnerabilidade a ações repressivas do poder constituído, "já que há poucos alvos específicos a reprimir" ${ }^{\prime 53}$. De fato, no caso dos levantes no Rio de Janeiro, a partir de junho de 2013, a repressão direcionada “aos 23” (item 3.2.3) ocorreu depois da criação, por parte do poder constituído, que escolheu líderes nas ruas (considerados como inimigos), com vistas a arrefecer os ânimos da multidão ao demonstrar o que acontece com os resistentes ao status quo.

Os movimentos de 2013 foram espontâneos e desencadeados por uma indignação, passando desta fase para a esperança por meio de deliberação no espaço de autonomia, apresentando, assim, as características que Castells apresenta para os movimentos em rede. É também por isso que não estavam dispostos a se tornarem um partido político, porque "propõem e praticam a democracia deliberativa direta, baseada na democracia em rede" ${ }^{154}$, tendo sido fundamental a sua outra característica apontada por Castells, o companheirismo ${ }^{155}$.

Em regra, não foram violentos, pois como Castells coloca, é fundamental sustentarem sua legitimidade ante a sociedade que representam enquanto multidão, sendo notório, como fora no caso do Rio de Janeiro (até determinado momento), que as imagens de repressão violenta - por parte do poder constituído - contra os manifestantes e ocupantes acabam ampliando os movimentos e seus simpatizantes. De outro lado, igualmente a arbitrariedade e a impunidade da violência promovida pelo estado dão ensejo "a ação violenta de grupos pequenos e determinados, prontos a confrontar o sistema com violência, a fim de expor o seu caráter violento" ${ }^{, 156}$. Soma-se a isso, no caso do Rio de Janeiro, o fato de as manifestações terem sido dispersas com extrema violência, muitas vezes em razão de ações violentas da própria polícia, através de policiais militares infiltrados, chamados "P2" 157 .

\footnotetext{
${ }^{153}$ CASTELLS, 2013, p. 160.

${ }^{154} \mathrm{Ibid}$.

155 "É pelo companheirismo que as pessoas superam o medo e descobrem a esperança". Ibid., p. 163.

${ }^{156}$ Ibid., p. 165.

${ }^{157}$ Existem vídeos que comprovam essa tática da polícia. Vide: "Sequencia mostra ação dos PM infiltrados até a sua identificação". Disponível em: <https://youtu.be/hSIWIVU0deE $>$. Acesso em: 25 mai. 2017.
} 
O ambiente progressivamente repressivo nas ruas de 2013 promoveu a mobilização de algumas classes profissionais que se voluntariaram para colaborar com suas atividades de forma eficaz, como fizeram muitos profissionais de saúde (socorristas), da imprensa alternativa (midialivristas) e advogados.

A criação de coletivos de advogados e estagiários de Direito ocorreu de maneira semelhante à dos movimentos em rede: encontros nas ruas e a realização de repentinas assembleias com vistas a traçar estratégias mínimas contra a repressão violenta e autoritária que aumentava a cada manifestação. Assim, nos juntamos de forma absolutamente horizontal e solidária, dividindo-nos nas diversas delegacias da cidade, encarando todas as formas de violência contra a liberdade de expressão e de manifestação.

Muitos advogados se voluntariaram, alguns coletivos já existentes e outros criados ali, de forma espontânea e solidária. Referimo-nos aqui, especialmente ao Grupo Habeas Corpus ${ }^{158}$.

158 Participei deste grupo enquanto advogada criminalista, colaborando minimamente nas madrugadas, na tentativa de participar da luta democrática contra os abusos cometidos sistematicamente nas ruas e nas delegacias.

"O surgimento do grupo ocorreu em 15 de junho de 2013 através de uma página na rede social Facebook, tomando corpo após a mobilização de advogados voluntários no Estado de São Paulo, através da criação do grupo Habeas Corpus - MPL, em que se discutia a possibilidade de impetrar um habeas corpus preventivo para uma manifestação que iria ocorrer na cidade de São Paulo. No Rio de Janeiro, em razão de evidente necessidade de amparo dos direitos constitucionalmente garantidos (e ignorados) e da carência, nas ruas, de órgãos públicos com essa missão institucional, advogados, movidos apenas por seus ideais e em trabalho voluntário, decidiram interceder pelo cumprimento da ordem legal.

Tamanho empenho em resguardar um Estado que pertence ao povo e que para ele deveria estar direcionado (governado para um bem comum) pôde ser traduzido na assistência àqueles que lutariam no asfalto para tanto: foi impetrado um remédio constitucional preventivo para esses cidadãos. Acontece que, em menos de vinte e quatro horas após a sua criação, a página (do Estado do Rio de Janeiro) já possuía quase mil seguidores, embora nem todos fossem advogados (mas todos sedentos pelo respeito ao mínimo necessário para uma existência decente).

A partir de então, o grupo passou a contar com apoio da Ordem dos Advogados do Brasil - Seção do Rio de Janeiro (OAB/RJ) e da Caixa de Assistência dos Advogados do Estado do Rio de Janeiro (CAARJ). A primeira reunião ocorreu em 17 de junho do corrente ano, e, no mesmo dia, o grupo estreou nos manifestos na posse de uma faixa onde lia-se "ADVOGADOS", posicionandose entre os manifestantes e a Tropa de Choque da Policia Militar do Estado do Rio de Janeiro. (...)

O grupo Habeas Corpus Rio de Janeiro atua pela garantia dos ditames legais e constitucionais durante as manifestações sociais basicamente através da mediação de situações conflituosas entre manifestantes e policiais, com o acompanhamento de detenções nas ruas e orientação jurídica nas Delegacias nesse primeiro momento, apenas.

A legitimidade desse coletivo advém da árdua e constante atuação em manifestações, estando sempre atento a abusos e truculências nas situações conflituosas. O comprometimento com a defesa das garantias e direitos constitucionais por advogados voluntários e a seriedade do trabalho desenvolvido resultaram no reconhecimento e prestígio desses profissionais perante a sociedade. $\mathrm{O}$ coletivo não só foi espectador dos descomedimentos dos policiais, como também foi alvo desses excessos em incontáveis situações. Dentre as condutas violadoras tem-se o desrespeito evidente a 
Não fosse o apoio da Ordem dos Advogados do Brasil - Seção do Rio de Janeiro $(\mathrm{OAB} / \mathrm{RJ})$ e da Caixa de Assistência aos Advogados do Rio de Janeiro (CAARJ), tanto como instituições de classe na facilitação e colaboração das ações voluntárias, quanto incentivadoras do trabalho realizado, que deu credibilidade ${ }^{159}$ a todos os grupos de advogados voluntários surgidos naquele momento, muito mais advogados teriam sido agredidos.

É por esta mesma razão que muitos destes jovens - pretos, pobres, favelados -, em razão da recém acessada (por eles) rede mundial de computadores, ao tomarem conhecimento da tática black bloc ${ }^{160}$, utilizaram-na para não desaparecerem. Reutilizada nos movimentos em rede iniciados em 2011,

garantias penais, à integridade física dos manifestantes e advogados, direito de locomoção, de reunião pacífica e de liberdade de expressão." Trecho extraído do "Relatório preliminar de violações de Direitos Humanos pelo Sistema de Justiça Criminal ocorridas nas manifestações populares da cidade do Rio de Janeiro", enviado à Secretaria de Direitos Humanos da Presidência da República, da qual o grupo recebeu Menção Honrosa do Prêmio Direitos Humanos 2013, em dezembro do mesmo ano.

159 "Tal como os levantes da multidão recuperaram a importância política do Rio, fazendo-o voltar a ser a capital cívica do País (e só por isso o(a)s bravo(a)s desobedientes já merecem a gratidão de todos os cariocas), assim também o(a)s advogado(a)s que defendem as liberdades públicas nas manifestações resgataram a posição da OAB-RJ como uma das pontas de lança na defesa da cidadania e do dissenso democrático. Reunido(a)s em diversos grupos e até individualmente como 'franco-atiradore(a)s' do bom Direito, dezenas de advogado(a)s de diversas gerações trabalham pesado há dois meses nas ruas e DPs - um esforço voluntário, gratuito, corajoso e incansável. Como não poderia deixar de ser, atraíram com isso a antipatia do poder. $\mathrm{E}$ os escribas amestrados da mídia monopolista já começam a destilar seu ódio mercenário sobre ele(a)s e a entidade que os congrega. Na contramão, pra variar, do que acontece na rua: dia desses brincava com o grande amigo Ronaldo Cramer, um dos dedicadíssimos coordenadores do plantão mais querido do Rio, dizendo-lhe que ele(a)s, com sua atuação abnegada, conseguiram o milagre de fazer a galera intrépida ter simpatia por engravatados... A OAB e seus associados estão nas ruas para defender a integridade física, moral e psíquica de todos os cidadãos, suas liberdades de reunião e expressão, seus direitos civis. Inclusive dos que, mesmo pacíficos e pelo simples fato de estarem nas ruas agindo politicamente, precisam das máscaras porque têm justo receio de retaliações por parte de patrões, pais e, nos morros e subúrbios, milicianos, policiais e outros donos do pedaço. Não tenho procuração dele(a)s, nem ele(a)s precisam, mas faço questão de dizer: tenho orgulho desse(a)s Colegas, fico encantado com seu desprendimento e disponibilidade, sinto-me honrado por ser inscrito na OAB-RJ. Ele(a)s me representam. E contam com meus irrestritos apoio e solidariedade." PILATTI, Adriano. Texto retirado de postagem no Facebook. 18 ago. 2013.

No mesmo sentido: "SOLIDARIEDADE AOS QUE PROMOVEM JUSTIÇA: Ofereço a minha irrestrita solidariedade aos companheiros do Grupo Habeas Corpus e a todos os advogados que, nas ruas, com o seu talento e a sua coragem, defendem a Constituição, as leis e a democracia. E impedem, ou tentam impedir, as prisões arbitrárias e o massacre de manifestantes. $\mathrm{O}$ jornalismo menor e ideológico jamais conseguirá entender isto. Acho que cabe à $\mathrm{OAB} / \mathrm{RJ}$ um desagravo público a esses bravos colegas". DAMOUS, Wadih. Texto retirado de postagem no Facebook. 18 ago. 2013.

160 "Os Black Blocs são compostos por agrupamentos pontuais de indivíduos ou grupos de pessoas formados durante uma marcha ou manifestação. A expressão designa uma forma específica de ação coletiva, uma tática que consiste em formar um bloco em movimento no qual as pessoas preservam seu anonimato, graças, em parte, às máscaras e roupas pretas. [...]. O principal objetivo de um Black Bloc é indicar a presença de uma crítica radical ao sistema econômico e político." DUPUIS-DÉRI, 2014, p. 10. 
mas conhecida na Europa desde a década de 1980, a tática os permitia insurgir-se e defender-se das ações violentas do poder constituído, sem, contudo, permitirem serem identificados: "a recusa ativa do rosto em proveito das singularidades irredutíveis de um corpo social criativo, múltiplo, nômade, potente, inclassificável" "161 é para liberarem-se do controle do Estado.

A tática black bloc não é, assim como outras estratégias, sinônimo de um movimento. Pensada na Alemanha nos anos 1980, inicialmente a tática consistia em um comportamento de autodefesa de jovens que, vestidos com máscaras e roupas pretas, adotaram contra os ataques policiais às ocupações e aos espaços de autonomia existentes na luta antinuclear ${ }^{162}$. Posteriormente, nos anos 1990, adotada nos Estados Unidos em defesa de movimentos antiglobalização, passou a atacar símbolos do capital global, iniciando "uma dimensão de violência simbólica que marcaria profundamente a tática a partir de então"163.

As jornadas iniciadas em maio e junho de 2013, em São Paulo e no Rio de Janeiro $^{164}$, deram visibilidade no país à tática black bloc, antes pouco ou totalmente desconhecida no Brasil, agora amplamente divulgada, alvo de muitas críticas em razão das ações que causaram pequenos danos patrimoniais - a qual entendemos como uma resposta à violenta repressão policial direcionada aos movimentos $^{165}$.

${ }^{161}$ CORREA, 2014, p. 181.

${ }^{162}$ SANTOS, 2014, p. 188.

${ }^{163}$ FIUZA, Bruno. Black Blocs: A origem da tática que causa polêmica na esquerda. Viomundo, São Paulo, 8 ago. 2013. Disponível em: <http://www.viomundo.com.br/politica/black-blocs-aorigem-da-tatica-que-causa-polemica-na-esquerda.html>. Acesso em: 22 mai. 2017.

164 "No Rio, a multiplicidade de atores que interagiam nas ruas era um exemplo expressivo do que se passava em outras cidades: organizações e coletivos estudantis; organizações e coletivos ligados a partidos de esquerda como o PCB, o PC do B, o PSTU e - expressando uma forte contradição interna - o PT, aliado dos governos carioca e fluminense; organizações sindicais e categorias profissionais que iam dos petroleiros aos professores e bombeiros; movimentos de sem teto, de sem terra e de ameaçados por remoções; coletivos feministas e LGBTs; movimento negro; coletivos de orientação libertária; jovens secundaristas uniformizados, jovens manifestantes autônomos de rosto descoberto, jovens manifestantes mascarados adeptos da chamada tática black bloc etc. Com o desencadeamento da repressão, foram também se formando ou ampliando coletivos e redes de advogados ativistas, de socorristas da área de saúde, de midiativistas etc" PILATTI, 2016b, p. 9.

165 "A seu modo, os black blocs exercitam singularidades nas manifestações coletivas, protegendo as diferentes ações de ruas e se voltando para o confronto exclusivamente com a violência institucionalizada." PASSETTI, Edson. A ação direta contra o insuportável. Revista Verve, $\mathrm{n}^{\circ} 26$, ano 2014, p. 206. Disponível em: $<$ https://revistas.pucsp.br/index.php/verve/article/view/30791/21310>. Acesso em: 25 mai. 2017. 
No Rio de Janeiro, a tática mostrou-se pela primeira vez enquanto "bloco negro" no dia 30 de junho de 2013, embora dez dias antes, no levante de mais de um milhão na Avenida Presidente Vargas, anarquistas já conhecedores de táticas de resistência tenham protegido manifestantes da chuva de bombas e balas de borracha. Tal ação contagiou outros que tomaram atitudes semelhantes, de forma solidária, aderindo àquela tática ${ }^{166}$ que parecia embrionária ao que surgiria em seguida no Rio.

Os black blocs cariocas protegeram os movimentos de rua, colocando-se em confronto direto com a polícia enquanto fosse possível resistir. No dia 15 de outubro, chegaram a combinar que somente reagiriam a "eventuais" agressões policiais, já que o protagonismo daquele dia era a reivindicação dos professores ${ }^{167}$. Assim foi feito, respondendo os black blocs somente e literalmente em autodefesa, em que pese no mesmo dia mais de 200 manifestantes terem sido presos ilegalmente ${ }^{168}$.

Igualmente fizeram resistência como aquela tática inicialmente pensada: protegeram os movimentos de ocupação que ocorreram na cidade, como o "Ocupa Cabral", ocupação contra o governo de Sérgio Cabral (por razões hoje ainda mais óbvias) e o "Ocupa Câmara", ocupação de professores e alunos em greve por salário digno e melhorias nas condições de ensino.

\footnotetext{
${ }^{166}$ No dia 20 de junho, “(...) depois que começou a confusão na Prefeitura e o Choque avançou, um grupo de manifestantes começou a arrancar com as mãos uma propaganda da Coca-Cola imensa, antes do sambódromo, e aquele tinha sido o dia onde tinha mais gente de verde e amarelo e cara pintada, gritando 'O gigante acordou', (...) e esses começaram a gritar o 'Sem vandalismo, sem vandalismo', enquanto os caras arrancavam o gigante anúncio na horizontal, quando, de uma hora para outra as bombas começaram a explodir mais perto e a galera correu, quando viu o Choque chegando. Os caras de preto e com máscaras atravessaram nas pistas aquele anúncio e começaram a atear fogo, para segurar o avanço do batalhão que vinha como sempre, sem piedade. Foi a salvação pro pessoal escapar. Depois daquele dia muita gente entendeu pra que serviam as tais táticas." MEIJUEIRO, 2014, p.70.

167 "A organização interna dos Black Blocs é similar à de todos os grupos anarquistas: igualitária, libertária e sem hierarquias. As decisões são tomadas coletivamente, através de deliberações, e todos os membros podem fazer propostas e discutir as propostas de outros membros. Dentre essas decisões tomadas, está o uso ou não da violência durante uma manifestação." PORTUGAL, 2016.

${ }^{168}$ Que entre os black blocs estão ou pretendem estar policiais infiltrados, provocadores, nazistas transvestidos de preto, não há novidade alguma. A inovação decorre das medidas de prisões preventivas antes das grandes mobilizações e do aumento do aparato de contenção policial violento cada vez mais sofisticado e enriquecido para combater o novo terrorista. "Ao longo dos anos, agências de inteligência e a polícia, assim como alguns acadêmicos, conseguiram construir publicamente a imagem do 'anarquista criminoso' como uma ameaça à segurança pública ou pior - um prototerrorista, quando não um verdadeiro terrorista.” PASSETTI, 2014.
} 
A tática black bloc mais difundida, consistente no ataque a símbolos do capitalismo como forma de resistência foi também utilizada pelos táticos cariocas com um "objetivo comum: apontar as diversas violações de direitos que os megaeventos e megaempreendimentos significavam para boa parte da população"169.

Quanto mais difundida a tática, maior a repressão desproporcional do poder constituído, criminalizando o exercício da democracia absoluta, transformando a resistência e os resistentes em inimigos que devem ser combatidos por meio de medidas especialmente instrumentalizadas para essa "guerra" $" 170$.

\section{2.}

\section{Os mecanismos legais e extralegais de repressão}

O primeiro ato significativo contra o aumento nas passagens de ônibus do Rio de Janeiro, em 10 de junho de 2013, foi "dispersado" com uso de bombas de efeito moral e algumas detenções. No segundo ato, ocorrido no dia 13, os advogados estavam lá, minimamente organizados, muito mais para se solidarizarem com os estudantes contra os abusos financeiros e sociais do governo do estado do Rio de Janeiro - hoje evidenciados, por meio da não menos merecedora de críticas, Operação Calicute $^{171}$ - e para garantir que ninguém

\footnotetext{
${ }^{169}$ SANTOS, 2014, p. 188.

170 'Dupuis-Déri alerta para a crescente consolidação de uma 'política da paz' composta pelos porta-vozes de movimentos progressistas, conectando-se a políticos e elites, submetendo-se a serem esquadrinhados para desfiles e funcionando, diremos, como pastores do rebanho que segue os acordos negociados previamente (...)". PASSETTI, 2014.

${ }_{171}$ Operação deflagrada pela Polícia Federal, oriunda de investigação sobre desvio de recursos públicos federais através de grandes obras realizadas no Rio de Janeiro. "A partir do aprofundamento das investigações dos casos da Lava Jato no Rio de Janeiro, especialmente da Operação Saqueador e das colaborações de executivos das empreiteiras Andrade Gutierrez e Carioca Engenharia, entre outras provas colhidas, descortinou-se amplo esquema de corrupção e lavagem de dinheiro. Tal esquema consubstanciava o pagamento de expressivos valores em vantagem indevida por parte das empreiteiras ao ex-governador Sérgio Cabral e a pessoas do seu círculo para que fossem garantidos contratos de obras com o Governo do Estado do Rio de Janeiro. As investigações apontam para a prática de corrupção na contratação de diversas obras conduzidas no governo de Sérgio Cabral, entre elas, a reforma do Maracanã para receber a Copa de 2014, o denominado PAC Favelas e o Arco Metropolitano, financiadas ou custeadas com recursos federais.” Ver mais em: Lava Jato: MPF aprofunda investigações sobre organização criminosa liderada por Sérgio Cabral. Site MPF, 17 nov. 2016. Disponível em:
} 
subtraísse os seus direitos de livre manifestação, do que para atender a manifestantes presos, como acabou ocorrendo dali em diante ${ }^{172}$.

Afinal, quem imaginava que a repressão policial alcançaria as proporções que alcançou, progressivamente, neste e nos dias subsequentes? No dia 17 de junho os ares do Estado autoritário já pesavam sob os corpos. Com a tentativa de invasão da ALERJ (Assembleia Legislativa do Rio de Janeiro), onde o Grupo Habeas Corpus já estava formado, contando com o apoio da $O A B / R J$ e da CAARJ, muitos advogados experimentaram pela primeira vez os efeitos do gás lacrimogênio e do spray de pimenta. A repressão perpetrada pela Polícia Militar já contava com o apoio midiático e institucional. Em nossos canais de comunicação virtual descrevíamos incrédulos o cenário que jamais imaginaríamos. Até que o dia 20 de junho chegou.

Um milhão de pessoas na Avenida Presidente $\operatorname{Vargas}^{173}$, uma certa confusão entre protestantes após claras tentativas de cooptação, pela direita, dos protestos da multiplicidade, uma aterrorizante perseguição aos manifestantes no final daquele dia, e notícias veiculadas tão somente dando enfoque a poucas depredações ocorridas naquele dia que marcou definitivamente as jornadas de 2013. Havia um pelotão com uma faixa extensa escrita: "ADVOGADOS". Eram os advogados do Grupo Habeas Corpus, os representantes de Comissões da OAB/RJ e integrantes da CAARJ ${ }^{174}$, os do IDDH $^{175}$, da ONG JUSTIÇA GLOBAL, entre tantos outros colegas que passavam aderindo à marcha, e populares aplaudindo aquela formação em defesa de direitos fundamentais.

\footnotetext{
$<$ http://www.mpf.mp.br/rj/sala-de-imprensa/noticias-rj/lava-jato-mpf-aprofunda-investigacoessobre-organizacao-criminosa-liderada-por-sergio-cabral>.Acesso em: 24 mai. 2017.

172 "Desde o início, a violência do Estado vinha sendo a mais autêntica e constante resposta dos poderes constituídos às manifestações, e a repressão agigantou-se na mesma proporção do crescimento do número de manifestantes entre a segunda e a terceira semana de junho. As autoridades pareciam ter entregado às forças policiais a 'mediação' do dissenso instaurado nas ruas, mas não era só aparência: o uso indiscriminado de uma violência cada vez mais intensa e brutal contra manifestantes generalizou-se, a infiltração de agentes policiais no movimento se alastrou, e a violação de sigilo das comunicações telefônicas e informáticas de ativistas, apoiadores e advogados tornou-se uma constante, induzindo a adoção de novos padrões de comunicação entre eles. Nos circuitos discursivos oficialistas e governistas iniciou-se também uma ofensiva de desqualificação dos manifestantes e de seus apoiadores, só comparável à da mídia e da imprensa comerciais, contribuindo assim para os esforços de legitimação da criminalização dos manifestantes e de seus atos de resistência e desobediência." PILATTI, 2016b, p. 14.

${ }^{173}$ Fonte: http://odia.ig.com.br/noticia/rio-de-janeiro/2014-06-06/ha-um-ano-comecava-onda-deprotestos-na-cidade.html

${ }_{174}^{174}$ Caixa de Assistência dos Advogados do Estado do Rio de Janeiro.

${ }^{175}$ Instituto de Defensores de Direitos Humanos.
} 
Pela primeira vez eram muitos advogados e, com as muitas bombas e correria, reuniram-se na sala da CAARJ, formando um verdadeiro "QG" para defesa dos direitos fundamentais que incrivelmente eram violados com a chancela do poder constituído. Ali dividiram-se em subgrupos, lançaram-se às ruas em busca de manifestantes encurralados, fizeram ligações a diversas delegacias, dividiram táxis para dar tempo de socorrer os manifestantes. Um empenho coletivo que aumentava na medida em que chegavam as notícias de encurralamento de manifestantes em bares, restaurantes, becos e até em dois campi da Universidade Federal do Rio de Janeiro ${ }^{176}$. Em cada lugar se faziam presentes com uma indignação que contagiou todos os envolvidos, o que proporcionou o aumento expressivo de integrantes do Grupo nos dias subsequentes.

Embora conhecidos de longa data pela militância criminal e dos movimentos sociais, os abusos policiais das jornadas de 2013 foram cometidos de forma assustadoramente explícita, não tão devastadoras quanto são nas favelas onde tudo se faz às claras, porém sem a luz da publicidade e sem bala de borracha - mas com extrema violência e, principalmente, com aval do aparato estatal, publicidade da grande mídia e, lamentavelmente, com o apoio de muitos cidadãos telespectadores daqueles programas televisivos.

Esse estado policial protagonizou, nas jornadas de junho 2013, momentos em que manifestantes $\operatorname{presos}^{177}$ ficaram incomunicáveis dentro da unidade policial, mesmo com a ação insistente dos advogados na defesa dos seus direitos fundamentais. Por diversas vezes, os jovens presos saíam do local da sua apreensão e não sabiam para onde seriam levados. Nestes casos, igualmente desconhecedores dos destinos dos presos, os advogados chegavam nas delegacias às cegas, a procura de seus defendidos, ou até mesmo de maneira antecipada, já intuindo alguns destinos, lá esperavam os primeiros a chegarem.

Após detidos, muitos circulavam por horas em viaturas, sem qualquer informação a respeito do local aonde estavam sendo conduzidos, ou por quem

\footnotetext{
${ }^{176}$ No Instituto de Filosofia e Ciências Sociais (IFCS-UFRJ) e na Faculdade Nacional de Direito (FND-UFRJ), cerca de 700 alunos ficaram encurralados.

${ }^{177}$ No tumulto, a PM prendia moradores de rua, pessoas aleatórias que só estavam ali na "hora errada", inclusive pessoas com deficiência e, claro, manifestantes que exerciam os seus direitos fundamentais de liberdade de expressão e de manifestação.
} 
estavam sendo levados ${ }^{178}$, sem os seus aparelhos de telefone celular - ilegalmente apreendidos -, sem contato com qualquer advogado, sofrendo, com isso, tortura psicológica com pelo menos um objetivo: ao chegarem na delegacia eram pressionados a delatar alguns nomes que pudessem ser identificados como articuladores dos atos. Nomes estes, sabemos e já sabíamos, inexistentes, já que quem estava na rua era a multidão heterogênea com a sua voz democrática, leal e solidária.

Nas delegacias, por diversas vezes os termos de declarações dos manifestantes conduzidos- ora como presos, ora como detidos ${ }^{179}$ - eram redigidos a partir de uma inquirição tendenciosa e violenta, pois a Polícia Civil estava orientada a perguntar, por exemplo, quem financiava o manifestante então inquirido; a qual partido estariam vinculados; se, onde e quando reuniam-se para organizar os atos, etc.. A inquirição lembrava a volta ao período de Ditadura Militar, que a maioria dos voluntários nunca viveu, mas que sabia da urgência de combatê-la.

Também não foram poucas as afrontas que as advogadas ouviram dos Policiais Militares - especialmente, mas não exclusivamente, dos homens do Batalhão de Choque. Diversas ameaças veladas ${ }^{180}$, uma verdadeira violência de gênero contra a qual a resistência também era necessária, porém difícil de conciliar com a resistência às ilegalidades contra os manifestantes ${ }^{181}$. Orientavamse umas às outras e uns aos outros: "a luta é por direitos, somos profissionais e não cairemos na armadilha do Estado, não brigaremos com os policiais, brigaremos pelos direitos dos manifestantes". A postura irredutível dos advogados na defesa dos direitos dos manifestantes era, muitas vezes, interpretada como desacato, desrespeito e soberba, mesmo na ausência de atitude desrespeitosa com os agentes de repressão do Estado.

\footnotetext{
${ }^{178}$ Práxis de todas as manifestações é a presença de policiais militares sem identificação.

179 Conduzidos em razão de flagrante por crimes de menor potencial ofensivo, como dano, desacato, etc.

${ }^{180}$ Lembro-me que na $17^{\text {a }}$ Delegacia (São Cristóvão), ao acompanhar menores apreendidos na manifestação de 15 de outubro de 2013, apresentei-me a um policial - obviamente não identificado - e estendi minha mão a ele, no intuito de cumprimentá-lo e dizer que, da mesma forma que ele, eu estava ali trabalhando, porém voluntariamente. Aquele senhor apertou a minha mão com força extrema, me causando muita dor, mas o seu rosto era cínico, com um breve sorriso de prazer em me machucar. Para as pessoas em volta, ele estava apenas sendo simpático.

${ }^{181}$ Não nos era possível, no momento da defesa dos direitos fundamentais dos manifestantes, responder ou afrontar os que nos subjugavam enquanto mulheres, sob pena de maiores violações dos direitos dos defendidos. Era uma emboscada.
} 
Até a manifestação de 30 de agosto de 2013, sabiam de cerca de 3 (três) delegacias ${ }^{182}$ para as quais, em regra, eram levados os manifestantes em razão das circunscrições das unidades policiais ${ }^{183}$. Ficavam lá a sua espera em quase todas as manifestações até que, em mais uma clara tentativa de atrapalhar o trabalho voluntário dos coletivos de advogados, os manifestantes foram levados a delegacias que nada tinham a ver com a circunscrição do local das manifestações.

Fato é que os policiais que agem nas favelas com truculência e cometendo arbitrariedades não estão, mesmo, acostumados com qualquer forma de resistência - lá a bala não é de borracha - muito menos por parte daqueles que sabem os limites de uma abordagem policial. A consequência da resistência por parte dos profissionais de Direito é que não faltaram agressões físicas, psicológicas e, sobretudo, tentativas de criminalizar os advogados até que, enfim, conseguiram ${ }^{184}$.

\footnotetext{
$1825^{\mathrm{a}}$ DP (Lapa), $9^{\mathrm{a}}$ DP (Catete) e $12^{\mathrm{a}}$ DP (Copacabana).

183 "No dia 30 de Agosto os advogados voluntários do Grupo Habeas Corpus Rio de Janeiro, do Instituto de Defesa dos Direitos Humanos (IDDH) e da Ordem dos Advogados do Brasil $(\mathrm{OAB} / \mathrm{RJ})$ foram surpreendidos com a mudança de jurisdição das delegacias. A informação veio por acaso através de um PM, quando um menor de idade foi detido na escadaria da Câmara por falta de documentos. O procedimento correto seria levar o adolescente apreendido para a $5^{\mathrm{a}} \mathrm{DP}$, na Rua Gomes Freire, no Centro, mas os advogados tiveram que ir para a $21^{\text {a }} \mathrm{DP}$, em Bonsucesso. As delegacias que atuam como centrais de flagrantes, por designação e, por consequência, de conhecida rotina tanto de advogados quanto de imprensa e manifestantes (dado também os endereços onde têm ocorrido as manifestações mais recentes no Rio de Janeiro) são a $5^{\mathrm{a}}$ DP, no Centro, a $9^{\mathrm{a}}$ DP, no Catete, e a $12^{\mathrm{a}}$ DP, em Copacabana, mas no dia 30 de Agosto de 2013 os detidos foram distribuídos para a $18^{\mathrm{a}} \mathrm{DP}$, na Praça da Bandeira, a $21^{\mathrm{a}} \mathrm{DP}$, em Bonsucesso, e a $17^{\mathrm{a}}$ $\mathrm{DP}$, em São Cristóvão, sem qualquer aviso prévio ou comunicado oficial sobre a mudança e motivos das alterações. No dia 3 de setembro do corrente ano ocorreu no Centro uma manifestação denominada 'Baile das Máscaras', que visava demonstrar a inconstitucionalidade da lei estadual que proibia o uso de máscaras nos protestos. Em determinado momento houve a detenção de um manifestante e de uma advogada sob a alegação de que teriam desrespeitado ordem policial de não atravessarem a rua se manifestando. Novamente os agentes não disseram para onde seriam levados e, após trinta minutos de espera, foi noticiado que ambos estariam sendo encaminhados à $21^{\mathrm{a}}$ Delegacia de Policia, localizada em Bonsucesso, a aproximadamente $17 \mathrm{~km}$ de distância do local da suposta infração penal. Lá chegando, foram encaminhadas à $37^{a}$ Delegacia de Polícia, localizada na Ilha do Governador, situada a $13 \mathrm{~km}$ da delegacia anterior. Quando o fato foi apresentado à autoridade policial, inexistindo conduta criminosa, ambos foram submetidos a identificação criminal, através do 'SARC' e liberados em seguida. No dia $1^{\circ}$ de outubro, manifestantes abordados no Centro da cidade foram 'pulverizados', mais uma vez, para delegacias em diferentes localidades, tal qual no último dia 7 de outubro. Apesar de a circunscrição competente ser apenas a da $5^{\text {a }}$ Delegacia de Polícia, tal prática tornou-se corriqueira, instando salientar que a atual Chefe da Polícia Cívil do Estado do Rio de Janeiro, Marta Rocha, esteve presente nesse dia na referida Delegacia e ainda assim o Delegado informou aos advogados voluntários ali presentes que não iria receber manifestantes detidos naquela repartição e que seriam todos encaminhadas para outras circunscrições.” Fonte: Relatório do Grupo Habeas Corpus enviado à Secretaria de Direitos Humanos da República em outubro de 2013. Obtido por e-mail pessoal em 27 mai. 2015.

${ }_{184}$ Referimo-nos ao processo dos 23 , mais adiante enfrentado, no qual diversos advogados foram alvo de interceptação telefônica, condução à delegacia e, inclusive, denúncia por parte do Ministério Público do Estado do Rio de Janeiro.
} 
A vontade soberana de suprimir o movimento constituinte nas ruas em 2013 foi (e continua sendo) tão devastadora que o Estado tratou imediatamente de acelerar medidas ${ }^{185}$ ainda mais repressivas contra as vozes da multidão jovem que emergia nas ruas. Ao invés de abrir o diálogo, o que se espera em regimes verdadeiramente democráticos, foram aprovadas às pressas medidas legais absolutamente repressivas, como a inconstitucional CEIV - Comissão Especial de Investigação de Atos de Vandalismo, através de decreto estadual do então governador Sérgio Cabral, bem como, na esfera federal, a tramitação em regime de urgência e a sanção, pela Presidenta Dilma Rousseff, da Lei das Organizações Criminosas, ambas normas mais adiante debatidas.

Junho, julho, agosto e setembro foram meses muito intensos, de longas noites trabalhadas, muita articulação entre os voluntários para que não houvesse um só manifestante sozinho em alguma unidade policial, até que a inesquecível e determinante manifestação do dia 15 de outubro transformou a vivência das ruas.

Determinante porque houve mudança no paradigma repressivo: entendeuse, enfim, que calar a multidão não era fácil, a não ser que decidissem amedrontálas com prisões em massa, todas arbitrárias e por “crimes" inafiançáveis, típicas de Estados policiais e fascistas. No Rio, o medo se tornou decisivo a partir deste dia, no qual amontoaram manifestantes (muitos professores, inclusive) em viaturas e ônibus da Polícia Militar para, em seguida, joga-los às masmorras, isto é, os presídios no Rio de Janeiro. E assim foi feito, contando o aparato estatal com a recém vigência da Lei de Organizações Criminosas: foram mais de 200 manifestantes levados às delegacias, quase 70 presos, destes, sendo quase a metade com base nessa Lei (vide item 3.2.2).

A partir deste dia violentíssimo para a democracia, as manifestações, que antes agregavam uma multidão de muitos milhares de indivíduos, passaram a contar com cerca de mil bravos e resistentes, que apanhavam muito, eram escorraçados das ruas, mas retornavam. Nos é certo que a estratégia do Estado policial era conter os resistentes de modo que, a partir de outubro, muitas

\footnotetext{
${ }^{185}$ A malfadada Lei Antiterrorismo, de 16 março de 2016, também faz parte do pacote repressor do Estado aos movimentos de resistência. Sancionada pela presidenta Dilma, com alguns vetos e com a inclusão de parágrafo para (tentar) afastar eventual criminalização de protestos populares, a lei, de fato, não protege os movimentos sociais. Prova disso é a prisão, em abril de 2016, de 4 integrantes do MST com base na modificação que esta lei promoveu na Lei de Organizações Criminosas.
} 
manifestações sequer eram iniciadas em razão da intervenção prévia da polícia. Ao que nos parece, a menor quantidade de prisões no período de outubro a julho de 2014 relaciona-se com a estratégia adotada às vésperas da estreia da Copa, iniciada nos grandes levantes de 2013 e implementada ardilosamente através de instrumentos repressivos do Estado: a identificação de supostos líderes e de uma suposta rede de articulação

Iniciado com uma verdadeira operação policial, o denominado "processo dos 23" (item 3.2.3.) que, simbolicamente e sem nenhuma coincidência, em 13 de julho de 2014, véspera da abertura da Copa do Mundo sediada no Rio de Janeiro, determinou a prisão de 23 (vinte e três) manifestantes considerados os líderes dos movimentos de 2013, pretendeu ser - como tem sido provisoriamente - a última pá de cal jogada sob a multidão jovem que urgia por seus direitos nas ruas do Rio de Janeiro. Entre as violações de direitos mais comuns nos levantes de 2013, essas foram identificadas como as principais:

1) falta de identificação dos policiais ${ }^{186}$

2) detenções arbitrárias, como detenção para averiguação, prática extinta desde o fim da ditadura militar;

3) criminalização da liberdade de expressão por meio do enquadramento de manifestantes em tipificações penais inadequadas às ações do "infrator";

4) censura prévia, por meio da proibição, legal ou não, de manifestantes usarem máscaras ou levarem vinagre para o protesto $^{187}$;

\footnotetext{
${ }^{186}$ Embora o Ministério Público do Estado do Rio de Janeiro tenha conhecimento, desde 2013, da presença corriqueira de policiais militares sem identificação nas manifestações, enfim, em maio de 2017, obteve na justiça decisão que obriga o uso de identificação pelos PMs: "O MPRJ obteve, nesta quinta-feira $(25 / 05)$, decisão na Justiça para que policiais militares passem a adotar identificação em seus uniformes durante atuação em operações especiais, manifestações e eventos de grande participação popular. O Estado deverá, em 24 horas, tomar as providências necessárias para inserir as inscrições alfanuméricas em todos os equipamentos de uso pessoal dos PMs (farda, capacete, coletes) sob pena de multa diária de R 1 mil. Para o Grupo de Atuação Especializada em Segurança Pública (GAESP/MPRJ), a iniciativa permitirá apurar, posteriormente e se for o caso, eventual abuso de poder por parte dos policiais. (...) O MPRJ ressalta que o uso moderado da força deve nortear as operações da Polícia Militar do Estado do Rio de Janeiro e reconhece seu papel como fiscal desta atuação. Também contribuiu para a decisão os diversos eventos que vêm ocorrendo, quase que diariamente, na cidade do Rio de Janeiro e que demandam providências no sentido de se garantir o direito à livre manifestação. Assim como, notícias e vídeos produzidos em recentes protestos que comprovaram o uso imoderado da força pela Polícia Militar contra cidadãos sem qualquer envolvimento em atos ilícitos. Na manifestação do dia 28 de abril, imagens mostraram spray de pimenta e bombas sendo lançadas contra o público, inclusive durante o canto do hino nacional e na direção do palco onde os participantes faziam uso da palavra. Para o GAESP/MPRJ, a apuração dos abusos e a individualização de cada conduta, no entanto, fica prejudicada, já que a tropa vem atuando sem a identificação necessária de cada agente.” Ver mais em: MPRJ obtém decisão para que PMs usem identificação em uniformes durante manifestações. Site MPRJ, 25 mai. 2017. Disponível em: <http://www.mprj.mp.br/web/guest/home/-/detalhenoticia/visualizar/41301>. Acesso em: 26 mai. 2017.

${ }^{187}$ Em 11 de setembro de 2013, o ex-governador Sergio Cabral sancionou a Lei no 6.528 que, “a pretexto de regulamentar dispositivo da constituição fluminense relativo às liberdades de reunião e
} 
5) uso de armas letais e abuso das armas menos letais;

6) esquema de vigilantismo nas redes sociais montado pelas polícias locais, pela Abin e também pelo Exército; assim como as gravações realizadas pelos policias durante os protestos;

7) desproporcionalidade do efetivo disposto para o policiamento do protesto com o número de manifestantes;

8) policiais infiltrados nas manifestações que, por vezes, causavam e incentivavam tumulto e violência;

9) maior preocupação policial com a defesa do patrimônio do que com a segurança e integridade física dos manifestantes;

10) ameaças e até mesmo sequestros foram relatados. ${ }^{188}$

Acrescentamos, porém, as constantes violações das prerrogativas dos advogados durante as abordagens policiais nas ruas e nas delegacias. Vale lembrar que, enquanto profissionais no exercício da profissão, os advogados são essenciais ao funcionamento da justiça.

A instrumentalização do Estado a fim de reprimir violentamente os levantes iniciados em junho de 2013 não tem a pretensão de esconder o real intuito: a manutenção do status quo. Prova disso foi a decretação de medida pelo governo fluminense que determinou a criação de comissão para apurar e reprimir "atos de vandalismo", sem que tal ação tenha previsão típica na legislação penal brasileira, além de ser demasiadamente vaga, justamente para que a abrangência do seu conceito jurídico-normativo fosse uma carta branca aos agentes de repressão.

\subsection{1.}

\section{Comissão Especial de Investigação de Atos de Vandalismo - CEIV}

manifestação, proibia o 'uso de máscaras ou qualquer forma de ocultar o rosto do cidadão com o propósito de impedir-lhe a identificação'. A constitucionalidade da famigerada Lei (...) chegou a ser questionada em ação proposta pelo Conselho Seccional da Ordem dos Advogados do Brasil no Rio de Janeiro, tendo o Instituto de Advogados Brasileiros como amicus curiae, e sua eficácia foi reiteradamente posta em dúvida por muitos delegados de polícia que liberaram manifestantes detidos pela PM a pretexto de seu desrespeito. Mas o Tribunal de Justiça fluminense não concedeu a suspensão cautelar de sua vigência, requerida pela OAB-RJ, e só foi se manifestar sobre o mérito em novembro do ano seguinte, declarando-a constitucional face à Constituição do Estado. $\mathrm{O}$ objetivo da 'Lei Brazão' era obviamente inibir e reprimir os adeptos da tática black bloc, que cobriam seus rostos durante as ações de autodefesa e ocupação que exercitavam nas ruas." PILATTI, 2016b, p.19.

188 ARTIGO 19. Protestos no Brasil 2013. Disponível em: $<$ http://protestos.artigo19.org/Protestos_no_Brasil_2013.pdf>. Acesso em: 23 mai. 2017. 
O Decreto $\mathrm{n}^{\mathrm{o}}$ 44.302, assinado em 19 de julho de 2013 pelo então Governador do Estado do Rio de Janeiro, Sergio Cabral, entrou em vigor na data de sua publicação, segunda-feira, 22 de julho, e criou a Comissão Especial de Investigação de Atos de Vandalismo em Manifestações Públicas com 'superpoderes' autoritários, tendo sido apelidado por manifestantes de "DOICODI do Cabral", tamanha eram as violações que o ato do executivo permitia:

DECRETO No 44.302 DE 19 DE JULHO DE 2013

CRIA COMISSÃO ESPECIAL DE INVESTIGAÇÃO DE ATOS DE VANDALISMO EM MANIFESTAÇÕES PÚBLICAS - CEIV E DÁ OUTRAS PROVIDÊNCIAS.

O GOVERNADOR DO ESTADO DO RIO DE JANEIRO, no uso de suas atribuições constitucionais e legais, CONSIDERANDO

- os recentes e reiterados acontecimentos envolvendo atos de vandalismo perpetrados por grupos organizados, causadores de danos a incolumidade física de pessoas e destruição do patrimônio público e privado, e

- a necessidade de as instituições públicas incumbidas da defesa do Estado Democrático de Direito se organizarem para promover uma maior eficiência na investigação e na tomada de providência para a prevenção da ocorrência de novos atos de vandalismo e punição das práticas criminais já perpetradas

DECRETA:

Art. $1^{\circ}$ - Fica instituída a Comissão Especial de Investigação de Atos de Vandalismo em Manifestações Públicas - CEIV, a ser composta por representantes das seguintes instituições

a) Ministério Público do Estado do Rio de Janeiro,

b) Secretaria de Segurança do Estado do Rio de Janeiro,

c) Polícia Civil,

d) Polícia Militar

$\S 1^{\circ}$ - Os Chefes das Instituições mencionadas neste artigo indicarão os integrantes da Comissão, composta por tantos membros quantos por elas considerados necessários

$\S 2^{\circ}$ - A Presidência da Comissão caberá a um dos representantes do Ministério Público, indicado pelo Procurador-Geral de Justiça

$\S 3^{\circ}$ - A Comissão contará com a estrutura administrativa necessária para o seu funcionamento, devendo as suas requisições de pessoal e infraestrutura serem atendidas com prioridade

$\S 4^{\circ}$ - O Secretário Chefe da Casa Civil acompanhará os trabalhos da Comissão, podendo solicitar informações necessárias para a tomada de decisões por parte do Governador do Estado

$\S 5^{\circ}$ - A Comissão tem por finalidade a otimização dos trabalhos de investigação, não importando na alteração das competências e prerrogativas legais das instituições dela integrantes

Art. $2^{\circ}$ - Caberá a CEIV tomar todas as providências necessárias a realização da investigação da prática de atos de vandalismo, podendo requisitar informações, realizar diligências e praticar quaisquer atos necessários a instrução de procedimentos criminais com a finalidade de punição de atos ilícitos praticados no âmbito de manifestações públicas

Art. $3^{\circ}$ - As solicitações e determinações da CEIV encaminhadas a todos os órgãos públicos e privados no âmbito do Estado do Rio de Janeiro terão 
prioridade absoluta em relação a quaisquer outras atividades da sua competência ou atribuição

Parágrafo Único - As empresas Operadoras de Telefonia e Provedores de Internet terão prazo máximo de 24 horas para atendimento dos pedidos de informações da CEIV

Art. $4^{\circ}$ - Este Decreto entra em vigor na data de sua publicação

Rio de Janeiro, 19 de julho de 2013

SÉRGIO CABRAL ${ }^{189}$

O decreto do dia 19 de julho surpreendeu a OAB/RJ, a Defensoria Pública, membros do Ministério Público, movimentos sociais, juristas, manifestantes, etc.. Muitos anunciaram a sua oposição ao decreto, destacando as suas arbitrariedades, como a possibilidade de pedidos de quebra de sigilo diretamente às Operadoras de Telefonia - o que seria totalmente inconstitucional, além de tal fato constituir crime previsto em lei ${ }^{190}$; houve críticas ao prazo de até 24 (vinte e quatro) horas para as operadoras responderem as solicitações da Comissão; e ao regime de 'prioridade absoluta' aos pedidos da CEIV encaminhados "a todos os órgãos públicos e privados no âmbito do Estado do Rio de Janeiro".

Não bastasse a desigual ${ }^{191}$ determinação de "prioridade absoluta" dada pelo Decreto a qualquer pedido da CEIV, o executivo estadual não tem competência para legislar sobre formas de obtenção de provas em investigação penal, o que é matéria afeta à União, o que se repete em relação a legislação sobre Telecomunicações, de modo que a CEIV já nascera formalmente inconstitucional.

Não faltaram, por essas e outras razões, análises críticas de professores, advogados, defensores públicos, movimentos sociais, ONGs de direitos humanos e também de promotores de justiça em relação às inconstitucionalidades do decreto, até que o governador, dois dias após a publicação do decreto anterior, o revogou, substituindo-o pelo Decreto $\mathrm{n}^{\circ}$ 44.305, de 24 de julho de 2013, que, em

\footnotetext{
${ }^{189}$ Diário Oficial do Estado do Rio de Janeiro - Ano XXXIX - nº 133 - Segunda-feira, 22 de julho de 2013. “ATOS DO PODER EXECUTIVO”, p. 1.

190 Lei no 9.296/1996. Lei interceptações telefônicas: "Art. 10. Constitui crime realizar interceptação de comunicações telefônicas, de informática ou telemática, ou quebrar segredo da Justiça, sem autorização judicial ou com objetivos não autorizados em lei. Pena: reclusão, de dois a quatro anos, e multa."

${ }^{191}$ Em detrimento das investigações já em curso, ou até mesmo daquelas que poderiam ser iniciadas, ou das providências que poderiam ser tomadas quanto a fatos que, realmente, órgãos públicos de segurança deveriam zelar e para os quais o interesse público deveria ser muito maior do que investigar manifestante com rostos cobertos.
} 
verdade, criou o parágrafo único do artigo $2^{\circ}$ e alterou o parágrafo único do artigo $3^{\circ}$ do Decreto anterior, cujas redações ficaram da seguinte forma:

\begin{abstract}
ATO DO PODER EXECUTIVO
DECRETO No 44.305 DE 24 DE JULHO DE 2013 (...)

Art. $2^{\circ}$ - Caberá à CEIV tomar todas as providências necessárias à realização da investigação da prática de atos de vandalismo, podendo requisitar informações, realizar diligências e praticar quaisquer atos necessários à instrução de procedimentos criminais com a finalidade de punição de atos ilícitos praticados no âmbito de manifestações públicas.

Parágrafo Único - Observar-se-á a reserva de jurisdição exigida para os casos que envolvam quebra de sigilo.

Art. $3^{\circ}$ - As solicitações e determinações da CEIV encaminhadas a todos os órgãos públicos e privados no âmbito do Estado do Rio de Janeiro terão prioridade absoluta em relação a quaisquer outras atividades da sua competência ou atribuição.

Parágrafo Único - As empresas Operadoras de Telefonia e Provedores de Internet darão prioridade para o atendimento dos pedidos de informações formulados pela CEIV ou decorrentes de ordem judicial nos casos de sigilo previstos na legislação.

Art. $4^{\circ}$ - Este Decreto entra em vigor na data de sua publicação, ficando revogado o Decreto $\mathrm{n}^{\mathrm{o}} 44.302$, de 19 de julho de 2013.

Rio de Janeiro, 24 de julho de 2013.

SÉRGIO CABRAL ${ }^{192}$
\end{abstract}

Este novo decreto entrou em vigor três dias após o outro (25.07.2013)

e foi igualmente criticado porque, aparentemente, tentava resolver somente a questão da necessidade de decisão judicial para as quebras de sigilo telefônico e telemático junto às operadoras. Além da questão da desigualdade promovida pela "prioridade absoluta", o decreto manteve o Ministério Público (MP), que tem como uma de suas funções a garantia da aplicação das leis de maneira igualitária e imparcial, na presidência de uma Comissão que foi criada para perseguir atos de manifestantes (com prioridade), de braços dados com a Polícia Militar, instituição a quem cabe o MP fiscalizar. No dia 29 de julho, o procurador-geral de Justiça, Marfan Martins Vieira, designou os promotores e o procurador de justiça que fariam parte da Comissão:

Designa o Procurador de Justiça EDUARDO DA SILVA LIMA NETO e os Promotores de Justiça DÉCIO LUIZ ALONSO GOMES, HOMERO DAS NEVES FREITAS FILHO, LUÍS OTÁVIO FIGUEIRA LOPES, PATRICIA MOTHÉ GLIOCHE BÉZE, PAULO ROBERTO MELLO CUNHA JUNIOR e PAULO WUNDER DE ALENCAR para, sob a presidência do primeiro, integrarem a Comissão Especial de Investigação de Atos de Vandalismo em

${ }^{192}$ Diário Oficial do Estado do Rio de Janeiro - Ano XXXIX - n 136 - Quinta-feira, 25 de julho de 2013. “ATOS DO PODER EXECUTIVO”, p. 1. 
Manifestações Públicas - CEIV, instituída pelo Decreto Estadual no 44.302, de 19 de julho de 2013, como representantes do Ministério Público do Estado do Rio de Janeiro, sem prejuízo de suas demais atribuições. ${ }^{193}$

O problema mais evidente do decreto era, contudo, a expressão "atos de vandalismo", pois, sem qualquer restrição quanto ao seu conceito jurídiconormativo, que sabemos que não tem previsão típica no ordenamento jurídico brasileiro, qualquer ato durante as manifestações, poderia então ser entendido como ato de vandalismo, "passando verdadeiro 'cheque em branco' para medidas autoritárias de repressão" $" 194$ sem que haja crime tipificado para tanto.

O que se quer mostrar é o absurdo da criação da comissão que determina a instauração de procedimentos investigatórios - com ajuda da Polícia Militar, que não tem função investigatória ${ }^{195}$, mas que integrara a "Comissão de Investigação" - para apuração, repressão e prevenção de fato atípico, que não constitui crime.

Também questionável é a participação em conjunto do Ministério Público com a Polícia Militar em uma Comissão de Investigação enquanto o controle externo da atividade policial compete ao próprio Ministério Público. “O MP, em momento de crise, dará os braços à PM sem antes compreender o que está sendo feito pela PM??"196. Sim, sob o comando do Procurador Geral de Justiça, Marfan Martins Vieira, e com a ordem do então Governador Sérgio Cabral, o Ministério Público esteve sob a presidência da CEIV, criada para investigar, reprimir e prevenir atos de vandalismo - frise-se, que não são tipificados - em conjunto com a Polícia Militar.

A revogação do decreto ocorreu sob a suposta alegação ministerial de que "após dois meses de trabalho conjunto, a comissão alcançou bons resultados e cumpriu seus objetivos" ${ }^{\prime 197}$. Os resultados mencionados pelo MP

193 DIÁRIO OFICIAL DO ESTADO DO RIO DE JANEIRO. Ano XXXIX, nº 136/137. 29 jul. 2013. Parte IA: Ministério Público - Procuradoria-Geral de Justiça - "Atos do Procurador-Geral”, p. 1.

${ }^{194}$ MORAES \& MORAES, 2016, p. 102-121.

195 Art. 144, parágrafo $5^{\circ}$, da Constituição Federal.

${ }^{196}$ Promotor de Justiça Tiago Joffily em palestra ministrada na $42^{a}$ reunião do Fórum Permanente de Direitos Humanos da Escola da Magistratura do Estado do Rio de Janeiro (EMERJ): "Direito à manifestação, democracia e garantias constitucionais", em 26 de setembro de 2013. EMERJ Serviço de Áudio e Vídeo.

${ }^{197}$ MP propõe ao governo fim da comissão que apura atos de vandalismo. O Dia, Rio de Janeiro, 25 set. 2013. Disponível em: <http://odia.ig.com.br/noticia/rio-de-janeiro/2013-09-25/mp-propoeao-governo-fim-da-comissao-que-apurava-atos-de-vandalismo.html >. Acesso em: 22 mai. 2017. 
ainda não sabemos, posto que indisponíveis ${ }^{198}$, mas é de nosso conhecimento outros resultados, como a evidência de esta Comissão significar mais um mecanismo de instrumentalização do poder punitivo para conter a multidão insatisfeita e disposta a mudar o status quo.

A luta pela concretização de direitos não deveria passar pela reprimenda do direito penal, que não se presta a transformar as coisas, mas que exerce um papel de instrumento de controle social para manter o status quo, isto é, riquezas e desigualdades. Mas a luta legítima não tem sido bem aceita pelo poder instituído, que tem se valido de instrumentos para conter essa cidadania insurgente, especialmente através de criação de comissão para apurar fato atípico, o que, na verdade, serve de mecanismo para incutir medo nos indivíduos ${ }^{199}$.

\footnotetext{
${ }^{198}$ Em 23 de novembro de 2016, solicitei ao Ministério Público do Rio de Janeiro que me fossem disponibilizadas para consulta as atas das reuniões da CEIV. Em 7 de dezembro, recebi a seguinte resposta: "Senhora Solicitante, em resposta à solicitação no 0161123 - 155634, informamos que a Comissão Especial de Investigação de Atos de Vandalismo (CEIV) foi instituída com o objetivo de facilitar o trabalho e a tomada de ações coordenadas entre o Ministério Público do Estado do Rio de Janeiro e as Polícias Civil e Militar do Estado do Rio de Janeiro, não havendo registros públicos de suas reuniões durante o lapso temporal de sua existência. Todavia, em anexo, seguem os atos normativos da CEIV. Equipe Sic / Ministério Público do Estado do Rio de Janeiro." (grifos meus)

Em 15 de maio, invocando a Lei de Acesso à Informação, escrevi para o Governo do Estado do Rio de Janeiro, fazendo a mesma solicitação. Recebi a seguinte resposta: "Prezada Raquel, Em cumprimento à Lei de Acesso à Informação, segue abaixo a resposta referente à solicitação, sob o número de protocolo 751: 'Meu nome é Raquel Dias e sou mestranda em Direito da PUC-Rio. Um dos meus objetos da minha pesquisa é a CEIV, criada por decreto do ex-Governador Sérgio Cabral (Decreto Estadual $\mathrm{n}^{\circ}$ 44.302/2013), em julho de 2013, com objetivo de prevenir e reprimir atos de vandalismo nas manifestações iniciadas em junho de 2013. Com isso, gostaria de indagar ao Governo do Estado se existem registros públicos a respeito das reuniões e deliberações da Comissão Especial de Investigação de Atos de Vandalismo em Manifestações Públicas (CEIV), cujo período de vigência corresponde aproximadamente a 19.07.2013 a 27.09.2013.': De acordo com o Decreto Estadual 44.305, que revogou o Decreto Estadual 44.302, ambos em anexo, a presidência da Comissão Especial de Investigação de Atos de Vandalismo em Manifestações Públicas (CEIV) compete ao Ministério Público do Estado do Rio de Janeiro (MPRJ). Desta forma, orientamos que entre em contato com o órgão por meio do link < http://www.mprj.mp.br/transparencia/servicos-de-informacao-ao-cidadao $>$ para realizar o seu pedido de acesso à informação. Atenciosamente, Governo do Estado do Rio de Janeiro." Em novo envio ao MPRJ, destacando que o pedido era feito com base na Lei de Acesso à Informação, recebi, em 19 de maio de 2017, a seguinte resposta: "Prezada Senhora Raquel Costa Dias, Em resposta ao seu requerimento de n. 20170519 - 155103, cujo objeto é obtenção de informações a respeito da Comissão Especial de Investigação de Atos de Vandalismo (CEIV), reportamo-nos à resposta dada ao requerimento de Vossa Senhoria, de n. ${ }^{\circ} 20161123$ - 155634, de 23/11/2016, a qual já comunicava não haver registros públicos das referidas reuniões. Em anexo, reencaminhamos a resposta dada ao requerimento 20161123 - 155634. Equipe Sic / Ministério Público do Estado do Rio de Janeiro."

${ }^{199}$ Promotor de Justiça Tiago Joffily em palestra ministrada na $42^{\mathrm{a}}$ reunião do Fórum Permanente de Direitos Humanos da Escola da Magistratura do Estado do Rio de Janeiro (EMERJ): "Direito à manifestação, democracia e garantias constitucionais", em 26 de setembro de 2013. EMERJ, Serviço de Áudio e Vídeo. "É impossível ou muito difícil de afirmar de que maneira se iniciam os tais atos de violência que ocorrem em muitas das manifestações".
} 
Nada mais didático neste sentido do que o decreto de revogação da CEIV, publicado em 27 de setembro de 2013, no sentido de que a Comissão "atingiu as suas finalidades":

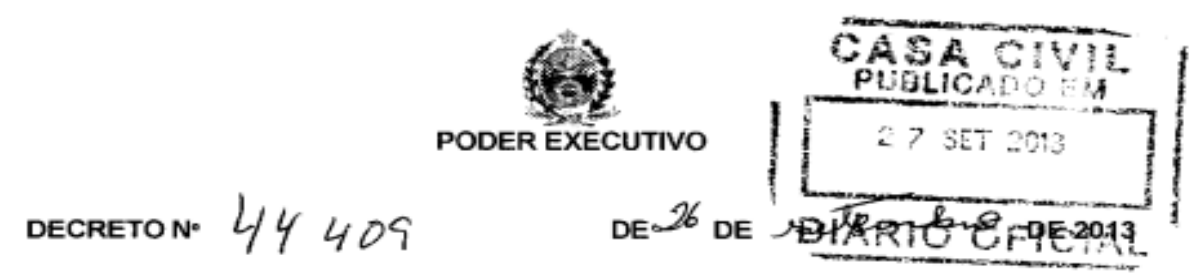

REVOGA O DECRETO $n^{\circ} 44.305$, DE 24 DE JULHO DE 2013.

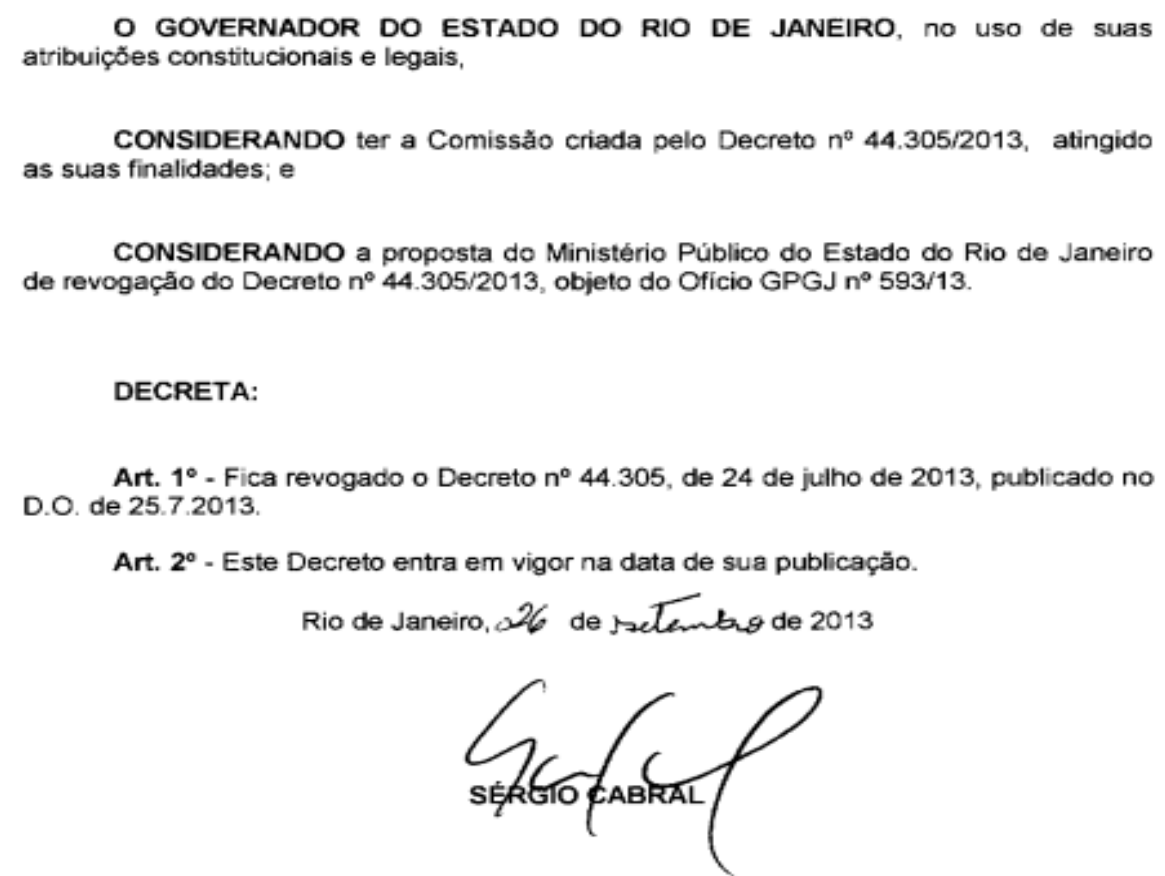

Imagem 1. Decreto de Revogação da CEIV

Mas a instrumentalização de leis para conter a cidadania insurgente não foi prática apenas do Executivo e Legislativo fluminenses. Também no Congresso Nacional, com a sanção da Presidenta Dilma Rousseff, foi aprovada lei que afetou diretamente os manifestantes no Rio de Janeiro. 


\section{2 .2}

\section{A Lei de Organizações Criminosas - Lei 12.850/2013}

A Lei de Organizações Criminosas ${ }^{200}$ é oriunda do Projeto de Lei do Senado (PLS) $n^{\circ}$ 150/2006, apresentado pela ex-senadora Serys Slhessarenko (então do PT-MT). Passados três anos da sua propositura, em 2009, foi aprovado pelo Senado Federal e enviado à Câmara dos Deputados (PL 6578/2009), onde foi levou mais três anos para ser aprovado, o que ocorreu no fim de 2012, tendo voltado ao Senado para aprovação na casa iniciadora.

O projeto, que vinha tramitando há seis anos e que havia retornado ao Senado havia sete meses, subitamente teve o seu trâmite acelerado após as manifestações de junho de 2013. Foi aprovado no dia 11 de julho e, em 2 de agosto de 2013, a presidente Dilma sancionava a Lei $\mathrm{n}^{\circ} 12.850$, cuja publicação ocorreu em 5 de agosto de 2013, com prazo de vacância fixado em 45 dias.

A Lei 12.850/13 passou, então, a definir organização criminosa e dispor sobre a investigação criminal, os meios de obtenção da prova como delação premiada e infiltração de agente, infrações penais correlatas e o procedimento criminal. Parece-nos que, inicialmente, sua aplicação teria - ou deveria ter - como foco o crime organizado, por meio das sanções àqueles que integram organizações sofisticadas para o cometimento de ilícitos.

Na prática, entretanto, notou-se a real intenção de mais uma legislação incriminadora: centenas de manifestantes foram indiciados - e até mesmo denunciados - pelo crime de organização criminosa após o crescimento das manifestações nas ruas, que tiveram o seu ápice em 2013.

Para compreender a relação entre a referida Lei e as manifestações populares, analisamos a sua tramitação desde o começo, em $2006^{201}$. O que, a

\footnotetext{
${ }^{200}$ BRASIL. Lei $\mathrm{n}^{\circ}$ 12.850, de 2 de agosto de 2013. Diário Oficial da República Federativa do Brasil, Brasília, DF, 3 ago. 2013. Disponível em: $<$ https://www.planalto.gov.br/ccivil_03/_ato2011-2014/2013/lei/112850.htm>. Acesso em: 12 set. 2016.

${ }^{201}$ O PLS foi apresentado ao Senado em 23 de maio de 2006, sendo enviado no dia seguinte à Comissão de Constituição e Justiça (CCJ), para que fossem recebidas eventuais emendas. Após o decurso do prazo para tanto, que se deu 7 dias após seu envio à CCJ, foi designado relator para apresentar parecer sobre o PLS apenas em 3 de julho de 2006, o Senador Demóstenes Torres. Em 13 de março do ano seguinte, o Senador Aloízio Mercadante tornou-se o novo relator do projeto em comento, sendo seu primeiro parecer, favorável ao projeto, aprovado na CCJ no dia 21
} 
princípio, parece ter sido um procedimento normal para a criação de uma lei ordinária, a partir de uma análise mais aprofundada dos andamentos do Projeto de Lei no Congresso Nacional, principalmente no seu momento final, quando o trâmite ganhou status de "urgência" na Câmara dos Deputados ${ }^{202}$, podemos considerar uma "coincidência" no fato de tal agilidade ter sido influenciado por interesses do poder constituído.

Em 4 de dezembro de 2012, foi feito o requerimento para que o feito tramitasse sob o regime de urgência, o que, dentre outras consequências, determina que o projeto seja colocado em pauta na sessão deliberativa

do mesmo mês. Após o oferecimento de algumas emendas, o parecer final foi aprovado em 7 de novembro daquele ano, aguardando dia para inclusão em pauta destinada à deliberação do Plenário a partir de 21 de novembro de 2007. Seu encaminhamento ao Plenário, entretanto, demorou mais de um ano, ocorrendo apenas em 25 de março de 2009. Antes que se deliberasse, entretanto, foram oferecidas mais algumas emendas, além da realização de uma audiência pública para debate, da qual participaram líderes de órgãos policiais, representantes da Ordem dos Advogados do Brasil e do Ministério Público, além do então presidente do STF, Ministro Gilmar Mendes.

Participaram de pelo menos uma das duas etapas da audiência pública os senhores: Fernando Barros e Silva de Souza, Procurador-Geral da República, Sandro Torres Avelar, Presidente da Associação Nacional dos Delegados de Polícia Federal (ADPF); Carlos Eduardo Benito Jorge, Presidente da Associação dos Delegados de Polícia do Brasil (ADEPOL do Brasil); José Carlos Cosenzo, Presidente da Associação Nacional dos Membros do Ministério Público (CONAMP); Wladimir Sérgio Reale, Advogado criminalista; Leonardo Azeredo Bandarra, Procurador-Geral de Justiça do Distrito Federal e Territórios e Presidente do Conselho Nacional de Procuradores-Gerais do Ministério Público dos Estados e da União - CNPG; Abizair Antônio Paniago, Presidente do Conselho Nacional de Chefes de Polícia Civil (CONCPC), e Superintendente da Polícia Civil do Estado de Tocantins; Percílio de Sousa Lima Neto, Vice-Presidente da Comissão de Direitos Humanos do Conselho Federal da Ordem dos Advogados do Brasil. representante do Presidente do Conselho Federal da OAB, Cezar Britto; e Salise Monteiro Sanchotene, Presidenta do Grupo Jurídico da ENCLA - Estratégia Nacional de Combate à Corrupção e Lavagem de Dinheiro. Somente em 6 de novembro de 2019 o feito foi novamente incluído em pauta, ou seja, quase dois anos depois da aprovação do parecer final, restando o substitutivo aprovado em 2 de dezembro, e remetido à Câmara dos Deputados para que atuasse como Casa Revisora ainda naquele mês.

${ }^{202} \mathrm{O}$ projeto foi então recebido na Câmara, passando a tramitar em regime de prioridade sob a identificação de PL n ${ }^{\circ}$ 6578/2009, não mais de PLS 150. A Mesa Diretora, em 17 de dezembro de 2009, determinou que as Comissões de Segurança Pública e Combate ao Crime Organizado (CSPCCO), a Comissão de Constituição, Justiça e Cidadania (CCJC) e a Comissão de Finanças e Tributação apresentassem pareceres sobre a matéria. Quanto a esta última, em momento posterior, foi dispensada a apresentação de parecer.

O primeiro parecer favorável ao projeto da CSPCCO foi apresentado somente em dezembro do ano seguinte, pelo relator João Campos. Após a apresentação de emendas e votos, o parecer final foi aprovado em agosto de 2011, sendo o projeto remetido à Coordenação de Comissões Permanentes, e, em sequência, à CCJC. Após a designação do Deputado Vieira da Cunha como relator do PL na CCJC, foi requerida Audiência Pública para debate da questão em 20 de outubro de 2011, a qual nunca chegou a acontecer. O PL, então, ficou estagnado até junho de 2012, quando começou a tramitar de forma consideravelmente mais rápida em comparação aos andamentos prévios.

Após a apresentação do primeiro parecer favorável, em 14 de junho de 2012, em 5 de setembro do mesmo ano foi requerido dia para inclusão em pauta. O parecer final pela aprovação do substitutivo foi apresentado no dia 30 do mês seguinte. 
imediatamente posterior à aprovação do requerimento de urgência, ainda que seja no mesmo dia ${ }^{203}$.

No dia seguinte, a proposta foi votada em turno único, sendo o substitutivo aprovado pela Câmara dos Deputados e já remetido ao Senado Federal sete dias depois. Para efeitos de comparação, enquanto o PLS 150/2006 aguardou por mais de 2 (dois) anos para deliberação, na Câmara dos Deputados o feito foi deliberado apenas três meses depois do seu requerimento, em virtude de um pedido de urgência para a sua tramitação.

Imediatamente após a entrada em vigor da Lei de Organizações Criminosas, o Estado policial o transformou em mais um meio (instrumentalizado) de repressão às manifestações populares. Dos diversos levantes populares realizados no ano de 2013, aquele ocorrido no dia 15 de outubro, Dia do Professor, destacou-se pela quantidade de pessoas - muitos estudantes e professores - presas, detidas ou simplesmente encaminhadas às Delegacias para "averiguação", chegando a 200 a quantidade de manifestantes presos ou detidos ${ }^{204}$.

\footnotetext{
${ }^{203}$ Sobre os regimes de tramitação na Câmara dos Deputados: "É o tipo de encaminhamento das proposições, determinado pelo tempo que tramitam nas diversas comissões. Elas podem ser urgentes, de tramitação com prioridade e de tramitação ordinária. Para tramitar em regime de prioridade, a proposição deve ser de iniciativa do Executivo, do Judiciário, do Ministério Público, da Mesa, de comissão permanente ou especial, do Senado ou dos cidadãos. Ainda tramitam nesse regime os projetos de lei complementar que regulamentam dispositivos constitucionais, de lei com prazo determinado, de regulamentação de eleições e de alteração do Regimento Interno. O regime de urgência dispensa algumas formalidades regimentais. Para tramitar neste regime, a proposição deve tratar de matéria que envolva a defesa da sociedade democrática e das liberdades fundamentais; tratar-se de providência para atender a calamidade pública; de Declaração de Guerra, Estado de Defesa, Estado de Sítio ou Intervenção Federal nos estados; acordos internacionais e fixação dos efetivos das Forças Armadas, entre outros casos. Uma proposição também pode tramitar com urgência, quando houver apresentação de requerimento nesse sentido. Caso a urgência seja aprovada, a proposição será colocada na Ordem do Dia da sessão deliberativa seguinte, mesmo que seja no mesmo dia. Outro regime de tramitação é o de urgência urgentíssima. Para isso, deve ser apresentado um requerimento assinado pela maioria absoluta de deputados ou líderes que representem esse número (257). O requerimento precisa ser aprovado pela maioria absoluta dos votos. Se aprovada, a proposição é incluída na Ordem do Dia da mesma sessão." Ver mais em: <http://www2.camara.leg.br/comunicacao/assessoria-de-imprensa/regime-detramitacao $>$. Acesso em: 24 mai. 2017.

204 "Segundo informações da Polícia Civil, no protesto realizado em apoio aos professores, no dia 15 de outubro, cerca de 190 pessoas foram conduzidas à força até as delegacias, tendo ocorrido 64 casos de prisão provisória em decorrência de supostos flagrantes." Prisões arbitrárias em manifestações são denunciadas à OEA. Memorial dos Direitos Humanos, 28 out. 2013. Disponível em: $\quad<$ http://memorialdh.sites.ufsc.br/prisoes-arbitrarias-manifestacoes-sao-denunciadas-oea/>. Acesso em: 22 mai. 2017.

"Os números são diferentes dos divulgados mais cedo pela Polícia Militar. De acordo com a PM, 182 pessoas foram encaminhadas para sete delegacias da cidade. A OAB, por sua vez, diz que foram 208 detidos, levados para dez delegacias". Polícia Civil: 70 são autuados por organização criminosa. $O$ Globo, São Paulo, 17 out. 2013. Disponível em:
} 
Nesta data, mais uma vez a chefia da Polícia Civil do Rio de Janeiro determinou a distribuição dos manifestantes presos às mais diversas delegacias da cidade, unidades policiais que jamais atenderiam ocorrências das circunscrições do centro da cidade do Rio de Janeiro, especialmente porque eram muito distantes desta localidade, com claro intuito de atrapalhar a atuação dos advogados voluntários, de diversas redes e coletivos. Além das já conhecidas unidades de polícia, os dois maiores grupos de manifestantes presos foram levados ao Engenho Novo $\left(25^{\mathrm{a}} \mathrm{DP}\right)$ e à Ilha do Governador (37 DP). Às demais delegacias foram levados os conduzidos "para averiguação" ou por terem cometido, em tese, crimes de menor potencial ofensivo.

A manifestação do dia 15 de outubro de 2013 foi, então, como as outras, marcada por prisões arbitrárias e aleatórias, porém com o uso da Lei de Organizações Criminosas como um instrumento repressor oportunamente novo, do qual a política criminal do poder constituído enfim pôde lançar mão. A Lei deu causa, de forma genérica e ilegal, à prisão de dezenas de jovens por formação de organização criminosa, embora muitos nunca tenham se visto antes de serem presos.

Neste mesmo dia, um professor de outro estado que, ao desembarcar no Aeroporto Santos Dumont e aderir ao movimento por solidariedade a sua classe, foi conduzido à $12^{\mathrm{a}} \mathrm{DP}$ sob a acusação de ter jogado pedra na PM. Lavrado o Termo Circunstanciado, foi solto, atordoado e agradecido ${ }^{205}$.

Naquela mesma delegacia, na madrugada do dia 16 de outubro, Sol e Victor $^{206}$ foram presos "em flagrante" por provocarem incêndio em cabine policial, o que nunca cometeram. Victor fora inicialmente levado ao presídio Patrícia Acioli ${ }^{207}$. Sol foi visitada por outros colegas no presídio feminino em

\footnotetext{
$<$ https://oglobo.globo.com/rio/policia-civil-70-sao-autuados-por-organizacao-criminosa10389531\#ixzz4huOcLtIa>. Acesso em: 24 mai. 2017.

${ }^{205}$ Os advogados do Grupo Habeas Corpus faziam o atendimento emergencial e orientavam os assistidos a procurarem a Defensoria Pública ou outros advogados (muitos, inclusive, igualmente voluntários), já que não tinham braços para dar continuidade na assistência jurídica na fase processual. Com isso, os papeis relativos aos atendimentos emergenciais eram entregues aos próprios atendidos, para que facilitasse a autuação do próximo colega, já que muitas vezes o acesso aos procedimentos em sede policial era praticamente impossível. No caso do professor em referência, como não foi possível localizá-lo para solicitar-lhe autorização para identificá-lo neste trabalho, por questões de ética profissional, a sua identidade será mantida em sigilo.

${ }^{206}$ Victor Gonçalves Ribeiro de Souza e Daniela Soledad dos Santos Barbosa.

${ }^{207}$ Esta unidade prisional foi construída sob um mangue na região de São Gonçalo/RJ e, por conta disso, os manifestantes presos em outubro de 2013 sofreram com centenas de picadas de
} 
Bangu. As duas prisões foram relaxadas somente no dia 25 de outubro. Entretanto, o poder constituído não contava com o trabalho de diversos fotógrafos amadores, cujos registros sustentaram suas absolvições tempos depois.

Vimos que, não obstante os autoritários e inquisitoriais meios de repressão instrumentalizados pelo poder constituído contra os levantes populares já estivessem sendo praticados há tempos, a Lei de Crimes Organizados foi, ao nosso ver, a mais importante ferramenta repressiva à época. Isto porque, com base em acusações oriundas de suas normas, bastava a vontade do policial para que manifestantes fossem presos em flagrante, diminuindo as conduções por crimes de menor potencial ofensivo (que continuavam a existir), mas aumentando significativamente a quantidade de prisões. Exemplo disso é que, dos 64 presos durante o ato de 15 de outubro, 27 pessoas foram indiciadas por, pelo menos, um dos crimes tipificados na Lei $12.850 / 13$. Foi o primeiro grande ato popular a ser reprimido por meio desta lei, o que provocou intensos debates e diversas manifestações sobre a sua aplicação nesse contexto ${ }^{208}$.

Do equivocado rótulo de "vândalos" - dado aos manifestantes pelo instinto punitivo do Estado - à qualificação como integrantes de uma organização criminosa, todas essas ações foram por nós consideradas como meios de criar o inimigo a ser combatido. Para exemplificar a visão do poder constituído à época dos fatos, vejamos, respectivamente, as declarações de Martha Rocha, então chefe da Polícia Civil do Rio de Janeiro, e José Mariano Beltrame, Secretário de Segurança Pública neste período, no dia seguinte a manifestação do Dia dos Professores, sobre a aplicação Lei de Organizações Criminosas nas manifestações:

Nós olhamos para este grupo como um bando, na forma como o termo é descrito no Código Penal. Nossa decisão passa pelo crivo do Poder Judiciário. (...) Se tem um movimento caótico, no qual queimaram uma viatura e um micro-ônibus (da polícia) do estado, o que nós temos de fazer é punir essas pessoas. Esse é o

mosquitos. Esta foi uma verdadeira tortura que os impedia de dormir e, além disso, eles foram proIbidos de receber os repelentes que os advogados levaram.

${ }^{208}$ TORRES, Lívia. Ato no Rio tem 64 presos, diz polícia; 27 são autuados por crime organizado. O Globo, São Paulo, 16 out. 2013. Disponível em: <http://g1.globo.com/rio-dejaneiro/noticia/2013/10/ato-no-rio-tem-64-presos-27-deles-autuados-em-lei-de-crimeorganizado.html>. Acesso em: 21 mai. 2017. 
esforço técnico que a polícia vem fazendo no sentido de buscar o enquadramento que o Poder Judiciário aceite. ${ }^{209}$

O "esforço técnico", citado por Beltrame, era a instrumentalização da repressão através da Lei 12.850/13, usada pela polícia e ratificada nas acusações do Ministério Público e decisões do Poder Judiciário, como meio de jogar os manifestantes nas masmorras que são os presídios no Rio de Janeiro. Há de se questionar, entretanto, se era essa a intenção do legislador ao dar disciplina especial ao crime organizado. Há de se pensar a ratio desta lei e, principalmente, se a conduta praticada pelos manifestantes subsume-se aos tipos penais nela estabelecidos. Não temos dúvidas de que a proposição da lei pelo Senado, em 2006, não objetivava prender manifestantes que sequer se conheciam.

Em outra entrevista, três dias após as prisões de 15 de outubro, Beltrame trata a necessidade de autorizações por parte do Poder Judiciário para tomarem medidas que viabilizassem a identificação dos "vândalos" como "questões do judiciário" (onde Beltrame disse "questões", inevitavelmente lemos "problemas"):

Estamos atrás por uma série de questões como falta de equipamentos. Vejo que a gente tem dificuldades para identificar algumas pessoas. Ainda tem questões do Judiciário e, não poderia ser diferente, porque qualquer ação precisa ser autorizada", disse. Beltrame diz não saber se a nova lei de organização criminosa, aplicada pelos delegados do Rio, é a ideal. "Esse é o nosso desafio. É algo muito novo. Quem sabe a saída não seja agravar o crime de dano ou criar o tipo penal de vandalismo", diz. ${ }^{210}$

Trata-se, em verdade, de um questionamento da aplicação do poder punitivo de forma autoritária, porquanto distorcida, transgredindo os limites estabelecidos pelo legislador para instrumentalizar a Lei em favorecimento e satisfação de seus anseios políticos e econômicos: a repressão dos movimentos populares e o esvaziamento das ruas, causando a impressão de que é perigoso se manifestar para fazer cessar as ameaças ao poder constituído, tão somente preocupado em manter o status quo.

\footnotetext{
${ }^{209}$ Polícia investiga importação de vândalos aos protestos. Revista Veja, São Paulo, 16 out. 2013. Disponível em: <http://veja.abril.com.br/brasil/policia-investiga-importacao-de-vandalos-aosprotestos/>. Acesso em: 21 mai. 2017.

210 'Setor de inteligência das polícias está lento', afirma Beltrame. Folha de São Paulo, São Paulo, 18 out. 2013. Disponível em: <http://wwwl.folha.uol.com.br/cotidiano/2013/10/1358434inteligencia-policial-esta-lenta-afirma-beltrame.shtml>. Acesso em: 21 mai. 2017.
} 
Desnecessária e inócua aos levantes de 2013, a Lei foi introduzida no ordenamento jurídico brasileiro em adequação ao Protocolo de Palermo ${ }^{211}$, o qual o Brasil aderiu em 2004, com vistas a reprimir crimes transnacionais, especialmente grupos mafiosos. As condutas residuais e eventualmente típicas dos manifestantes que, ao nosso ver, eram legítimas, já possuem tipificação própria em nosso ordenamento jurídico e não se confundem, nem dependem de enquadramento na Lei 12.850/13.

A aplicação da Lei de Organizações Criminosas não repercute somente na acusação de crimes mais graves aos manifestantes, cujas penas são de prisão, mas também na possibilidade de meios de obtenção de prova mais invasivos e sofisticados ${ }^{212}$, pensados pelo legislador justamente para que se possa combater o verdadeiro crime organizado, o que não deveria ser o caso de jovens manifestando democraticamente.

A Lei, em tese, foi pensada para coibir e reprimir aqueles que se organizam de forma sofisticada para o cometimento de crimes, formando uma verdadeira organização criminosa, e, para tanto, traz seu conceito logo no parágrafo primeiro do artigo $1^{0213}$, estabelecendo alguns requisitos (elementos objetivos e subjetivos) para a caracterização de uma organização criminosa: número mínimo de participantes, organização interna ordenada mediante

\footnotetext{
${ }^{211}$ É uma convenção internacional da ONU, em que Estados visam a combater em conjunto grupos criminosos que atuam ao mesmo tempo em vários países. São terroristas, por exemplo, mas a lei se aplica mais em casos de lavagem de dinheiro, tráfico de pessoas.

212 "Art. $3^{3}$ : Em qualquer fase da persecução penal, serão permitidos, sem prejuízo de outros já previstos em lei, os seguintes meios de obtenção da prova: I - colaboração premiada; II - captação ambiental de sinais eletromagnéticos, ópticos ou acústicos; III - ação controlada; IV - acesso a registros de ligações telefônicas e telemáticas, a dados cadastrais constantes de bancos de dados públicos ou privados e a informações eleitorais ou comerciais; V - interceptação de comunicações telefônicas e telemáticas, nos termos da legislação específica; VI - afastamento dos sigilos financeiro, bancário e fiscal, nos termos da legislação específica; VII - infiltração, por policiais, em atividade de investigação, na forma do art. 11; VIII - cooperação entre instituições e órgãos federais, distritais, estaduais e municipais na busca de provas e informações de interesse da investigação ou da instrução criminal.

$\S 1^{\circ}$ Havendo necessidade justificada de manter sigilo sobre a capacidade investigatória, poderá ser dispensada licitação para contratação de serviços técnicos especializados, aquisição ou locação de equipamentos destinados à polícia judiciária para o rastreamento e obtenção de provas previstas nos incisos II e V."

$\S 2^{\mathrm{o}}$ No caso do $\S 1^{\circ}$, fica dispensada a publicação de que trata o parágrafo único do art. 61 da Lei $\mathrm{n}^{\circ}$ 8.666, de 21 de junho de 1993, devendo ser comunicado o órgão de controle interno da realização da contratação.

213 "Considera-se organização criminosa a associação de 4 (quatro) ou mais pessoas estruturalmente ordenada e caracterizada pela divisão de tarefas, ainda que informalmente, com objetivo de obter, direta ou indiretamente, vantagem de qualquer natureza, mediante a prática de infrações penais cujas penas máximas sejam superiores a 4 (quatro) anos, ou que sejam de caráter transnacional."
} 
divisão de tarefas, com o fim de obter vantagens por meio do cometimento de dois ou mais ilícitos que possuam pena máxima superior a 4 anos ou que sejam de caráter transnacional.

Os participantes dos movimentos de 2013 não se enquadrariam nestes requisitos nem de longe, menos ainda na hipótese de um estado de flagrância de organização criminosa. Não nos restam dúvidas que sua utilização é política e autoritária. A organização dos manifestantes se deu de forma descentralizada, sem que houvesse qualquer hierarquia ou divisão de tarefas interna. Trata-se da multidão, da multiplicidade de indivíduos que foram às ruas defender suas pautas de forma horizontal e, não obstante alguns indivíduos tenham eventualmente praticado condutas tipificadas durante os atos populares, não se pode imputá-los o crime de participação em uma organização criminosa.

Excluída a possibilidade de estarem organizados e ordenados estruturalmente, é inaplicável, portanto, esta Lei aos manifestantes. Há, ainda, outro requisito que igualmente não se aplica ao caso dos manifestantes: a do dolo específico para obtenção de vantagens ${ }^{214}$. Os professores, alunos, jovens e populares que estiveram na manifestação do dia 15 de outubro não estavam lá com o fim de obter alguma vantagem, mas sim com a finalidade de pautar suas reivindicações por, dentre outras coisas, salários atrasados e melhores condições de trabalho e de ensino. Enquadrá-los no tipo penal que exige uma vantagem nunca auferida é ação autoritária e fascista de um poder constituído pronto para suprimir qualquer resistência ao status $q u o^{215}$. Seu uso vem acontecendo de forma política, como meio de repressão do Estado em desfavor da multidão que busca as ruas para realizar a democracia absoluta.

Daquela data em diante, as manifestações passaram a ser dispersadas ainda mais brutalmente, muitas vezes antes de começar. Violência física e

\footnotetext{
${ }^{214}$ Como anteriormente mencionado, a maior parte dos manifestantes eram enquadrados em crimes de menor e médio potencial ofensivo, o que igualmente não se adequam ao tipo das organizações criminosas, que exige a união para a prática de crimes mais graves.

215 "As bandeiras levantadas pelos movimentos sociais, seja quando trazem à tona pautas locais, seja quando representem genuínas contestações anticapitalistas, não podem ser consideradas -vantagem de qualquer naturezall, porque não há vantagem alguma. Trata-se tão somente de exercer o direito fundamental à liberdade de expressão, liberdade de reunião e livre manifestação do pensamento. Lutar, por melhores condições de existência, definitivamente, não é crime. A tentativa de enquadrá-las como vantagens que caracterizem uma organização criminosa corresponde, em última instância, à criminalização da ação política, típica de Estados fascistas e autoritários." MELCHIOR \& SOARES E SOUZA, 2015.
} 
psicológica, muitas bombas e correria: essa era a regra. Inclusive, até 14 de julho de $2014^{216}$, menos detenções e prisões foram realizadas neste período, pois a violência do poder constituído era tanta que encontrava pouca ou quase nenhuma resistência. Depois de 15 de outubro, todos tinham medo do poder constituído soberano e autoritário, que seguia abraçado à Lei de Organizações Criminosas.

E é assim até hoje no Rio de Janeiro ${ }^{217}$, as manifestações da coletividade pautada em melhorias de qualidade de vida, de serviços básicos essenciais, de atraso de salários do funcionalismo público estadual, dentre outras causas, foram e ainda são violentamente reprimidas desde o seu início. Mas, como o objetivo deste trabalho é demonstrar a repressão criminal do devir-multidão de 2013, devemos voltar ao contexto, agora referindo-nos às prisões ocorridas em 11 de julho de 2014, quando a grande mídia cravou sua posição contrária às ruas no imaginário de seus telespectadores.

\subsection{3.}

\section{O "Processo dos 23"}

Conforme visto anteriormente, a ação repressiva estatal às manifestações populares se deu de forma progressiva, culminando no "Processo dos 23 " que decretou a prisão temporária de 23 manifestantes dentro dos autos do inquérito $n^{\circ}$ 218-01646/2013 (27 a Vara Criminal do Rio de Janeiro). O processo foi aberto às vésperas da estreia da Copa do Mundo no Brasil e os 23 denunciados foram detidos no dia 18 de julho de 2014 sob o pretexto de impedir atos de violência que

\footnotetext{
${ }^{216}$ Data da prisão preventiva dos 23. Entre outubro de 2013 e julho de 2014, ocorreu, em fevereiro, "a trágica morte do cinegrafista Santiago Andrade, atingido acidentalmente por um rojão disparado por dois manifestantes, esvaziaria as ruas de vez, dados o mal estar gerado pelo incidente entre os próprios ativistas, a imediata prisão dos dois ativistas implicados, e a estrondosa reação corporativa dos jornalistas e meios de comunicação." PILATTI, 2016b, p. 22.

${ }^{217}$ Alguns relatos de abusos por parte da Polícia Militar do Rio de Janeiro no dia 28 de abril, dia em que foi convocada "greve geral" no Brasil. Muitos manifestantes no centro do Rio foram agredidos gratuitamente pela Polícia Militar do Rio de Janeiro, havendo vídeos que demonstram o bombardeio de gás lacrimogêneo a esmo, sem qualquer critério, tão somente porque haviam pessoas aglomeradas no intuito de manifestarem. Ver mais em: Manifestantes relatam momentos de terror durante ação da polícia no centro do Rio. Extra, Rio de Janeiro, 28 abr. 2017. Disponível em: $<$ https://extra.globo.com/noticias/rio/manifestantes-relatam-momentos-de-terror-durante-acaoda-policia-no-centro-do-rio-
}

21275045.html?utm_source=Facebook\&utm_medium=Social\&utm_campaign=Extra $>$. Acesso em: 24 mai. 2017. 
estariam sendo arquitetados para o dia 20, no contexto das manifestações de encerramento da Copa.

À época, diversas instituições como a OAB-RJ ${ }^{218}$, a Anistia Internacional $^{219}$ e a Associação Juízes para a Democracia ${ }^{220}$ condenaram por meio de atos, notas públicas e pareceres técnicos a repressão estatal que antecedeu à prática dos próprios atos que poderiam originar responsabilidade por parte dos manifestantes, as ameaças e as prisões de advogados junto a seus clientes e a detenção ilegal de pessoas para que elas pudessem delatar os manifestantes que já vinham sendo monitorados desde 2013. O fator que mais assombrou parte da opinião pública e, sobretudo, a comunidade jurídica, foi a flagrante ilegalidade das prisões, uma vez que os manifestantes foram detidos e responsabilizados por atos que não haviam cometido ainda. Em entrevista a um veículo de mídia alternativa $^{221}$, o juiz João Batista Damasceno, inclusive, chegou a comparar a ação da polícia fluminense com a atividade de videntes, que supostamente teriam o poder de antever fatos futuros no presente.

Outro fator amplamente criticado pela comunidade jurídica foi a anormalidade em relação à tramitação do processo e à apreciação do material probatório. A fim de esclarecer tais pontos de crítica e de sublinhar aspectos relevantes dos mecanismos legais e extralegais de repressão criminal utilizados para abafar as manifestações populares, a seguir, serão analisados de forma mais aprofundada os pormenores desse marco simbolizado pelo Processo dos 23 .

A ação penal $n^{o}$ 00229018-26.2013.8.19.0001, que possui, ao todo, mais de 8 mil folhas e que está dividida em 11 volumes, foi originada de dois inquéritos policiais distintos, o IP $n^{\circ} 218-00944 / 2013$ e o IP $n^{\circ} 218-01646 / 2013$, ambos iniciados pela Delegacia de Repressão aos Crimes de Informática (DRCI). A fim

\footnotetext{
${ }^{218}$ CONSTANCIO, Thaise. OAB-RJ recorre à OEA contra prisão de manifestantes. Estadão, São Paulo, 22 jul. 2014. Disponível em: < http://www.estadao.com.br/noticias/geral,oab-rj-recorre-aoea-contra-prisao-de-manifestantes,1532476>. Acesso em: 22 mai. 2017.

${ }^{219}$ OAB-RJ repudia prisões de ativistas pela Polícia do Rio de Janeiro. Revista Consultor Jurídico, São Paulo, 13 jul. 2014. Disponível em: <http://www.conjur.com.br/2014-jul-13/oab-rj-repudiaprisoes-ativistas-policia-rio-janeiro>. Acesso em: 22 mai. 2017.

${ }^{220}$ MACEDO, Fausto. Juízes para a Democracia condenam 'repressão às mobilizações populares'. Estadão, São Paulo, 15 jul. 2014. Disponível em: <http://politica.estadao.com.br/blogs/faustomacedo/juizes-para-a-democracia-condenam-repressao-as-mobilizacoes-populares/>. Acesso em: 22 mai. 2017.

${ }^{221}$ LEMES, Conceição. Damasceno: No Rio, polícia "Mãe Dinah" antevê crime; equivale a Estado de Sítio. Viomundo, São Paulo, 13 jul. 2014. Disponível em: <http://www.viomundo.com.br/denuncias/juiz-damasceno.html>. Acesso em: 22 mai. 2017.
} 
de delimitar o escopo da presente pesquisa, serão analisados os pontos mais cruciais do Inquérito Policial $\mathrm{n}^{\mathrm{o}}$ 218-01646/2013, que foi instaurado com a finalidade de resguardar o sigilo da segunda parte das investigações iniciadas nos autos do IP $n^{\circ} 218-00944 / 2013$ e que possui a carga probatória relativa ao crime que originou o Processo dos 23, de associação criminosa.

No apenso do Inquérito Policial $n^{\circ}$ 218-01646/2013 constam peças sigilosas que foram desentranhadas dos autos principais e uma ampla gama de documentos que comprovam o monitoramento intenso dos acusados desde 2013. O primeiro documento do apenso, uma representação do Ministério Público datada de 6 de novembro de 2013, explicita a finalidade de investigar o denominado "núcleo articulador", que seria "responsável pela criação do vínculo entre os movimentos legítimos e os ilegítimos de forma a permitir o êxito desses últimos".

O inquérito teria como objetivo "identificar os demais integrantes", "esclarecer a existência de associação permanente e organizada com a finalidade de infiltrar criminosos nas manifestações legítimas" e "reforçar os indícios apontados no inquérito de forma a permitir ao Ministério Público o oferecimento de eventual denúncia",222.

$\mathrm{Na}$ representação que justifica a necessidade de interceptação e quebra do sigilo das comunicações telefônicas e telemáticas, bem como de busca e apreensão, fica mais claro ainda como a reação institucional em relação às manifestações espelha o olhar ditatorial, herdado das décadas de Ditadura Militar, que é lançado aos movimentos sociais. A caracterização do que será entendido como black blocs para efeitos de investigação permite vislumbrar melhor tal fato:

Os integrantes dos 'black blocs' são contra a lei e a ordem, considerados instrumentos da burguesia, e impõem suas vontades sem qualquer consideração pelos interesses coletivos, paralisando ruas e avenidas, quebrando vidraças de lojas e de agências bancárias e incendiando carros e ônibus, tudo em nome de suas utopias totalitárias.

Eles se aproveitam de problemas reais para criar o caos e impasses insolúveis se infiltrando nos protestos para causar baderna. Os integrantes dos 'black blocs' distribuíram cartilhas com táticas de guerra adotando como estratégias assaltos,

\footnotetext{
${ }^{222}$ BRASIL. $27^{\text {a }}$ Vara Criminal do Rio de Janeiro. Ação Penal no 00229018-26.2013.8.19.0001.
} Juiz: Flávio Itabaiana de Oliveira Nicolau. Rio de Janeiro, 6 de novembro de 2013, fl. 51. 
emboscadas, execuções e uso de coquetéis molotov impondo o revide não pacífico às forças policiais.

Black Bloc constitui uma tática de ação política que se impõe por meio do vandalismo e da violência deliberada com o propósito imediato de chamar a atenção e de incutir terror na sociedade e nos agentes políticos. ${ }^{223}$

A criminalização coletiva de organizações sociais e a depreciação prévia de atores sociais se dá também sempre que há algum trecho qualificando um suposto integrante da quadrilha de black blocs ${ }^{224}$. A todo momento, ao longo do inquérito, a participação dos acusados em movimentos políticos - seja sindicatos, organizações ou associações - é sublinhada, como se ali estivesse algum tipo de indício do caráter violento e agitador do investigado. $\mathrm{O}$ engajamento em movimentos sociais é visto enquanto subversividade, esta, que deve ser eliminada e excluída da vida pública.

Outra estratégia bastante utilizada no inquérito com o intuito de descreditar movimentos oriundos da sociedade civil é a de ligá-los a supostos esquemas de financiamento de manifestantes para o cometimento de atividades ilícitas. A forma escolhida para comprovar essa ligação, no entanto, foi baseada em pressuposições sem base probatória e em matérias da grande mídia, conforme podemos ver abaixo.

Os líderes das manifestações não exercem atividade remunerada, porém, possuem computadores, tablets e celulares sofisticados para militarem virtualmente, o que fortalece a suspeita de que são financiados para praticarem atos de vandalismo.

(...)

A Revista Época publicou uma matéria em novembro de 2013 sobre a existência de um centro de treinamento para manifestantes profissionais onde são doutrinados a atuar em causas legítimas, mas de forma violenta, recebendo benefícios de diversas ONGs. ${ }^{225}$

Até mesmo o envolvimento com profissionais da advocacia popular é motivo de questionamento no inquérito, a fim de sugestionar a existência de um

\footnotetext{
${ }^{223}$ BRASIL. $27^{\mathrm{a}}$ Vara Criminal do Rio de Janeiro. Ação Penal no 00229018-26.2013.8.19.0001. Juiz: Flávio Itabaiana de Oliveira Nicolau. Rio de Janeiro, 6 de novembro de 2013. Apenso, fls. 666-667 (grifos meus).

${ }^{224}$ Remetemos à pagina 44 (item 3.1.), nota $\mathrm{n}^{\circ} 156$.

${ }^{225}$ BRASIL. 27 $7^{\mathrm{a}}$ Vara Criminal do Rio de Janeiro. Ação Penal no 00229018-26.2013.8.19.0001. Juiz: Flávio Itabaiana de Oliveira Nicolau. Rio de Janeiro, 6 de novembro de 2013. Apenso, fls. $122-123$.
} 
suposto financiamento por parte da rede de Defensores Independentes de Direitos Humanos (IDDH) ${ }^{226}$.

Outro ponto saliente que se faz presente é que, no decurso do inquérito, os investigados mudam de papel em relação aos atos investigados e à existência de quadro probatório capaz de ligá-los a uma suposta rede voltada para o cometimento de atos violentos. Um exemplo é o de uma das investigadas que não consta na denúncia por "insuficiência de provas",227, mas que na fundamentação para a quebra do sigilo dos dados cadastrais, telefônicos, bancários e físcais, datada de 31 de março de 2014, cerca de quatro meses antes da decretação das prisões, consta como "uma das líderes no movimento Ocupa Cabral"228. Tal oscilação demonstra que as autoridades, na verdade, buscavam a partir do inquérito construir artificialmente redes de influência e de articulação que não se verificavam no plano fático.

Outra flagrante arbitrariedade que pode ser constatada foi a forma como foram conduzidas as buscas e apreensões. Ao longo do inquérito, pode-se verificar que inúmeras buscas e apreensões foram feitas sem mandado judicial e sem que houvesse uma fundada suspeita da prática de um crime ou da existência de material ilícito. Nos relatórios de busca e apreensão, é possível perceber, ainda, que as apreensões obedeceram a um olhar discriminatório em relação a movimentos sociais, às manifestações, a símbolos de ideologias contrahegemônicas e a itens pessoais que foram interpretados enquanto suspeitos sem a existência de uma razão subjacente.

Foram apreendidos desde itens como documentos pessoais, computadores, celulares, pen drives e outras mídias, a itens como uma bandeira do Brasil com o símbolo da anarquia ${ }^{229}$ e outra sem nenhum símbolo ${ }^{230}$, uma máscara com adesivo

\footnotetext{
226 "Baiano e Sininho foram acusados por alguns manifestantes de receberem dinheiro (...), a última foi questionada pelo seu envolvimento com o Deputado Marcelo Freixo, sempre acionado por ela nos casos de prisão de manifestantes para obter assistência jurídica gratuita dos advogados

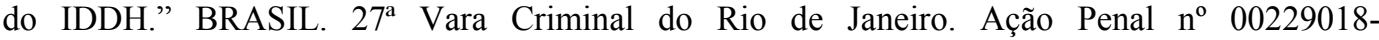
26.2013.8.19.0001. Juiz: Flávio Itabaiana de Oliveira Nicolau. Rio de Janeiro, 6 de novembro de 2013. Apenso, fl. 123.

${ }^{227}$ BRASIL. $27^{\mathrm{a}}$ Vara Criminal do Rio de Janeiro. Ação Penal no 00229018-26.2013.8.19.0001. Juiz: Flávio Itabaiana de Oliveira Nicolau. Rio de Janeiro, 6 de novembro de 2013, fl. 2070.

${ }^{228}$ BRASIL. $27^{\mathrm{a}}$ Vara Criminal do Rio de Janeiro. Ação Penal no 00229018-26.2013.8.19.0001. Juiz: Flávio Itabaiana de Oliveira Nicolau. Rio de Janeiro, 6 de novembro de 2013. Apenso, fl. 112.

${ }^{229}$ Ibid., fl. 1422.

${ }^{230}$ Ibid., fl. 744.
} 
de apoio ao Sindicato Estadual dos Profissionais da Educação do Estado do Rio de Janeiro (SEPE) ${ }^{231}$, uma placa vermelha com o dizer "Ocupa Carnaval",232, panfletos sem cunho político ${ }^{233}$ e bens de uso pessoal como aliança, Rio Card, cartão de plano de saúde, revistas de história, mala de viagem, bandana da banda Nirvana e uma camiseta de caveira ${ }^{234}$.

Inclusive, em um dos documentos de informação sobre a investigação, de 17 de julho, consta uma leitura tal dos objetos apreendidos que uma das investigadas, porque foi encontrada sob a posse de folhas com assinaturas em apoio aos movimentos de ocupações, recortes de notícias de jornal, cópias de notas públicas e de panfletos a favor das manifestações e de fotos com outros investigados, acabou sendo considerada como tendo "um grande engajamento nas principais manifestações que ocorrem no país" ${ }^{235}$.

Com a análise do inquérito, outro fator a ser salientado, é o uso de termos como "meliantes”, “terror”, “causas legítimas e ilegítimas”, “utopias totalitárias”, dentre outros ${ }^{236}$. Somado a isso, está o fato de os manifestantes serem qualificados como "ativistas" e participantes de movimentos políticos como forma de utilizar tais elementos como indícios de que estes eram violentos e de que se colocariam acima da "Lei e da Ordem" - termo também bastante mencionado ao longo do inquérito - "com a justificativa de que defendem direitos, colocando em perigo a Paz e a Segurança Pública"237.

Conforme vimos no capítulo anterior, uma das funções não declaradas do sistema penal ainda é o de sustentar a hegemonia de um determinado segmento social sobre outros, pretensamente em prol da manutenção da ordem e da paz sociais, bem como das leis e demais instituições. Contudo, o controle penal visa

\footnotetext{
${ }^{231}$ BRASIL. 27 ${ }^{\mathrm{a}}$ Vara Criminal do Rio de Janeiro. Ação Penal no 00229018-26.2013.8.19.0001. Juiz: Flávio Itabaiana de Oliveira Nicolau. Rio de Janeiro, 6 de novembro de 2013. Apenso, fl. 1752.

232 Ibid., fl. 733.

${ }^{233}$ Ibid., fl. 735.

${ }^{234}$ Ibid., fls. 739-748.

${ }^{235}$ Ibid., fl. 1753.

${ }^{236}$ Para mais exemplos de trechos em que há o uso de uma linguagem tendenciosa e que constrói a narrativa de terrorismo, ver mais em: BRASIL. $27^{\mathrm{a}}$ Vara Criminal do Rio de Janeiro. Ação Penal $\mathrm{n}^{\mathrm{o}}$ 00229018-26.2013.8.19.0001. Juiz: Flávio Itabaiana de Oliveira Nicolau. Rio de Janeiro, 6 de novembro de 2013. Apenso, fls. 372-405.

${ }^{237}$ BRASIL. 27 ${ }^{\mathrm{a}}$ Vara Criminal do Rio de Janeiro. Ação Penal no 00229018-26.2013.8.19.0001. Juiz: Flávio Itabaiana de Oliveira Nicolau. Rio de Janeiro, 13 de julho de 2013, fl. 1913. A mesma frase se encontra em outros documentos.
} 
fundamentalmente, a partir da escolha de um inimigo passível de servir como justificativa para a repressão, a sustentação do status quo. A seletividade da escolha desse inimigo pode ser explicitada no inquérito por meio da observação mais detida em relação à forma como a linguagem é trabalhada para convencer de que a "guerra seria justa".

Assim como a linguagem, toda a narrativa é construída de forma a justificar arbitrariedades e um uso político do processo penal. Um dos ápices dessa narrativa foi a infiltração ilegal de um agente da Força Nacional, Maurício Alves da Silva, cujo testemunho virou uma das principais provas de acusação. Alegando ser um estudante de pós-graduação de Brasília, Maurício fez contato com um grupo de advogados e de midiativistas e passou a participar dos chats entre eles, dos bares que eram marcados e, inclusive, passou a frequentar a casa de alguns $^{238}$.

Contudo, em 9 de julho de 2014, Maurício se apresentou ao DRCI e assumiu estar em um papel duplo, isto é, como agente secreto desde 3 de março, no contexto dos protestos cariocas. Segundo ele, "desde o dia em que pisou no Rio estava 'atuando como observador' para coletar dados para atuação da Força Nacional na Copa" e com a missão de evitar que policiais fossem atacados por coquetéis molotov $^{239}$. Dentro das manifestações, seu papel era o de filmá-las em tempo real, transmitindo para os órgãos de inteligência.

No Termo de Declaração, Maurício consta como um cidadão comum, embora estivesse ali a serviço da instituição militar a que servia. Segundo testemunho dado nos dias 9 e 27 de março de 2015, já em sede judicial e na fase de instrução processual, ele assume que o seu comandante foi a pessoa que o ordenou a ir até a delegacia prestar o depoimento. No mesmo testemunho de 2015, confessou que outros policiais estavam agindo da mesma forma que ele e que "não sabe se havia autorização judicial específica para sua missão"240.

A admissão no processo de um agente infiltrado enquanto testemunha acusadora foi objeto de um habeas corpus, que pede a anulação das provas colhidas sem autorização judicial. $\mathrm{O}$ pedido, que foi negado em primeira e

\footnotetext{
${ }^{238}$ VIANA, 2017.

${ }^{239}$ BRASIL. 27 $7^{\mathrm{a}}$ Vara Criminal do Rio de Janeiro. Ação Penal no 00229018-26.2013.8.19.0001. Juiz: Flávio Itabaiana de Oliveira Nicolau. Rio de Janeiro, 9 de julho de 2014, fls. 1102-1103.

${ }^{240}$ VIANA, op. cit.
} 
segunda instâncias, se encontra desde setembro de 2015 pendente de julgamento pelo STJ.

\subsubsection{1.}

\section{A prisão temporária e a prisão preventiva dos 23}

A despeito de todas as arbitrariedades e da condução irregular do inquérito, no dia 9 de julho de 2014 foi apresentada pelo promotor Luís Otávio Figueira Lopes a representação pela decretação temporária de 28 supostos integrantes de uma "quadrilha armada" que estaria arquitetando a prática de atos de violência para os dias seguintes. Aos 28 indiciados foi imputada a prática do delito de associação criminosa, tipificado no artigo 288, parágrafo único do Código Penal ${ }^{241}$. Na palavra do próprio MP, a prisão seria justificada pelos seguintes motivos.

Da leitura dos autos verifica-se que há sérios indícios de que está sendo planejada a realização de atos de extrema violência para os próximos dias, a fim de aproveitar a visibilidade decorrente da cobertura da copa do mundo de futebol, sendo de todo necessária a atuação no sentido não só de impedir a consumação de tal objetivo como também de identificar os demais integrantes da associação. ${ }^{242}$

O que fica notório pela leitura do trecho é que a justificativa para as prisões foi feita baseada em "indícios" depreendidos dos autos (os quais não são descritos) de que atos futuros seriam cometidos. Prossegue, ainda, o Ministério Público, detalhando que a prisão teria o efeito "no sentido de neutralizar a ação" dos indiciados, pelos crimes que eles sequer haviam ainda cometido.

O mesmo parágrafo transcrito acima pode ser visto praticamente em sua íntegra como parte da decisão de 10 de julho de 2014 do juiz Flávio Itabaiana de

\footnotetext{
${ }^{241}$ Art. 288. Associarem-se 3 (três) ou mais pessoas, para o fïm específico de cometer crimes: Pena - reclusão, de 1 (um) a 3 (três) anos.

Parágrafo único. A pena aumenta-se até a metade se a associação é armada ou se houver a participação de criança ou adolescente.

Observamos que tal artigo do Código Penal foi alterado pela já analisada Lei $\mathrm{n}^{\circ} 12.850 / 2013$, que “define organização criminosa e dispõe sobre a investigação criminal, os meios de obtenção da prova, infrações penais correlatas e o procedimento criminal."

${ }^{242}$ BRASIL. 27 $7^{\mathrm{a}}$ Vara Criminal do Rio de Janeiro. Ação Penal nº 00229018-26.2013.8.19.0001. Juiz: Flávio Itabaiana de Oliveira Nicolau. Rio de Janeiro, 9 de julho de 2014, fls. 1097-1099.
} 
Oliveira Nicolau ${ }^{243}$. Contendo apenas uma página com considerações genéricas que remetem ao inquérito, sem esclarecer qual a fundamentação cabível, a decisão também frisa a necessidade de identificar os demais coautores para que um aprofundamento das investigações fosse realizado.

Tal ênfase nos dois documentos em relação à urgência de oitiva dos indiciados não deve se passar por irrelevante, tendo em vista que a justificativa de identificar os integrantes da organização serviu para forçar delações e infundir medo nos manifestantes a fim de coletar maiores informações. Conforme veremos mais a fundo no próximo tópico, conduções coercitivas foram realizadas para que os envolvidos testemunhassem e, inclusive, o direito de permanecer em silêncio destes foi violado.

Se na representação feita pelo Ministério Público, 28 manifestantes foram alvo do pedido de prisão, na denúncia oferecida em 18 de julho de $2014^{244}, 5$ deles não foram incluídos pelo MP por ausência de elementos seguros nos autos no sentido do cometimento de condutas criminosas. Ora, frente à inexistência de tais elementos passíveis de transformar participantes das manifestações populares em indiciados dentro de uma longa investigação, que já vinha se arrastando há mais de um ano, qual seria o real motivo para decretar a prisão temporária dos mesmos? Por que o mesmo promotor, Luís Otávio Figueira Lopes, mudou a sua ratio apenas 9 dias depois?

$\mathrm{Na}$ denúncia, o único trecho que busca justificar o porquê por detrás da inclusão de uma indiciada no rol do pedido de prisão temporária evidencia que, segundo os autos, a mesma não era partícipe de ato delituoso algum é o que se segue:

Quanto a [indiciada], é fato que esta participava ativamente das manifestações e de sua organização, inclusive dialogando com outros indiciados. Não há, todavia, elemento que permita ligá-la diretamente à prática dos atos descritos na denúncia, ao mesmo no estado que a investigação se encontra. ${ }^{245}$

Resta claro o desrespeito à ordem constitucional, uma vez que a única evidência que fez a indiciada pertencer ao rol de prisões temporárias decretadas,

\footnotetext{
${ }^{243}$ BRASIL. 27 $7^{\mathrm{a}}$ Vara Criminal do Rio de Janeiro. Ação Penal no 00229018-26.2013.8.19.0001. Juiz: Flávio Itabaiana de Oliveira Nicolau. Rio de Janeiro, 10 de julho de 2014, fls. 1119-1120.

${ }^{244}$ Ibid., fls. 2068-2073.

${ }^{245}$ Ibid., fl. 2070.
} 
foi o exercício de seu direito assegurado à liberdade de manifestação e de reunião. Outra garantia violada foi a da presunção de inocência e, a partir desse exemplo, cabe a reflexão sobre o motivo de apenas alguns manifestantes terem sido selecionados pelo Ministério Público em detrimento de tantos outros que estavam participando ou construindo coletivamente as manifestações.

É possível deduzir, portanto, que algumas das prisões decretadas tiveram o intuito de forçar algum tipo de testemunho e uma delação de outros possíveis envolvidos na pretensa associação criminosa. Assim, somadas às irregularidades do inquérito, a instrumentalização da prisão processual com a finalidade de obter confissões e como meio de constrangimento para gerar delações é outro fator que se integra ao quadro de flagrante ilegalidade.

Outro argumento contrário à decisão que decretou as prisões temporárias é o de que tal instrumento não seria cabível. Isto porque, dado que o seu objetivo é o de restringir a liberdade de um acusado para efetuar a produção probatória do crime que supostamente fora cometido por ele, no caso dos manifestantes que estavam sendo investigados e monitorados de forma incessante desde setembro de 2013 - o que se pode comprovar nas mais de 8 mil páginas da ação penal - não existia a necessidade de produzir mais provas de forma emergencial. Além disso, o fato delituoso nem ao mesmo havia sido cometido, tampouco se sabe se seria cometido algum ato ilícito. Nesse sentido, pode-se comprovar também que não estavam presentes os requisitos da custódia cautelar, quais sejam, o periculum in mora, ou o "perigo na demora", e o fumus boni iuris, ou a "fumaça do bom direito".

A decisão de prisão temporária viola, assim como a representação ministerial, não individualizam as condutas e nem contêm a devida explicitação dos fatos que deveriam legitimar a necessidade de prisão temporária, deixando claro que a custódia fora feita tomando por base eventos incertos e futuros.

Além de cercear a liberdade dos acusados sem fundamentação e violar os princípios da liberdade de expressão e da liberdade de reunião plasmados na Constituição, a decisão do juiz Flávio Itabaiana posiciona o Poder Judiciário enquanto o respaldo necessário para que as arbitrariedades cometidas pelas autoridades policiais ganhassem uma roupagem de legalidade. Ao invés de se posicionar enquanto garantidor de direitos, nesse caso, o Judiciário agiu de forma 
inquisitória e não seria forçoso afirmar que as prisões somente foram decretadas com o intuito de incutir medo e de frustrar a participação massiva de jovens nas manifestações da Copa do Mundo, que estavam sendo vistas no mundo inteiro.

Por fim, em relação à denúncia de 18 de julho opinando no sentido da decretação da prisão preventiva dos 23 indiciados, em momento algum da mesma o Ministério Público faz menção a provas concretas passíveis de comprovar a prática do delito de associação criminosa. Isto violaria o artigo 41 do Código de Processo Penal ${ }^{246}$, que descreve como requisito da denúncia a exposição do fato criminoso, uma vez que, a partir da leitura da denúncia, não é possível identificar quais as circunstâncias concretas do fato que constituiria o delito penal.

Frisa-se que, a todo o tempo, as justificativas giram em torno de provas cabais que estariam nos autos, mas sem mencionar exatamente quais seriam estas. Há, também constantemente, menção à manutenção à ordem pública, que seria perturbada no futuro, o que nos mostra que a responsabilidade por atos ainda não cometidos já recaíam, a priori, sobre os manifestantes:

Isto, pois, consoante se verifica dos autos, tratam-se de indivíduos com forte atuação na organização e prática dos atos de violência em manifestações populares, havendo nos autos indícios claros de que, em liberdade, voltarão à prática de atos de tal natureza. A custódia cautelar é, pois, necessária a assegurar a ordem pública. ${ }^{247}$

\subsubsection{2.}

\section{O "Processo dos 23" e os mecanismos extralegais de repressão estatal}

Além de o processo não tramitar normalmente desde 2013, por meio de entrevistas com advogados de defesa dos indiciados, é possível se aprofundar acerca dos artifícios utilizados pelas autoridades policiais e pela justiça para

\footnotetext{
${ }^{246}$ Art. 41. A denúncia ou queixa conterá a exposição do fato criminoso, com todas as suas circunstâncias, a qualificação do acusado ou esclarecimentos pelos quais se possa identificá-lo, a classificação do crime e, quando necessário, o rol das testemunhas.

${ }^{247}$ BRASIL. $27^{\mathrm{a}}$ Vara Criminal do Rio de Janeiro. Ação Penal no 00229018-26.2013.8.19.0001. Juiz: Flávio Itabaiana de Oliveira Nicolau. Rio de Janeiro, 10 de julho de 2014, fl. 2072.
} 
encobrir o processo e, também, evidenciar os mecanismos extralegais de repressão e as violações às prerrogativas profissionais dos advogados ${ }^{248}$.

Em entrevista, o advogado Marino D'icarahy Junior ${ }^{249}$ denuncia outros fatores que eivariam o processo de ilegalidade, como o fato de as interceptações telefônicas realizadas abarcarem também comunicações entre advogados de defesa e seus clientes. Um outro aspecto salientado por ele, é o de que o inquérito possui inúmeras menções a partidos políticos, políticos, instituições e governos, tendo um peso político que contaminaria o processo em sua origem. Somado a isso, corroborando com o que vimos na seção anterior, o processo seria fruto de delações duvidosas e de testemunhos contaminados. Sobre os testemunhos, ele acrescenta que o interrogatório não se destinava para a apuração de um fato específico, mas sim já seria pré-elaborado para buscar identificar a posteriori uma rede fabricada a priori pelos próprios inquisidores.

Outra violação narrada por Marino foi a de que o acesso ao inquérito fora negado a diversos advogados que atuavam em defesa dos ativistas indiciados. Em 13 de junho de 2014, ele conta que o acesso ao inquérito foi negado na delegacia e, depois, na própria Vara Criminal. Em um primeiro momento, ao questionar o delegado sobre o paradeiro do inquérito, ele lhe informou que estava em juízo, mas ao chegar na $27^{\mathrm{a}}$ Vara, ele recebeu a notícia de que o inquérito estava com o delegado desde o dia 5 de junho, indicando a má-fé do agente público.

Outro exemplo de embaraço que impedia o exercício de suas prerrogativas profissionais, foi o fato de que, ao buscar o processo no sistema eletrônico do Tribunal, ele constava como inexistente. A obstrução do processo era tamanha que este não chegava a tramitar no cartório da Vara e os funcionários deste setor eram instruídos a informar que não tinham qualquer conhecimento acerca do processo e

\footnotetext{
${ }^{248}$ A fim de justificar as violações às prerrogativas de advogados, o seguinte trecho da Representação Policial de 31 de março de 2014 narra: "Muitos advogados alegaram na imprensa que estavam sendo investigados por prestar assistência jurídica gratuita aos manifestantes violentos que são presos. Ocorre que apenas aqueles que permaneceram com os manifestantes, em tempo integral, nos protestos e movimentos de ocupação de atos violentos, sem recebimento de honorários, e os que convocaram os manifestantes para as ocupações demonstraram atitudes suspeitas e contrárias ao estabelecido no Código de Ética da OAB ao fomentarem práticas de crimes". Ver mais em: BRASIL. 27 $7^{\mathrm{a}}$ Vara Criminal do Rio de Janeiro. Ação Penal n ${ }^{\circ} 00229018$ 26.2013.8.19.0001. Juiz: Flávio Itabaiana de Oliveira Nicolau. Rio de Janeiro, 10 de julho de 2014. Apenso, fl. 381.

${ }^{249}$ D'ICARAHY, M. Entrevista exclusiva com Marino D'icarahy, advogado de Sininho e outros 11 presos políticos no Rio. Jornal A Nova Democracia, São Paulo, 29 ago. 2014. Disponível em: $<$ https://www.youtube.com/watch?v=atOGs9u4b5c $>$. Acesso em: 25 mai. 2017.
} 
que ele estava sendo processado "secretamente" junto ao juiz Flávio Itabaiana. Segundo Marino, nem mesmo ao desembargador Siro Darlan, da $7^{\text {a }}$ Câmara Criminal do Rio, que concedeu habeas-corpus aos manifestantes, foi permitido o acesso ao inquérito $^{250}$.

Tais situações expostas comprovam ainda mais a violação de garantias legais desde o nascedouro do procedimento instaurado contra os 23 ativistas políticos. Frisa-se ainda que, mesmo em sede de inquérito sigiloso, o acesso aos elementos de defesa não pode ser negado à defesa dos investigados, segundo dicção da Súmula 14 do Supremo Tribunal Federal ${ }^{251}$.

No entanto, ao advogado Mario Fabrizio Polinelli também foi obstruído o direito de vista dos autos. Em entrevista realizada no âmbito da presente pesquisa $^{252}$, Polinelli descreve uma situação idêntica à que ocorreu com Marino: chegando à delegacia, fora informado de que o processo se encontrava na $27^{\mathrm{a}}$ Vara. Contudo, no próprio Cartório constava um aviso afixado na porta explicando de antemão que o Processo $\mathrm{n}^{\mathrm{o}}$ 00229018-26.2013.8.19.0001 não tramitava por lá, mas que, ao invés disso, ia direto para o Gabinete do juiz. Ao questionar sobre o paradeiro do processo na Vara Criminal, foi informado que ele estava na delegacia, evidenciando, novamente, o ímpeto dos agentes da justiça de embaraçar a defesa processual dos indiciados.

Dessa forma, o processo foi tornado inacessível desde a sua origem e assim permanece até agora. Em sede da presente pesquisa, foi tentada, novamente, a obtenção de vistas no processo e, mesmo após retirado o sigilo da ação penal, o acesso foi negado sob a justificativa de que o processo estaria com o juiz de forma ininterrupta.

Afirma Polinelli que somente obteve acesso aos autos peticionando ao juiz Flávio Itabaiana, que deferiu. No entanto, mais uma ação fraudulenta foi efetivada: a DRCI só disponibilizou os autos ao advogado 24 horas após o recebimento do ofício e, nesse meio tempo, renumeraram o processo e retiraram

\footnotetext{
${ }^{250}$ CONSTANCIO, Thaise. OAB-RJ recorre à OEA contra prisão de manifestantes. Estadão, São Paulo, 22 jul. 2014. Disponível em: <http://www.estadao.com.br/noticias/geral,oab-rj-recorre-aoea-contra-prisao-de-manifestantes, 1532476>. Acesso em: 22 mai. 2017.

${ }^{251}$ Súmula 14, STF. É direito do defensor, no interesse do representado, ter acesso amplo aos elementos de prova que, já documentados em procedimento investigatório realizado por órgão com competência de polícia judiciária, digam respeito ao exercício do direito de defesa.

${ }^{252}$ A transcrição da entrevista se encontra no Anexo I do presente trabalho.
} 
materiais probatórios relevantes, criando a partir destes um apenso secreto. $\mathrm{O}$ advogado só teve acesso a esse apenso extra quando do recebimento da denúncia. Dessa forma, vê-se que a obstrução se deu a partir de diversas formas, culminando na alteração do próprio conteúdo processual passível de ser acessado pelos advogados de defesa.

Sobre o mérito da acusação sofrida por sua cliente, Polinelli narra que não existia nenhuma acusação específica e nenhuma prova que a incriminasse, já que ela apenas constava como participante das manifestações no inquérito. Inclusive, um mês depois, o Ministério Público não a denunciou exatamente por conta dessa ausência de fato concreto a ser imputado. A despeito disso, ela foi conduzida coercitivamente para a delegacia, embora não houvesse ordem judicial de condução coercitiva e embora ela não tenha sido intimada a depor. Ainda, sem que tenha sido lavrado auto de apreensão, sua cliente teve pertencentes apreendidos, tal como documentos pessoais, um ipad e pen drives, bens estes que nunca chegaram a ser devolvidos e que em nada tinham a ver com o processo.

Chegando à delegacia, a informaram que ela estava depondo na condição de testemunha - após ser conduzida ilegalmente e sofrer uma medida de busca e apreensão. Uma vez que ela se encontrava ali sem o prévio acesso aos autos, a indiciada expressamente anunciou que exerceria seu direito constitucional de permanecer em silêncio. Contudo, o que se sucedeu marca mais uma arbitrariedade, conforme se pode ver a partir deste trecho retirado do Termo de Declaração de 11 de junho de 2014: "que a declarante tomou ciência que figura como testemunha, portanto, não pode permanecer em silêncio conforme requerido por ela" ${ }^{253}$.

Não bastasse que a sua cliente tivesse tido o seu direito ao silêncio negado, Polinelli ainda acrescenta que, ao longo da oitiva, ela chegou a sofrer ameaça da delegada assistente Renata Araújo dos Santos de que "se não quisesse falar como testemunha, seria indiciada na hora e sua prisão seria pedida” ${ }^{, 254}$.

Em tom de conclusão, o que vemos em relação ao "Processo dos 23" é um procedimento eivado de ilegalidades como condução coercitiva sem mandato e

\footnotetext{
${ }^{253}$ BRASIL. 27 $7^{\mathrm{a}}$ Vara Criminal do Rio de Janeiro. Ação Penal no 00229018-26.2013.8.19.0001. Juiz: Flávio Itabaiana de Oliveira Nicolau. Rio de Janeiro, 11 de junho de 2014, fl. 663.

${ }^{254}$ Ibid., fl. 775 (grifos meus).
} 
busca e apreensão em relação a testemunhas, delações forçadas, testemunha infiltrada sem autorização judicial, denúncias e decisões sem fundamentação suficiente, obstrução de acesso aos autos do processo (mesmo para aqueles que estavam consignados nos autos), ameaças e outras violações às prerrogativas profissionais dos advogados, intercepções telefônicas ilegais, dentre outras arbitrariedades. No contexto da presente pesquisa, é importante perceber que:

O temor da renovação daquele ciclo de lutas desestruturantes e constituintes, em que a multidão jovem e pobre por um momento deixou de ter medo e passou a meter medo nos poderosos do Estado e do Capital, continua a inspirar e alimentar estratégias policiais, judiciais e legislativas de vigilância, controle e repressão. A necessidade de "uma nova política", com "mais participação da cidadania" é farisaicamente afirmada pelos mesmos que fazem tudo para manter a política corrompida de sempre, impermeável à participação autônoma da cidadania e dos movimentos sociais. 255

Por essa razão, tão importante quanto denunciar o controle e a repressão instrumentalizados contra os movimentos constituintes, é apontar o quão são prejudiciais para a real democracia - com participação e tomada de decisão pelo dissenso -, sugerindo, sem pretensão de esgotá-los, alguns caminhos para a sua implementação.

${ }^{255}$ PILATTI, 2016b, p. 29. 


\section{As Consequências para a Democracia}

A proposta desse capítulo é a de pensarmos quais as consequências que a forte repressão deixou à ação democrática, exercida pela multidão, buscando demonstrar o prejuízo causado à multidão insurgente, a qual não se beneficia da manutenção do status quo. Isso significa pensarmos que a instrumentalização do Estado para reprimir a multidão nas ruas deixou, sim, consequências na democracia brasileira. Isto, sobretudo porque, na nossa percepção, o pensamento autoritário e o modelo inquisitorial de processo penal que, materialmente, nunca nos deixaram, foram fortalecidos e até mesmo valorizados através das respostas desproporcionais dadas ao poder constituinte pelo poder constituído, causando um efeito intimidatório e dissuasivo nos sujeitos insurgentes.

Pensamos, contudo, ser improvável qualquer análise recente sobre quais são as consequências da repressão violenta e autoritária às jornadas de junho de 2013 em relação aos governos já instituídos, seja na esfera municipal, estadual ou federal. No momento atual, muitas seriam as perspectivas de análise, pois entendemos que, como anunciado nas ruas em 2013, existe uma grave crise nas instituições democráticas do país.

Por isso, não é possível, ainda, afirmar se a repressão autoritária das jornadas foi um catalisador da crise política atual, viabilizando a destituição de uma presidenta democraticamente eleita - por motivos, ao nosso ver, escusos, e em mais uma demonstração de desrespeito à vontade do povo (tendo sido muito desses desrespeitos, inclusive, respaldados pela mesma presidenta) - ou se passaríamos por esse momento de qualquer forma, independentemente dos levantes de 2013. Também não nos é possível pensar a respeito destas consequências porque, no exato momento em que este 
trabalho é concluído, estamos passando por uma nova crise política, a segunda em um ano, agora protagonizada pelo governo do presidente Michel Temer.

Já no estado do Rio de Janeiro, desde junho de 2016, foi decretado estado de calamidade pública em razão da sua grave crise financeira. Até o momento atual, a Assembleia Legislativa do Rio de Janeiro está decidindo acerca da sua prorrogação até o ano de $2018^{256}$, a pedido do poder executivo estadual. O decreto aprovado desde junho de 2016 autoriza a implementação de medidas austeras contra os servidores e contra as instituições do estado. Aqui, pelo menos, podemos afirmar que a gestão fraudulenta das contas do Estado, anunciada já antes de 2013, mas sobretudo nas ruas em 2013, especialmente em razão dos grandes eventos sediados no Rio e de subsídios estatais ao empresariado fluminense (estes, um tanto questionáveis), certamente estão por detrás desta situação calamitosa.

Para nós, o contexto político atual permite afirmarmos que o ano de 2013 ainda não acabou, mas não é possível, contudo, afirmar se e quando ele acabará em relação às consequências para os governos instituídos e as suas práticas.

A análise das consequências das jornadas de 2013 que ainda estão em ebulição não é, portanto, o objetivo deste último capítulo, mas a análise das consequências à democracia a partir de uma abordagem crítica ${ }^{257}$ do processo

\footnotetext{
${ }^{256}$ Segundo notícia do site da Alerj, publicada em 30 de maio de 2017: “A Assembleia Legislativa do Estado do Rio de Janeiro (Alerj) retoma, nesta quarta-feira (31/05), a votação do projeto de lei $2.627 / 17$, do Executivo, que prorroga o prazo de calamidade pública financeira do estado para o fim de 2018. Atualmente o prazo da calamidade vai até o fim de 2017 , conforme reconheceu a Lei 7.483/16. O texto-base do projeto foi aprovado na última terça-feira, dia 23, com 37 votos favoráveis a 26 dos deputados. De um total de 12 emendas destacadas, cinco foram votadas - duas aprovadas e três, rejeitadas. Sete emendas ainda precisam ser votadas.Com o reconhecimento do estado de calamidade, o Governo do Estado não precisa atender, temporariamente, aos limites de endividamento e de gastos com pessoal impostos pela Lei de Responsabilidade Fiscal (LRF).O texto-base aprovado, acatou emendas que priorizam, durante a vigência do estado de calamidade, a alocação de recursos do estado para as áreas de Saúde, Educação, Assistência Social e Ciência e Tecnologia terão prioridade na alocação de recursos, bem como o pagamento de servidores ativos, inativos e pensionistas. Também foi acordado entre os parlamentares que o Governo envie à Comissão de Orçamento da Casa, em até 30 dias após a lei entrar em vigor, um plano detalhado das medidas que pretende adotar para enfrentar a calamidade e também o relatório com os recursos que compõem a Receita Corrente Líquida (RCL). Outra alteração: a calamidade só poderá ser regulamentada pelo governador. Isto quer dizer que nenhum secretário do Executivo poderá regulamentar medidas utilizando a lei da calamidade." Disponível em:

$<$ http://www.alerj.rj.gov.br/Visualizar/Noticia/40575>. Acesso em: 31 mai. 2017.

257 "É preciso tomar o seu termo em todo o seu sentido: o da possibilidade de fazer aparecer o 'invisível'. Expliquemos esta formulação algo exotérica. Aquilo que é próprio de um pensamento abstracto consiste precisamente em poder evocar 'coisas' ou realidades na sua própria ausência. A
} 
penal nos interessa. Sobre este aspecto e o processo penal, postula Rubens

Casara que este:

Integra o conteúdo normativo do sistema penal, pertence ao plano do dever-ser, e está sujeito às oscilações provenientes das políticas criminais e das ideologias que o direcionam e influenciam. Assim, em dados contextos, as normas processuais podem servir de instrumento à redução do poder penal; em outros, atender à demanda por maior repressão, oriunda dos movimentos lei e ordem, apoiados por massiva veiculação da mídia. ${ }^{258}$

Neste contexto, o autor afirma - e nos é impossível discordar - que a insistência no "mito do processo penal" para uma pretendida pacificação social leva o Estado a aumentar o seu poder punitivo.

“A desconexão entre o dever ser e o ser só é possível e aceita em função de fatores externos (manutenção do status quo) e internos (manutenção, ainda que vã, do equilíbrio), em uma retroalimentação do sistema processual em vigor" ${ }^{259}$. Neste trecho, Jacinto Nelson de Miranda Coutinho destaca que para sair do "mal-estar do lugar comum" é preciso dar conta de "novas práticas democráticas" e, para tanto, é essencial a "assunção de uma postura ideológica" voltada à "emancipação do nosso povo"260.

\footnotetext{
abstração intelectual permite-me falar de mesa ou de cavalo, mesmo que não tenha uma mesa ou um cavalo sob os olhos no momento em que falo deles.

Esta faculdade, que parece evidente de tal modo nos é habitual, é afinal, o que constitui o essencial do pensamento abstracto. Mas o pensamento crítico é mais do que o pensamento abstracto: é preciso 'acrescentar-lhe' a dialéctica. Que quer isto dizer? O pensamento dialéctico parte da experiência de que o mundo é complexo: o real não mantém as condições da sua existência senão numa luta, quer ela seja consciente, quer inconsciente. A realidade que me surge num dado momento não é, pois, senão um momento, uma fase da sua realização: esta é, de facto, um processo constante. (...) Assim funciona o que eu chamo de pensamento crítico: ele merece este qualificativo neste sentido em que, suscitando o que não é visível, para explicar o visível, ele se recusa a crer e a dizer que a realidade se limita ao visível. Ele sabe que a realidade está em movimento, quer dizer, que qualquer coisa para ser apreendida e analisada tem de o ser no seu movimento interno; não se pode, pois, abusivamente reduzir o real a uma das suas manifestações, a uma das suas fases. (...) A teoria crítica nas ciências sociais traz uma reflexão de um género completamente diferente: ela reflecte, ao mesmo tempo, sobre as condições da sua existência, sobre a sua situação no seio da vida social. Funciona, pois, não só por si mesma, mas definindo as suas relações com o contexto em que surge. (...) Reflectindo sobre as condições e os efeitos da sua existência na vida social, a teoria reencontra a sua ligação com a prática, quer dizer, com o mundo social existente." MIAILLE, 1979, p. 18-19.

${ }^{258}$ CASARA, 2015, p. 198.

${ }^{259}$ COUTINHO, 1998, p. 15.

${ }^{260}$ Ibid., p. 4.
} 


\section{1.}

\section{Os Modelos Processuais: inquisitorial e democrático}

Com o objetivo de compreendermos o porquê de as repressões às jornadas de 2013 representarem um reforço ao pensamento inquisitorial, é importante esclarecer do que se trata tal pensamento e a sua origem. Portanto, explicamos que o pensamento inquisitorial que temos visto ser mantido refere-se ao enraizamento, em instituições democráticas, de práticas oriundas de um sistema processual inquisitivo, de bases autoritárias.

Admitimos que existem diversas concepções a respeito do conceito de sistema como estrutura processual que aqui não serão enfrentadas. Utilizamos a compreensão de sistema usada por Coutinho que, reconhecendo ser uma visão sucinta ${ }^{261}$, explica sistema como "um conjunto de temas jurídicos que, colocados em relação por um princípio unificador, formam um todo orgânico que se destina a um fim",262.

O princípio unificador é o que orquestra determinado sistema para o fim a que se destina e, tratando-se de sistemas processuais penais, tais princípios seriam: o princípio inquisitivo, que sustenta o sistema processual penal inquisitivo; e o princípio dispositivo (acusatório ${ }^{263}$ ), que sustenta o sistema processual penal acusatório ${ }^{264}$. Coutinho ressalva que os sistemas puros classicamente pensados não existem, são tipos históricos.

Na contemporaneidade, são todos sistemas mistos que não possuem um princípio unificador próprio, podendo ser essencialmente inquisitório, com características secundárias provenientes do sistema acusatório; ou

\footnotetext{
${ }^{261}$ Geraldo Prado acrescenta à ideia de sistema anotada por Carmen Lúcia Antunes Rocha, aduzindo que "um sistema não é um conjunto solto e desarticulado de normas e instituições, (...) mas sim uma realidade medida exatamente em virtude da coerência interna destas mesmas normas e instituições - acrescentaria princípios e sujeitos, que agem no interior do sistema de determinada maneira -, muito embora, hoje se saiba, que os sistemas não têm pretensão de absoluta harmonia e completude, o que explica eventuais antimonias e lacunas." PRADO, 2005, p. 54. Para um estudo mais aprofundado do tema, vide: CANARIS, Claus Wilhelm. Pensamento sistemático e conceito de sistema na ciência do direito. Tradução: A. Menezes Cordeiro. Lisboa: Gulbenkian, 1989.

${ }^{262}$ COUTINHO, 1998, p. 16.

${ }^{263}$ Concordamos com Geraldo Prado que entende que, "por princípio dispositivo, há de se entender aquele que permita dispor sobre o objeto do processo em tramitação, não sendo caracteristicamente acusatório ou inquisitório", razão pela qual optamos pelo uso da expressão princípio acusatório. PRADO, op. cit., p. 114.

${ }^{264}$ COUTINHO, 2001a, p. 17
} 
essencialmente acusatório, com características secundárias provenientes do sistema inquisitivo ${ }^{265}$.

Sem pretensão de adentrar em um estudo completo a respeito dos sistemas acusatório e inquisitório ${ }^{266}$, seus históricos e os princípios que os orientam, o que demandaria um trabalho específico e tempo destinado apenas para esse fim, utilizaremos aqui as anotações que, ao nosso ver, são mais relevantes para o presente trabalho, feitas pelos autores Jacinto Nelson de Miranda Coutinho ${ }^{267}$ e Geraldo Prado ${ }^{268}$.

Considerando que os sistemas inquisitivo e acusatório são antagônicos, falaremos, principalmente, das características do sistema inquisitivo, para que possamos anotar quais delas podem ser identificadas na repressão do poder constituído à multidão insurgente de junho de 2013.

Explicado qual o sentido de sistema aqui considerado, vimos que cada sistema processual penal é regido por um princípio unificador (inquisitório ou acusatório), e que no direito processual penal contemporâneo não existem sistemas puros, mas aqueles essencialmente inquisitórios ou essencialmente acusatórios, na medida em que ambos apresentam características do outro sistema. Isso implica igualmente em dizer que o sistema misto não possui um princípio unificador próprio (inexistindo um terceiro princípio unificador) porque, na verdade, apresenta características dos dois princípios com prevalências de características de um ou de outro, sendo esta prevalência que informa se um sistema processual privilegia práticas democráticas ou autoritárias.

As características dos dois sistemas são antagônicas e, como Jacinto nos ensina, o principal critério de identificação do princípio unificador é o da gestão da prova e a forma como ela é realizada ${ }^{269}$, nos interessando, primeiramente, dar destaque a algumas características da atividade probatória $^{270}$ no sistema inquisitório. Para Jacinto, esse critério é o principal,

\footnotetext{
${ }^{265}$ COUTINHO, 2001a, p. 18.

266 Para um estudo completo sobre o histórico dos princípios e suas nuances, recomendamos: PRADO, 2005, cap. 3, p. 61-166.

${ }^{267}$ COUTINHO, op. cit., p. 3-55. e COUTINHO, 2009, p. 253-262.

${ }^{268}$ PRADO, op. cit.

269 "É a gestão da prova e a forma como ela é realizada que identifica o princípio unificador". COUTINHO, 2009, p. 254.

270 "A atividade probatória não se limita a um debate no processo, com introdução de provas, a não ser que entendamos que a produção de provas é sempre produção de provas direcionada à
} 
uma vez que outros elementos que diferenciam os sistemas podem ser emprestados de um para o outro sistema, de modo que os considera elementos secundários $^{271}$.

Ou seja, a diferença fundamental é a relativa à concentração de poder na instrução probatória: no sistema inquisitório, o julgador recolhe e produz a prova, deixando ao acusado o papel de objeto da investigação, durante a qual muitas vezes é mantido preso cautelarmente, uma vez que é colocado "à disposição da acusação enquanto verdadeiro objeto e meio de prova. De certa forma, desaparece o cidadão; ou pode desaparecer."272. Para compreendermos a razão da sua permanência em sistemas contemporâneos que se dizem democráticos, necessário falarmos brevemente ${ }^{273}$ da origem do sistema inquisitivo.

Em síntese, esse sistema surgiu através da Igreja Católica com uma finalidade específica: conter o crescimento de relações comerciais e de trabalho que paulatinamente surgiam independentes do poder feudal, que tinha como a sua maior aliada a Igreja. Era, então, necessário defenderem-se do que se chamou de "doutrinas heréticas" que, de forma sucinta, podemos dizer que correspondiam ao "novo" que se coloca como "inimigo mortal das velhas práticas, das verdades consolidadas, do poder constituído" 274 .

O campo da "repressão canônica [iniciou-se] com equiparação das 'heresias' aos crimes de lesa-majestade", cabendo ao inquisidor julgar e acusar em um processo onde o acusado é apenas um "objeto de verificação" ${ }^{275}$. Nesta lógica, tem sentido a estrutura do sistema inquisitório colocar o juiz como superior, já que inexistentes as figuras de partes processuais, cabendo ao juiz o impulso do processo: para produzir provas e para decidir. Sem o contraditório, o juiz, que é o "senhor da prova", vai busca-la de acordo com "a visão que tem (ou faz) do fato" ${ }^{276}$. Assim, "a lógica dedutiva, que deixa ao inquisidor a escolha

determinação da existência e da vinculação subjetiva de um fato típico, ilícito e culpável, ou seja, de uma infração penal.” PRADO, 2005, p. 131.

${ }^{271}$ COUTINHO, 2009, p. 255.

272 Ibid.

${ }^{273}$ Conforme informado anteriormente, para uma análise histórica mais aprofundada, ver mais nas obras de PRADO, 2005, p. 61-166 e COUTINHO, 2001a, p. 18-31.

${ }^{274}$ COUTINHO, 2001a, p. 21.

275 Ibid., p. 23.

${ }^{276}$ Coutinho destaca que a ausência de partes é uma característica do sistema puro hoje não mais existente, daí porque qualifica essa característica como um elemento distintivo secundário do sistema inquisitorial. Ibid., p. 23-24. 
da premissa maior, razão pela qual pode decidir antes e, depois, buscar, quiçá obsessivamente, a prova necessária para justificar a decisão"277.

Ao mesmo tempo em que o juiz parte de premissas falsas para construir uma verdade, o crime passou a ser sinônimo de pecado, a partir do que a confissão seria o caminho para absolvição (Jacinto refere-se à concepção canônica de punir para absolver) e, seguindo essa lógica inquisitiva da busca da verdade, ninguém melhor do que o acusado para dizê-la. A junção destes fatores levou o sistema inquisitório, através do senhor da prova, isto é, o juiz, a utilizar-se de um instrumento capaz de alcançar aquela que foi denominada de "a rainha das provas", a confissão.

Sabemos, enfim, que tal instrumento é a tortura, a respeito da qual entendemos que, aqui, não cabem muitas explicações: é repugnante, especialmente porque "os tormentos não constituem um meio para descobrir a verdade, e sim um meio que leva o homem a se acusar de um crime, tenha-o ou não cometido" 278 .

Reconhecemos que na prática do direito processual penal brasileiro porque na forma é vedada pela Constituição (art. $5^{\circ}$, XLIII) - a tortura ainda é permitida e, pior, tolerada pelo poder constituído ${ }^{279}$. Inclusive não

\footnotetext{
${ }^{277}$ COUTINHO, 2001a, p. 25. "Franco Cordero explica que o chamado 'primado da hipótese sobre os fatos' revela-se como a situação, típica do sistema processual inquisitório, na qual são considerados e relevados apenas os significantes confirmadores da acusação, desprezando os demais. Nesses casos, forma-se um 'quadro mental paranoico' em que praticamente não há espaço para a defesa e o contraditório pouco influi.". MARRAFON, Marco Aurélio. Quadro mental paranoico não pode imperar na solução de casos jurídicos. São Paulo, Revista Consultor Jurídico, 14 jul. 2014. Disponível em: <http://www.conjur.com.br/2014-jul-14/constituicao-poder-quadromental-paranoico-nao-imperar>. Acesso em: 30 mai. 2017.

${ }^{278}$ VERRI apud COUTINHO, op. cit., p. 29.

279 Remetemos ao Relatório do Mecanismo Estadual de Prevenção e Combate à Tortura da Assembleia Legislativa do Estado do Rio de Janeiro (MEPCT/RJ): "A fragilidade da execução de políticas públicas que visa à garantia de direito potencializa um controle social punitivo institucionalizado (Zaffaroni e Pierangeli, 2011), não à toa o sistema prisional fluminense precisou lidar com a superlotação e suas conseqüências sobre as vidas daqueles que estão privados de liberdade. Entendemos que o sistema prisional é uma das engrenagens de um sistema penal que tem em sua base o sistema judiciário, que personifica algo como um desejo de vingança da sociedade como resposta a violência, sem que se faça uma reflexão sobre as raízes, as causas e mesmo os elementos produtores do medo. Contudo, ousamos dizer que a situação encontrada nas visitas realizadas pelo MEPCT/RJ atualiza a afirmação de Foucault 'nenhum de nós está livre da prisão. Hoje menos que nunca' (2006, pg. 2). O trabalho do MEPCT/RJ segue levando em consideração a Tortura em seu conceito mais amplo, no qual é possível afirmar que as condições desumanas encontradas nos presídios, tais como: superlotação; ausência de trabalho e escola; alimentação precária; falta de acesso à produtos de higiene pessoal; ausência de medicamentos; além de relatos de maus tratos, são o retrato de uma cultura que falsamente se diz ressocializar, mas que na verdade, produz tortura cotidianamente. Buscando debater com a sociedade não só a superlotação nos presídios, mas também o encarceramento em massa, o tema central do ano de 2016 foi a prisão provisória. Demonstramos as diversas causas do encarceramento desenfreado,
} 
desconsideramos o uso de mecanismos legais como instrumentos de tortura.

\author{
Referimo-nos, por exemplo, a mecanismos traumáticos como prisões \\ preventivas e conduções coercitivas $^{280}$, com a finalidade de se alcançar \\ delações premiadas ou mesmo a confissão. Notamos, neste aspecto, que o
}

sobretudo como o Racismo Institucional se revela através da seletividade penal que aprisiona mais homens negros e mulheres negras pobres. Cartesianamente, foi demonstrado que um país que tem um índice de crescimento de $7 \%$ ao ano de sua população carcerária, não pode ser chamado de "país de impunidade", muito menos podemos crer o Rio de Janeiro como um estado que não responde ao apelo punitivo da sociedade, registramos em 2016 um índice de $25 \%$ da população carcerária fluminense, alcançamos o absurdo número de 50.000 pessoas presas. É necessário o esforço na integração de ações no âmbito estadual, nacional e internacional de modo a promover uma nova cultura na sociedade brasileira e, principalmente, nas instituições que compõem o sistema de justiça criminal. O Estado brasileiro deve reafirmar sua obrigação e compromisso na inegociável e urgente erradicação da tortura." Documento disponível em: $<$ http://mecanismorj.com.br/relatorios/>. Acesso em: 30 mai. 2017.

${ }^{280}$ A respeito do tema, importante a leitura dos memoriais apresentados pelo IBCCRIM (Instituto Brasileiro de Ciências Criminais), apresentado na qualidade de amicus curiae aos autos da Arguição de Descumprimento de Preceito Fundamental - ADPF no 395, ajuizada pelo PT junto ao STF, com o objetivo de que a condução coercitiva, prevista no artigo 260 do Código de Processo Penal, seja declarada inconstitucional. Aqui vão destacados alguns argumentos de instituições do Estado, rebatidos pelo IBCCRIM, pois reforçam um sistema inquisitivo: “(...) A Presidência da República, de início, sustentou que o direito ao silêncio não assegura ao acusado a possibilidade de não se fazer apresentar ao juiz quando solicitado - o que, francamente, não faz muito sentido: se o acusado, informado de seus direitos, decide não falar, por quê obrigá-lo a comparecer ao Juízo? (...) A Presidência inverteu a lógica dos direitos fundamentais, subordinando a juridicidade de uma ação à sua conveniência, em nítida, bem conhecida e lamentável manobra utilitarista. (...) Senado Federal (...) trouxe aos autos, também, uma versão desatualizada do conceito de interrogatório, que deixa de ser meio de defesa para se constituir em meio preferencial de prova, consoante a lógica punitiva do processo inquisitório e sua obsessão com a confissão como rainha das provas. (...) $\mathrm{O}$ problema imediato é que, sem especificar quais meios são admissíveis para o fím de "extração da Verdade", o Senado flerta perigosamente com a legitimação da tortura física ou psicológica, desde que alcançado o objetivo de demonstrar a responsabilidade penal do imputado. (...) é, sem dúvida, uma parte importante desse teatro inquisitório, que antecipa uma heurística de condenação, promove a ideia de eficiência do sistema de justiça criminal, pressiona o conduzido a "colaborar" e, de certo modo, refrigera o anseio social e imediato por punição. (...) Se somarmos a isso a restrição de acesso à um advogado e a falta de tempo para análise detalhada do inquérito, que impossibilitam a formulação de uma narrativa coerente de defesa, a confissão - ou, melhor ainda, a delação - aparecem como únicas opções razoáveis, para júbilo das agências de repressão. Nada mais útil, como não hesitem admitir em suas manifestações as autoridades que explicitamente se beneficiam do expediente. Por outro lado, nada mais ilegal. A mínima exigência de prévia intimação, solenemente ignorada, seria, por si só, bastante eficaz para esvaziar esse uso alternativo da condução em busca de confissão ou delação (...). al disfarçada de interpretação, o que é simples violação do texto legal, essa prática completamente arbitrária lamentavelmente também contribui para a degeneração de outros direitos fundamentais, como a proteção da honra e imagem e a garantia de presunção de inocência, irreversivelmente maculadas. A odiosa lembrança da prisão para averiguação desperta um forte sentimento de déjà vu. Mais não é preciso dizer, ao menos no que se refere à descrição de um violento contexto afim somente ao Estado de Polícia.” Disponível em: <http://s.conjur.com.br/dl/sustentacao-oral-ibccrim-coercitiva.pdf $>$. Acesso em: 30 mai. 2017. O Conselho Federal da Ordem dos Advogados do Brasil - CFOAB também ajuizou ADPF com objetivo "de que seja reconhecida a não recepção pela Constituição Federal de 1988 do artigo 260, do Código de Processo Penal, no que concerne a sua aplicação no âmbito das investigações criminais, ante a incompatibilidade com os preceitos fundamentais constitucionalmente previstos.": Trata-se da ADPF $\mathrm{n}^{\mathrm{o}} 444 / \mathrm{STF}$. Ver mais em: $<$ http://www.stf.jus.br/portal/cms/verNoticiaDetalhe.asp?idConteudo=338948>. Acesso em: 30 mai. 2017. 
instrumento da delação premiada ${ }^{281}$ foi reinserido e regulamentado no ordenamento jurídico brasileiro em um contexto de instrumentalização da repressão às jornadas de junho de 2013, através da Lei de Organizações Criminosas (item 3.2).

Não é por outro motivo que características do sistema inquisitório permanecem até hoje nas práticas processuais penais do poder constituído: com intento de manter-se onde está, o poder constituído lança mão de práticas inquisitivas com objetivo de controlar a sociedade através da repressão de ações que o colocam em risco.

O juiz como senhor das provas - e, com isso, inequivocamente parcial - caracteriza o pressuposto fundamental do sistema inquisitório, existindo, outros elementos que, como Jacinto informa, são secundários, visto que um sistema misto - como todos atualmente são - pode ser essencialmente inquisitório sem apresentar algumas destas características, por exemplo. O processo inquisitivo se apresenta, em regra, como um processo sigiloso, escrito, sem contraditório, admite denúncia anônima para a sua instauração e a sentença não faz coisa julgada.

O modelo acusatório do processo penal pressupõe a vinculação entre os princípios da imparcialidade e do contraditório, apresentando-se diametralmente oposto ao modelo inquisitório, destacando-se que este modelo destrói a estrutura dialética do processo penal com a gestão da prova nas mãos do juiz:

A gestão /iniciativa probatória nas mãos do juiz conduz à figura do juiz-autor (e não espectador), núcleo do sistema inquisitório. Logo, destrói-se a estrutura dialética do processo penal, o contraditório, a igualdade de tratamento e oportunidades e, por derradeiro, a imparcialidade - o princípio supremo do processo. (...) A imparcialidade é garantida pelo modelo acusatório e sacrificada no sistema inquisitório, de modo que somente haverá condições de possibilidade

\footnotetext{
281 'Nas 'delações premiadas', as informações selecionadas a partir de critérios subjetivos (não raro, condicionados por perversões inquisitoriais e desejos de punir) dos agentes encarregados da persecução penal, são mais importantes do que a descoberta da verdade. A descoberta da verdade torna-se acidental (a verdade deixa de ser uma meta, ou melhor, desaparece o objetivo de se aproximar da verdade no processo penal). Por 'verdade' (poder-se-ia dizer aqui 'pós-verdade') passa a ser entendida a confirmação discursiva da hipótese acusatória." CASARA, Rubens. Das flores vencendo canhões: Poder Penal e Psicopoder versus Poesia. São Paulo, Justificando, 8 abr. 2017. Disponível em: <http://justificando.cartacapital.com.br/2017/04/08/das-flores-vencendocanhoes-poder-penal-e-psicopoder-versus-poesia/>. Acesso em: 03 jun. 2017.
} 
da imparcialidade quando existir, além da separação das funções de acusar e julgar, um afastamento do juiz da atividade investigatória/instrutória. ${ }^{282}$

Geraldo Prado nos ensina que o duelo entre acusação e defesa corolário do princípio acusatório - deve ser observado mesmo na fase préprocessual, de modo que o reconhecimento dos meios de prova obtidos nesta fase é admitido apenas "se conferir suporte probatório mínimo à pretensão ou se a defesa intervier, plenamente, corroborando a sua aquisição, em atividade antecipatória da aquisição e preservação de provas para o futuro",283.

Com isso, o autor ressalta que a distinção entre os princípios inquisitivo e acusatório se dá não só na diferenciação entre juiz e acusador, mas também em relação às "novas maneiras de o imputado participar do processo (...) sob pena de o processo converter-se em instrumento de manipulação política de pessoas e situações"284.

Concordamos com o autor quando reforça que o sistema inquisitivo não é só uma forma de processo, mas uma cultura que existe mesmo quando a base normativa dispõe no sentido contrário (acusatório), o que se dá pelo sentimento de insegurança explorado pela mídia. Explica Geraldo Prado que:

\begin{abstract}
A preferência por uma estrutura processual estranha aos modelos garantistas, se por um lado pode incentivar a produção de leis e decisões incompatíveis com a direção constitucional, reservando a esta incômoda posição de mera promessa, por outro não está imobilizada, petrificada e, portanto, imune aos resultados sociais decorrentes da implementação da opção democrática no âmbito do processo penal. ${ }^{, 285}$
\end{abstract}

Jacinto afirma que o sistema inquisitório é o "pilar-mor" do nosso sistema processual penal ${ }^{286}$, afirmando que o nosso princípio unificador é o inquisitivo ${ }^{287}$ e que a única solução que vislumbra para ultrapassar a estrutura inquisitorial seria acabar com a figura do inquérito policial. O autor entende que à polícia deveria permanecer a função de investigação dos fatos, a partir da qual, o Ministério Público possa formular sua pretensão e, então, poder-se-

\footnotetext{
${ }^{282}$ LOPES JÚNIOR, 2017, p. 163.

${ }^{283}$ PRADO, 2005, p. 120.

${ }^{284}$ Ibid., p. $120-121$.

${ }^{285}$ Ibid., p. 38-39.

${ }^{286}$ COUTINHO, $2001 \mathrm{a}$, p. 31.

${ }^{287}$ Id., 2009, p. 257.
} 
ia realizar uma única instrução, sob o crivo do contraditório, mantendo-se o juiz distante da colheita da prova.

Essa medida seria para evitar, como ocorre no caso brasileiro, que a prova colhida na inquisição do inquérito policial seja integralmente levada ao processo, servindo para justificar uma condenação que, na verdade, está estruturada em princípios do sistema inquisitivo. Aury Lopes explica que isso consiste em uma fraude, bastando o juiz imunizar o discurso através de falácias como "prova corroborada em juízo", para condenar com base "naquilo feito na pura inquisição"288.

Para nós, fica evidenciado que, enquanto o sistema acusatório privilegia o duelo entre acusação e defesa, reproduzindo, ao nosso ver, a democracia do dissenso, o sistema inquisitivo reproduz um pensamento autoritário, na medida em que parte de verdades absolutas que retroalimentam determinadas condutas com o objetivo de não haver mudanças no status quo.

A fim de demonstrar a instrumentalização do Estado para promover a violenta repressão ao poder constituinte das ruas em 2013, através de meios próprios de um sistema inquisitorial, serão considerados os três casos anteriormente discutidos, que fortalecem instituições tradicionalmente autoritárias. Para essa abordagem, oportuno lembrar das palavras de Jacinto Nelson de Miranda Coutinho, quando diz que "há uma imensa diferença entre um discurso crítico tão-só legitimador do status quo e aquele que, agora, precisa dar conta das novas práticas democráticas" 289 .

As jornadas de junho de 2013 nos demonstraram que a repressão ao poder constituinte evidenciou para toda a sociedade as práticas arbitrárias do Estado - desde sempre destinadas aos pobres, favelados, indígenas, trabalhadores rurais etc. - que chegaram às ruas do Rio de Janeiro com a (quase) mesma desproporção existente, por exemplo, nas favelas cariocas porque lá, como falamos, a bala não é de borracha. Essas práticas ganharam chancela de parte da sociedade através da grande mídia que, igualmente interessada na manutenção do status quo, criou estereótipos e estigmatizou os resistentes. Essa estratégia da grande mídia, além de ser recorrente,

\footnotetext{
${ }^{288}$ LOPES JÚNIOR, 2017, p. 161.

${ }^{289}$ COUTINHO, 2001b, p. 4.
} 
retroalimenta uma política criminal perversa de combate aos muitos que querem parte do que é de poucos.

O desafio que a repressão de 2013 nos propõe é o de pensar sobre a viabilidade da utilização do processo penal como forma de contenção das arbitrariedades reiteradamente cometidas contra aqueles que não se beneficiam da manutenção do status quo, através do exercício e da exigência de um processo penal democrático. O trabalho também nos provoca a ultrapassar eventual contradição em termos, pois é pressuposto do processo penal a existência de uma política criminal nada isenta, justamente porque inserido num sistema de justiça interessado em manter esse estado de coisas desigual.

De outro lado, pensar em um processo penal que privilegie sua aplicação mais democrática é considerar a possibilidade de as atividades policial e jurisdicional, mesmo que estejam sob a égide de legislações que refletem determinada política criminal, não compactuarem para o reforço de práticas próprias de um sistema inquisitorial e autoritário, que viabilizam e perpetuam a desigualdade social.

Isso, ao nosso entender, só poderia ser possível se fossem trazidas, para dentro da atividade policial e jurisdicional, algumas formas de resistência a essas práticas decorrentes da política criminal do poder constituído. Uma forma de resistência, por exemplo, é uma "consciente tomada de posição, pelos chamados profissionais (operadores) do direito, sobre a importância de aplicar as regras processuais tendo em vista o fio condutor dos direitos fundamentais" 290 .

\section{2.}

\section{A Política Criminal Autoritária nas Jornadas de Junho de 2013}

Enxergamos, então, a razão pela qual a repressão às jornadas de junho é exemplo da manutenção do pensamento inquisitorial do poder constituído: ante a necessidade de manter-se onde estão, extraem-se verdades que estigmatizam manifestantes, tratando-os como inimigos que, por isso, não são

\footnotetext{
${ }^{290}$ PRADO, 2005, p. 51.
} 
destinatários de direitos e garantias fundamentais, o que é incentivado pela grande mídia, formando um ciclo vicioso de combate aos muitos que desejam o que é de poucos.

A CEIV (item 3.2.1), sob o crivo de uma questionada "necessidade de celeridade", determinou que os seus requerimentos tramitassem com urgência em órgãos públicos e privados, inclusive solicitando às operadoras de telefonia, em sua primeira versão publicada, o descumprimento de lei federal que obriga autorização judicial para a quebra de sigilo telefônico. Para tanto, invocou "atos de vandalismo" sem que tais ações tivessem previsões típicas no direito penal brasileiro.

Ainda a respeito da CEIV, cuja presidência foi exercida pelo Ministério Público do Estado do Rio de Janeiro - órgão que tem a sua existência fundada na necessidade de observância das leis e da Constituição -, não obstante a existência da Lei de Acesso à Informação, nos negou acesso, por duas vezes, ao conteúdo das investigações realizadas no âmbito daquela Comissão, sob o argumento de que a Comissão:

(...)foi instituída com o objetivo de facilitar o trabalho e a tomada de ações coordenadas entre o Ministério Público do Estado do Rio de Janeiro e as Polícias Civil e Militar do Estado do Rio de Janeiro, não havendo registros públicos de suas reuniões durante o lapso temporal de sua existência"291 (grifos meus).

Nos soa evidente que a arguição injustificada de sigilo é o maior exemplo de pensamento inquisitivo, no contexto da CEIV, do próprio órgão originalmente criado para fiscalizar a lei e o cumprimento da Constituição.

O exemplo do decreto do Poder Executivo que criou CEIV corresponde, ao nosso ver, àquilo que Foucault denominou de "o terror ubuesco, a soberania grotesca" que, para ele, é uma das engrenagens dos mecanismos de poder e sempre esteve "na estrutura, no funcionamento político das nossas sociedades". Para o autor, o grotesco é essencial ao poder arbitrário, de modo que compreendemos, com isso, que o grotesco decreto se alinha exatamente com esse pensamento ${ }^{292}$.

\footnotetext{
${ }^{291}$ Remetemos à nota de rodapé $\mathrm{n}^{\mathrm{o}} 184$.

${ }^{292}$ FOUCAULT, 2002, p. 15.
} 
Ante à própria natureza escusa e sigilosa da estrutura inquisitória, é impossível alcançarmos todos os atos grotescos do poder constituído que engrossam o discurso inquisitivo dos agentes do sistema de justiça penal.

De outro lado, como já falamos, a aplicação da Lei de Organizações Criminosas para justificar a prisão cautelar de dezenas de jovens e professores no dia 15 de outubro de 2013 é, igualmente, própria de uma estrutura inquisitória. Essa visão é reforçada quando lembramos que muitas daquelas pessoas presas juntas, jamais haviam se visto, não se uniram para praticar crimes e tampouco auferiram qualquer vantagem ao manifestarem juntos, de certo que suas ações não correspondem ao tipo penal de organização criminosa, não obstante muitos terem ficado uma semana ou mais presos.

Ao nosso ver, dos marcos trazidos por esse trabalho, que têm por objetivo demonstrar a instrumentalização da repressão ao poder constituinte nas ruas em 2013, certamente o "processo dos 23" é o que mais pontua nos quesitos de características do princípio inquisitivo.

A par da nossa análise ter sido feita nos dois inquéritos ${ }^{293}$ - que tradicionalmente têm natureza inquisitiva, pela "ausência do contraditório" -, a natureza inquisitória do inquérito não autoriza, por óbvio, o desrespeito às garantias fundamentais do investigado, muito menos que tais violações sejam endossadas pelo órgão fiscalizador (isto é, o Ministério Público) e pelo juiz que, ao contrário, deveriam refutá-las.

Como exemplo, lembramos o caso da jovem que sofreu busca e apreensão e, ainda, foi conduzida ilegalmente (posto que sem mandado anterior, tampouco sem mandado de condução coercitiva) à DRCI. Ao chegar na delegacia, a jovem teve negado o seu direito de permanecer calada - e/ou de não produzir prova contra si - , sob a justificativa de que estaria sendo ouvida como testemunha (que, frise-se, sofreu busca e apreensão). Além disso, após tentar arguir o seu direito de ficar em silêncio, sofreu coação, no sentido de que, caso não colaborasse, a sua prisão poderia ser ali mesmo decretada. Para nós, esse é o retrato de um Estado autoritário, estruturado no pensamento inquisitorial.

${ }^{293}$ Porque a ação penal originada por estes procedimentos ainda aguarda a sentença. 
Certamente, a análise de todas as violações às garantias constitucionais dos investigados no inquérito que originou o "processo dos 23 " nos permitiria redigir um trabalho inteiro com vistas a denunciá-las. Esse não é, portanto, o nosso objetivo aqui, senão o de demonstrar, a partir destes marcos, que a repressão violenta e autoritária ao poder constituinte implicou em grave ameaça à democracia absoluta que, a partir do dissenso, buscava alcançar melhorias em suas condições de vida.

Nesta linha, vimos acima que são inúmeros exemplos de ilegalidades que, ao nosso ver, reforçam dentro do sistema penal, assim como junto à sociedade, um pensamento inquisitorial que não encontra amparo na Constituição de 1988, mas que o encontra na grande mídia, que retroalimenta esse sistema penal autoritário e que estigmatiza as minorias, discriminando-as.

Uma consequência automática da manutenção da lógica inquisitiva pelos agentes do sistema penal e (também) da sociedade, entendemos ser o fortalecimento das instituições que agem nessa estrutura antidemocrática. Logo, as ações direcionadas aos inimigos - e o são porque não desejam manter o status quo - implicam em verdadeira discriminação entre aqueles que têm direitos e aqueles que não têm, cabendo aos que não os têm uma violência estatal incompatível com os pressupostos da Constituição democrática de 1988.

Casara nos lembra que não houve verdadeiramente uma ruptura com o nosso passado autoritário e que "a transição proporcionou a acomodação entre os setores governamentais, que representavam parte da elite, e algumas das principais forças oposicionistas, de modo tal que estruturas e mesmo pessoas do antigo regime se incorporaram ao novo" ${ }^{, 294}$. Para o autor, todos os que não interessam à "razão neoliberal” são etiquetados ${ }^{295}$ para que sejam excluídos ou controlados pelo que chama de "Estado Pós-Democrático".

No grupo dos etiquetados como desinteressantes (porque obstaculizam os interesses neoliberais) encontram-se não só os que não correspondem aos interesses econômicos do neoliberalismo, mas também aos seus interesses

\footnotetext{
${ }^{294}$ CASARA, 2016.

295 “'(...)'falhas de caráter', 'deficiências comportamentais', 'preguiça para o trabalho', 'rebeldia' ou qualquer outra etiqueta neoliberal” (grifos meus). Ibid.
} 
políticos ${ }^{296}$, já que é desejado manter a razão neoliberal no controle político, de modo que o sistema de justiça é articulado para que esses interesses sejam mantidos:

O recurso ao Sistema de Justiça para afastar esses obstáculos materiais e simbólicos também é um sintoma do Estado Pós-Democrático, no qual o Poder Judiciário deixa de reconhecer limites ao exercício do poder para funcionar em sentido contrário, mais precisamente como um instrumento voltado à eliminação dos obstáculos aos interesses repressivos do Estado ou do mercado. Isso se dá porque a razão neoliberal passou a condicionar a atuação dos atores jurídicos que, ainda que inconscientemente, abandonam a pretensão de servirem como garantidores dos direitos fundamentais. ${ }^{297}$

Por esta razão é que o mesmo autor invoca a importância do Judiciário como garantidor da democracia enquanto protetor dos direitos e garantias fundamentais constitucionalmente previstos, sem rendição às "maiorias de ocasião", já que "afastar ou 'relativizar' direitos e garantias é sempre um passo ao autoritarismo",298.

Esse passo, ousamos dizer, já é dançado cotidianamente nas periferias contra os pobres desinteressantes à manutenção do status quo, em um verdadeiro ritual de terror e ódio. A repressão autoritária não é novidade no Brasil, tampouco é velada.

Nos coube neste trabalho, então, perceber que a repressão já cotidiana nas periferias (que, quando veiculada, é aplaudida e incentivada por boa parte da sociedade telespectadora da grande mídia) se tornou ainda mais pública, através dos meios de comunicação de massa, quando alcançou os manifestantes das ruas de 2013. Com toda a sua parcialidade, assim como é quando a notícia é sobre a favela, a grande mídia promoveu ainda mais um discurso de ódio que fortalece as instituições autoritárias que, em detrimento dos direitos e garantias fundamentais de todos, excepcionam sua aplicação aos inimigos estrategicamente construídos.

Ao que nos parece, como bem colocado por Pedro Serrano, é que presença das medidas autoritárias (tratamento excepcional destinada a

\footnotetext{
296 "Os indesejados para os detentores do poder econômico, porém, não se resumem àqueles incapazes de produzir ou consumir mercadorias. Existem também os inimigos políticos que representam, ou ao menos simbolizam, uma ameaça ao controle político do Estado." (grifo meu) CASARA, 2016. ${ }^{297}$ Ibid.

${ }^{298} I d ., 2017$.
} 
determinada parcela da sociedade), "passa a ser estruturante, passa a ser um modo para produzir autoritarismos na democracia". Trata-se de um sistema que "ao invés de universalizar os direitos fundamentais (...) universaliza a injustiça que atinge a população pobre"299.

A recente pesquisa de maio de 2017 publicada pelo Centro de Estudos de Segurança e Cidadania da Universidade Cândido Mendes (CESEC/UCAM), realizada no Rio de Janeiro sob a coordenação dos professores Julita Lemgruber, Ignacio Cano e Leonarda Musumeci, que buscou "captar perfis, ideias, percepções e valores relacionados à ideologia do justiçamento e da rejeição aos direitos humanos na área da justiça criminal" 300 , observou que:

A ditadura civil-militar de 1964-85 alimentou e aprofundou a tradição autoritária brasileira, que não foi nem de longe superada com a Constituição de 1988. Valores liberais-democráticos, constitucionais, continuam ausentes tanto do pensamento popular quanto do da grande maioria dos operadores do sistema de segurança e justiça. Resiste-se fortemente à imposição de limites ao poder punitivo do Estado: direitos e garantias são vistos como obstáculos à eficiência repressiva estatal e vê-se no uso da força o principal, senão o único, meio de resolução de conflitos. É curioso notar que a população geralmente não confia nas leis penais e na Justiça por considerá-las "frouxas", lenientes, prejudiciais ao controle da criminalidade ("polícia prende, juiz solta" é um dos clichês denotativos dessa visão). Entretanto, o Judiciário - dos tribunais estaduais ao STF - tem atuado cada vez mais, no pós-ditadura, para garantir a ausência de limites e a maximização do poder punitivo. Há uma quase total colonização do pensamento pelo discurso do incentivo à força em detrimento do conhecimento. ${ }^{301}$

Nos soa claro que essa colonização do pensamento pelo discurso punitivo é refletida também na repressão violenta, que identificamos na instrumentalização do Estado de mecanismos legais para implodir os movimentos constituintes. As ações contra as jornadas de 2013 somam a esse pensamento e perpetuam instituições autoritárias que há tempos - pelo menos

\footnotetext{
${ }^{299}$ Entrevista concedida pelo Professor Pedro Serrano ao site Sul 21, reproduzida na coluna eletrônica Justificando da Revista Carta Capital, em 25 de outubro de 2016. Disponível em: $<$ http://justificando.cartacapital.com.br/2016/10/25/para-pedro-serrano-o-papel-do-sistema-dejustica-esta-substituindo-o-papel-dos-militares/>. Acesso em: 31 mai. 2017.

${ }^{300}$ LEMGRUBER, CANO \& MUSUMECI, 2017, p. 5.

301 "O levantamento do CESeC, numa amostra de 2.353 moradores da cidade do Rio de Janeiro com 16 anos ou mais de idade, procurou captar, adicionalmente, perfis, ideias, percepções e valores relacionados à ideologia do justiçamento e da rejeição aos direitos humanos na área da justiça criminal. Combinando pesquisa amostral e entrevistas abertas com especialistas, o trabalho busca aprofundar o conhecimento do tema e subsidiar ações e campanhas que abram possibilidades de sensibilização e mudança." Ibid., p. 39.
} 
de 1988 - deveriam adotar práticas democráticas, sobretudo em relação a garantia dos direitos fundamentais de e para todos. Mas também nos soa claro que interesses econômicos, agenciadores da política do poder constituído, não desejam a emancipação, através da fruição de direitos legítimos, daqueles que não atendem às expectativas econômicas dos grandes grupos ${ }^{302}$.

Mais uma vez, destacamos que se trata de um círculo vicioso que apenas poderá ser interrompido através da luta destemida nas ruas.

A questão que se coloca é que o Estado repressor e autoritário não observa os limites constitucionais quando se está em risco a ordem estabelecida. Com isso, as instituições - mesmo aquelas que deveriam, por lei, preservar direitos, como o Ministério Público - endossam e reforçam o discurso de guerra ao inimigo.

A convocação da Força Nacional nas jornadas de junho de $2013^{303}$ é um exemplo disso, mas também a existência de policiais militares sem identificação, a desproporcional violência implementada contra os sujeitos insurgentes, a decretação de ato do Executivo (a CEIV) solicitando descumprimento de Lei Federal, a aplicação de lei severa sem adequação típica às ações dos manifestantes (Lei de Organizações Criminosas), as "prisões para averiguação", as violações às prerrogativas de advogados e aos direitos dos investigados (tratados como inimigos na DRCI), a decretação da prisão de professores e jovens tão somente porque desejavam destruir o

\footnotetext{
302 "Junto com o arcabouço institucional e o regime de exceção policial, herdou-se dos governos militares a concepção bélica da segurança pública, manifesta claramente nas expressões 'guerra às drogas' e 'combate ao crime' - concepção que toma o criminoso como inimigo, portanto desprovido de direitos e eliminável. É nessa 'ideologia da defesa social' que se ancora não só a ação das polícias como de todo o sistema de segurança e justiça, supondo uma clara definição do 'bem' e do 'mal', e uma inequívoca identificação do bandido com o 'homem do mal' de quem é preciso a qualquer custo defender os assim chamados 'cidadãos de bem'. (...) Índice de agravamento do autoritarismo, essa fruição também inclui a recusa a admitir, para quem comete um crime, qualquer espécie de proteção contra o poder absoluto, o sofrimento, a desumanização ou a morte. Execução e prisão sem limites, sem 'privilégios' (leia-se: sem garantias e benefícios legais) são vistas como únicas formas efetivas de castigo. Consequentemente, penas alternativas à prisão, assim como a observância do devido processo legal e o respeito a direitos e garantias são interpretados como impunidade. (...) Essa convergência de opiniões e desejos entre setores dominantes e dominados mostra bem que controle e poder não se dão apenas pelas armas, pela força, mas também no campo das ideias. E que a 'colonização do pensamento' por parte do autoritarismo, mesmo entre suas vítimas preferenciais, é pervasiva e altamente eficaz." LEMGRUBER, CANO\& MUSUMECI, 2017, p. 46.

303 Vide na notícia do Jornal O Dia, de 19 de junho de 2013. Disponível em: $<$ http://odia.ig.com.br/noticia/rio-de-janeiro/2013-06-19/rio-tera-blindados-nas-ruas-e-auxilio-daforca-nacional.html>. Acesso em: 20 mai. 2017.
} 
abismo colocado entre eles - poder constituinte em movimento - e o poder constituído.

Devemos, então, pensar em como romper esse círculo vicioso que corrói a democracia sob aplausos dos poucos que têm muito, discriminando não só os que têm pouco, mas também os que percebem a realidade discriminatória e autoritária das instituições e contra elas propõem-se a insurgir-se.

Se concordamos com Negri que, a partir de Maquiavel, compreende que é do dissenso que surge a boa ordem da democracia e com Geraldo Prado $^{304}$, quando afirma que o duelo no processo democrático é entre a acusação e defesa, apenas, sem dúvidas a melhor maneira de reduzir o abismo entre sociedade e poder constituído é através da criação de condições para que esse espaço de luta - nas ruas e no processo - não seja apropriado por instituições autoritárias que, ao fim e ao cabo, não desejam mudança alguma.

304 “(...) a tensão dialética natural da democracia projeta-se no âmbito da solução institucionalizada dos conflitos de interesses como sendo a melhor, senão a única forma de adjudicação de soluções a estes conflitos, modulando o instrumento conforme o paradigma político e deferindo ao juiz a legitimidade necessária à enunciação das decisões.” PRADO, 2005, p. 32. 


\section{Conclusão}

Os jovens das ruas de 2013 protagonizaram uma ação democrática que, embora tenha se sustentado por pouco tempo junto ao poder constituído fluminense, demonstrou sua potência transformadora a partir da vontade da multidão. A ideia de poder constituinte negriano - que, a partir de Maquiavel, compreende que a boa ordem é alcançada pelo dissenso - se fez presente nas ruas do Rio de Janeiro, através de lutas constituintes e desestruturantes. Tratou-se de vivência real e prática da democracia, dada a espontaneidade da multidão que, através de movimentos em rede, interagiam e davam voz às suas reivindicações.

Nos é certo que o palco para a tensão entre o poder constituído transcendente e o poder constituinte imanente e constante, representado sob a forma de multidão, deveria ser, como Negri e Castells propõem, respectivamente, as ruas com auxílio das redes, onde ocorrem as lutas constituintes ou desestruturantes. Ao contrário disso, nunca devem se dar por meio de uma composição pois, através desta, o poder constituinte permanecerá massacrado e reprimido em nome da alegada necessidade de manutenção, à força, do poder constituído transcendente.

Sob essa perspectiva, entendemos que, no Rio de Janeiro, acompanhando um movimento mundial, o espaço virtual e permanente dos movimentos em rede promoveu encontros e conexões que estimularam jovens a lançarem-se às ruas com suas pautas democráticas, intencionando diminuir o abismo imposto entre os que são e aqueles que não são interessantes ao poder econômico. O distanciamento dos que não interessam economicamente os aproxima do conceito de inimigo do Estado, e estes acabam sendo estigmatizados e criminalizados. Isso ocorre especialmente quando os 
desinteressantes se rebelam contra o status quo, cuja manutenção interessa à sociedade global de controle. Esta, por sua vez, funciona simultaneamente como fomentadora e como estabilizadora da desigualdade, que é aumentada com o incremento da repressão do Estado, através da qual conceitos como inimigos da sociedade são criados com o objetivo de manter as coisas como estão, dispensando aos ditos inimigos tratamento jurídico diferenciado, próprio de um estado autoritário. Para nós, a lógica da criação do inimigo esteve presente nas ações do Estado contra as jornadas de junho de 2013, especialmente através dos mecanismos de repressão instrumentalizados com o objetivo de reprimir a multidão constituinte.

A implosão das jornadas de 2013 através de violenta repressão colaborou para a manutenção do pensamento inquisitorial e para o fortalecimento de instituições autoritárias, o que nos desafiou a refletir sobre a viabilidade do uso do processo penal como meio de contenção das arbitrariedades reiteradamente cometidas contra aqueles que não se beneficiam da manutenção do status quo. Em outras palavras, a utilização do processo penal como instrumento de proteção das garantias fundamentais do acusado que, muitas vezes, em última análise, vira parte de determinado processo devido a alguma violação anterior cometida pelo Estado.

A utilização da dialética processual penal como espaço de disputa democrática, sem intervenções de juiz parcial, tampouco sem estigmas generalizantes, permitiria a efetivação de garantias fundamentais emancipatórias daqueles que estão cotidianamente no alvo das políticas de repressão estatais. Se, por um lado a política criminal do Estado é originalmente parcial porque pretende manter as coisas como estão, por outro lado é urgente e necessário que os operadores de direito tomem parte de sua função na democracia - como essencial à justiça - e promovam um processo penal verdadeiramente democrático, com todas as garantias do indivíduo.

Isso nos é claro porque, enquanto advogada voluntária nas ruas em 2013, na tentativa de persuadir alguns contra a instrumentalização antidemocrática de meios de repressão, parecíamos falar em vão. Fora do contexto da multidão constituinte, dos socorristas, dos midialivristas e dos advogados voluntários, era difícil aproximar-nos de amigos e familiares para explicar a distorção da grande mídia, não adiantava gritarmos por eles a favor 
daquela democracia real e latente nas ruas. Muitos daqueles que não estiveram nas ruas ainda não compreenderam o significado daqueles momentos, inclusive a esquerda governista, e temos dúvidas quanto a possibilidade de um dia compreenderem. Muitos destes bateram panelas anos depois...

Ao fazer a presente pesquisa, contatando algumas pessoas que me recordo de ter ajudado ou a algum familiar seu, recebi mensagens como "Jamais esqueceria de você. E quando te vejo tenho um sentimento de agradecimento.”305. Pequenos gestos como esse de gratidão pelo trabalho do coletivo enchem-me de esperança e desejo de que a multidão não mais esbarre os dedos ${ }^{306}$ no futuro ansiado, mas que o possa desenhar com o mesmo dissenso democrático, absurdamente valioso, antes, inclusive, que seja tarde.

É por isso que insistimos em afirmar que a democracia não está garantida porque a nossa Constituição só é democrática de um ponto de vista formal. Para muito além disso, a democracia material só estaria garantida se o poder constituído permitisse romper o distanciamento e ouvir as ruas, abrir o diálogo com os movimentos insurgentes, não os privar dos direitos que poucos têm em detrimento dos muitos.

Entendemos que, quantas vezes a participação da multidão e seu dissenso não forem aceitas pelo poder constituído como prática democrática, o mesmo número de vezes é permitido à multidão insurgir-se contra a violação dos seus direitos garantidos.

O sistema processual penal, através de todos aqueles que dele fazem parte, deverá servir como barreira de contenção aos excessos do poder constituído interessado em calar violentamente a voz das ruas, o que devem fazer impedindo ou rejeitando a repetição de práticas processuais inquisitivas e autoritárias que só objetivam a manutenção do status quo. Os operadores do direito, professores, juristas etc. devem compreender que apenas desta forma é que se permite o fortalecimento da democracia que se pretende, bem distante daquela que cada vez mais nos cerca. É urgente e necessário pular a cerca.

\footnotetext{
305 Mensagem recebida por Daniela Ribeiro, irmã do cineasta Victor Ribeiro, preso na manifestação do dia 15 de outubro e levado para a unidade prisional Patricia Acioly, onde fui visitá-lo antes de ser transferido para Bangu.

${ }^{306}$ Refiro-me ao artigo do professor Adriano Pilatti, no qual escreveu, em janeiro de 2014: “O ano que terminou mas não acabou, o ano em que ninguém voltou da rua do mesmo jeito, o ano em que nos comprometemos amorosamente com o mundo futuro que quase chegamos a tocar com as pontas dos dedos. Havemos de alcançá-lo.” PILATTI, 2014, p. 64.
} 
A presença do Estado-policial nas ruas e no sistema de justiça penal com o fim de conter o movimento constituinte demonstra, a contrário senso, a força que a insurgência democrática possui. É também por esse motivo que o poder constituído só dá conta de manter o status quo quando armado com as lanças do Judiciário e protegido com o escudo da grande mídia, momento em que:

(...) optam por montar-se sobre o aparelho autista e sancionar leis penais e processuais autoritárias e violadoras de princípios e garantias constitucionais, prever penas desproporcionadas ou que não podem se cumprir porque excedem a vida humana, reiterar tipificações e agravantes em confusões, sancionar atos preparatórios, desarticular os códigos penais, sancionar leis penais por pressões estrangeiras, introduzir instituições inquisitórias, regular a prisão preventiva como pena e, em definitivo, desconcertar os tribunais mediante a moderna legislação penal cool. ${ }^{307}$

A par da discussão proposta neste trabalho, compreendemos que uma combativa resistência ao sistema inquisitivo, de cunho autoritário, é necessária e deve ser exercida por operadores de direito como verdadeira barreira de contenção às violações constantes às garantias direitos fundamentais de todos. Não cabe exceção ao "inimigo" construído porque, enquanto forem toleradas práticas inquisitivas, haverá prejuízo à democracia.

Jacinto, ao afirmar que o sistema processual penal brasileiro é essencialmente inquisitório, discorre que o papel do novo juiz no processo penal compreende a adoção de práticas democráticas direcionadas à emancipação do nosso povo, a partir de uma dogmática ${ }^{308}$ e, sobretudo, através de uma visão interdisciplinar - "pela ultrapassagem das fronteiras atuais da disciplina" 309 .

Pensamos que essa ultrapassagem das fronteiras da disciplina (processo penal) poderia, por exemplo, corresponder a um mínimo esforço para estimular os novos e futuros operadores do direito a construírem um

${ }^{307}$ ZAFFARONI, 2010, p. 35-36. Zaffaroni destaca a vulnerabilidade dos juízes que, neste contexto, também sofrem pressão do "autoritarismo publicitário cool dos meios massivos". Aqueles que proferem sentenças que confrontem tal discurso podem ser estigmatizados ou até mesmo perseguidos, o que permite que políticos e colegas se beneficiessem publicamente com essa perseguição.

${ }^{308}$ Jacinto compreende o sentido de "dogmática" como aquele dado por Plauto Faraco de Azevedo, isto é, como "descrição das regras jurídicas em vigor". AZEVEDO, Plauto Faraco apud COUTINHO, 2001a, p. 7.

${ }^{309}$ MIAILLE, 1989, p. 61. 
pensamento crítico, multidisciplinar, voltado à emancipação da sociedade através da efetivação de seus direitos. Para tanto, acreditamos na ideia de Luis Alberto Warat sobre o desenvolvimento de uma metodologia do ensino crítico como uma ação liberadora do ser humano:

La educación em términos de epistemologia propicia fundamentalmente el desarollo de uma metodologia del aprender crítico. Educar no es así suministrar información sino facilitar el aprendizaje problematizador del aprender. Sólo de esta forma la educación deja de cumplir um mero papel socializador para passar a ser uma acción liberadora del ser humano. ${ }^{310}$

Em obra dividida com Rosa Maria Cardoso da Cunha, Warat e a autora nos mostram que a "transmissão autoritária do conhecimento" nas faculdades de Direito não possibilita que decisões sejam tomadas de forma autônoma:

Toda transmissão autoritária do conhecimento gera como resposta a passiva memorização dos alunos, a construção, por parte dos mesmos, de um conjunto de imagens pré-fabricadas, que servem para lograr um título universitário, mas que não habilitam a decisões maduras e autônomas. (...) As faculdades de Direito devem deixar de ser centros de transmissão de informação para dedicarem-se, prioritariamente, à formação da personalidade do aluno, do advogado, do jurista, de sujeitos que saibam reagir frente aos estímulos do meio socioeconômico. ${ }^{311}$

Essa reação é fundamental para a proposta do presente trabalho, através do qual vislumbramos que a atividade dos operadores de direito deve, sim, ser reativa às opressões do sistema processual, até que advogados, promotores, defensores públicos, estudantes de direito e, sobretudo, magistrados, se tornem instrumentos de resistência democrática. Hoje, ao contrário do que se pretende, eles são cooptados como armas de proteção do status quo.

A conscientização da sociedade em geral a respeito dos seus direitos e garantias fundamentais deve ser também um instrumento de contenção das práticas arbitrárias do poder constituído. Não nos restam dúvidas que qualquer movimento, mesmo que este seja pequeno, que seja capaz de contribuir para que a sociedade tome conhecimento dos seus direitos e garantias, descolonizando o pensamento punitivo, surtiria efeito social, a médio e longo prazo, e que este seria mais benéfico do que qualquer prática punitiva imediatista.

\footnotetext{
${ }^{310}$ WARAT, 2004, p. 364.

${ }^{311}$ WARAT \& CARDOSO, 1977, p. 61.
} 
Sobre a privilegiada relação do Direito com a democracia, coloca Geraldo Prado:

\begin{abstract}
Mas não como uma democracia qualquer, fulcrada na mera declaração formal de respeito aos direitos fundamentais e numa vinculação passiva entre governados e governantes e sim na real democracia participativa, integradora e solidária, com inegável repercussão no plano do processo penal, de sorte que a cultura democrática aos poucos poderá ser desenvolvida pela conscientização da forma democrática da sociedade conviver. ${ }^{312}$
\end{abstract}

Através dessa privilegiada relação, deve, então, haver efetiva resistência pelos juízes à adoção de comportamentos processuais incompatíveis com o sistema acusatório ou democrático, uma vez que, ao reconhecermos que o processo penal é mecanismo de proteção às garantias fundamentais $^{313}$, este torna-se um importante espaço para a afirmação da democracia que pretendemos ${ }^{314}$.

Este espaço não pode, portanto, ser negligenciado e entregue aos interesses do poder constituído formador uma "maioria de ocasião". Isso porque o sistema de justiça deve garantir direitos fundamentais, independentemente de tais proteções corresponderem a interesses contramajoritários.

Se nas ruas a resposta do poder constituído foi repressora, com graves violações aos direitos de todos, sem dúvidas no âmbito dos processos (e inquéritos) a luta pela democracia deveria ser "reiniciada". E, para tanto, imprescindível o afastamento das verdades absolutas e estigmatizantes dos manifestantes que, ao serem etiquetados como "vândalos", imediatamente perderam garantias processuais irrevogáveis.

O que propomos é que a força do movimento constituinte que é canalizada como resistência às opressões seja refletida dentro do sistema de justiça através não só do "novo papel do juiz no processo penal", mas também a partir da assunção de um novo papel de todos os operadores do sistema de

\footnotetext{
${ }^{312}$ PRADO, 2005, p. 40.

313 “(...) na essência, Constituição e Processo Penal lidam com algumas importantes questões comuns: a proteção aos direitos fundamentais e a separação dos poderes". Ibid., p. 41.

314 “(...) em relação ao Sistema Penal, mais do que para qualquer outra área afetada pelas emanações da ordem jurídica, a existência de uma ligação entre direitos fundamentais e poder legítimo, expressão da soberania popular, está radicada na vigência da democracia constitucional." Ibid., p. 27.
} 
justiça, desde as faculdades de Direito, passando pela formação dos agentes de polícia, até o Supremo Tribunal Federal e demais instituições. 


\section{Referências bibliográficas}

BAKER, Eduardo; DAMAZIO, Natália. A segurança nacional e o estilingue. In: CAVA, Bruno e COCCO, Giuseppe, Amanhã vai ser maior: o levante da multidão no ano que não terminou. São Paulo: Annablume, 2014.

BATISTA, Nilo. Introdução crítica ao Direito Penal Brasileiro. $4^{\mathrm{a}}$ ed. Rio de Janeiro: Revan, 2001.

BATISTA, Vera Malaguti. Difíceis ganhos fáceis: drogas e juventude pobre no Rio de Janeiro. $2^{\mathrm{a}}$ ed. Rio de Janeiro: Revan, 2003.

BUSATO, Paulo. Quem é o inimigo, quem é você? Revista Brasileira de Ciências Criminais, v. 15, n. 66, pp. 315-371, maio-jun. 2007.

CARVALHO, Salo. Pena e garantias: uma leitura do garantismo de Luigi Ferrajoli no Brasil. Rio de Janeiro: Lumen Juris, 2001.

Juris, 2008.

. Antimanual de criminologia. $2^{\mathrm{a}}$ ed. Rio de Janeiro: Lumen

CASARA, Rubens. Mitologia processual penal. São Paulo: Saraiva, 2015.

- O Estado Pós-Democrático no Brasil: a gestão dos indesejáveis. Carta Capital, São Paulo, 17 set. 2016. Disponível em: $<$ http://justificando.cartacapital.com.br/2016/09/17/o-estado-pos-

democratico-no-brasil-gestao-dos-indesejaveis/>. Acesso em: 31 mai. 2017.

- Tentação autoritária: A opinião pública não autoriza o afastamento das regras democráticas. O Globo, São Paulo, 03 jun. 2017. Disponível em: <https://oglobo.globo.com/opiniao/tentacao-autoritaria21430663>. Acesso em: 3 jun. 2017.

CASTELLS, Manuel. Redes de indignação e esperança: movimentos sociais na era da internet. $1^{\mathrm{a}}$ ed. Rio de Janeiro: Editora Zahar, 2013. 
. Supera-se o medo com a indignação. Revista IHU, São

Leopoldo, 20 jul. $2015 . \quad$ Disponível em: $<$ http://www.ihu.unisinos.br/noticias/544729-supera-se-o-medo-com-aindignacao-diz-manuel-castells>. Acesso em: 29 jul. 2015.

COCCO, Giuseppe; NEGRI, Antônio; PILATTI, Adriano. Levante da multidão. Valor Econômico, São Paulo, 28 jun. 2013. Disponível em: $<$ http://www.valor.com.br/cultura/3177040/levante-da-multidao>. Acesso em: 1 ago. 2015.

COCCO, Giuseppe; PILATTI, Adriano. Quem tem medo do poder constituinte? Revista IHU, São Leopoldo, 15 jul. 2013. Disponível em: <http://www.ihu.unisinos.br/noticias/521906-quem-tem-medo-do-poderconstituinte>. Acesso em: 02 ago. 2015.

A persistência da democracia absoluta. In: NEGRI, Antônio. O poder constituinte: ensaio sobre as alternativas da modernidade. Tradução: Adriano Pilatti. $2^{\mathrm{a}}$ ed. Rio de Janeiro: Lamparina, 2015.

CORREA, Murilo Duarte Costa. Contra o rosto. In: CAVA, Bruno e COCCO, Giuseppe. Amanhã vai ser maior: o levante da multidão no ano que não terminou. São Paulo: Annablume, 2014.

COUTINHO, Jacinto Nelson de Miranda. Introdução aos princípios gerais do processo penal brasileiro. Revista da Faculdade de Direito da Universidade Federal do Paraná, Curitiba, a. 30, n. 30, 1998.

. O papel do novo juiz no processo penal. In: Crítica à teoria geral do direito processual penal. Rio de Janeiro: Renovar, 2001a.

. Crítica à teoria geral do direito processual penal. Rio de Janeiro: Renovar, 2001b.

. Um devido processo legal (constitucional) é incompatível com o sistema do CPP, de todo inquisitorial. In: MALAN, Diogo e PRADO, Geraldo (coord.), Processo Penal e Democracia: estudos em homenagem aos 20 anos da Constituição da República de 1988. Rio de Janeiro: Ed. Lumen Juris, 2009.

COUTINHO, Jacinto Nelson de Miranda; CARVALHO, Luis Gustavo Grandinetti Castanho de (orgs.). O novo processo penal à luz da Constituição (análise crítica do projeto de lei $n^{0} 156 / 2009$, do Senado Federal). Vol. 2. Rio de Janeiro: Lumen Juris, 2011.

DUPUIS-DÉRI, Francis. Black Blocs. Tradução de Guilherme Miranda. São Paulo: Veneta, 2014.

FELDENS, Luciano; ZENKER SCHMIDT, Andrei. O marco normativo do direito fundamental a um juiz imparcial: do passado ao presente. In: MALAN, Diogo e MIRZA, Flávio (coord.), Setenta anos do Código de 
processo penal brasileiro: balanço e perspectivas de reforma. Rio de Janeiro: Ed. Lumen Juris, 2011, pp. 23-47.

FERRAJOLI, Luigi. Derecho y razón: teoría del garantismo penal. Madrid: Trotta, 1997.

. El derecho penal del enemigo y la disolución del derecho penal. Revista del Instituto de Ciencias Jurídicas, n. 19, pp. 5-22, 2007.

FIUZA, Bruno. Black Blocs: A origem da tática que causa polêmica na esquerda. Viomundo, São Paulo, 8 ago. 2013. Disponível em: $<$ http://www.viomundo.com.br/politica/black-blocs-a-origem-da-tatica-quecausa-polemica-na-esquerda.html>. Acesso em: 22 mai. 2017.

FOUCAULT, Michel. Segurança, território, população: curso dado no Collège de France. São Paulo: Martins Fontes, 2008.

Martins Fontes, 2001.

GUIMARAENS, Francisco. O poder constituinte na perspectiva de Antonio Negri: um conceito muito além da modernidade hegemônica. Dissertação de mestrado (Departamento de Direito). Pontifícia Universidade Católica do Rio de Janeiro. Rio de Janeiro, 2002.

HARDT, Michael. A sociedade mundial de controle. In: Éric Alliez (org.), Gilles Deleuze: uma vida filosófica. Tradução de Maria Cristina Franco Ferraz. São Paulo: Ed. 34, 2000.

. Prefácio - Maldito Junho. In: CAVA, Bruno e COCCO, Giuseppe. Amanhã vai ser maior: o levante da multidão no ano que não terminou. São Paulo: Annablume, 2014.

HARDT, Michael; NEGRI, Antônio. Império. Rio de Janeiro: Record, 2001.

. Multidão: guerra e democracia na era do império. Rio de Janeiro: Record, 2005.

JAKOBS, Günther. Criminalización en el estadio previo a la lesión de un bien jurídico. In: JAKOBS, Günther. Estudios de Derecho Penal. Madrid: Civitas, 1997, pp. 322-323.

LOPES JR., Aury. Direito processual penal. $11^{\mathrm{a}}$ ed. São Paulo: Saraiva, 2014. Saraiva, 2017.

Fundamentos do Processual Penal. $3^{\mathrm{a}}$ ed. São Paulo:

LEMGRUBER, Julita; CANO, Ignacio; MUSUMECI, Leonarda. Olho por olho? O que pensam os cariocas sobre "bandido bom é bandido morto". 
Rio de Janeiro: CESeC, 2017. Disponível em: $<$ http://www.ucamcesec.com.br/wpcontent/uploads/2017/05/CESEC_BBBM_Web_final.pdf>. Acesso em: 3 jun. 2017.

MAIER, Julio B. Derecho procesal penal: parte general - sujetos procesales. Buenos Aires: Ad Hoc, 2000.

Del Puerto, 2004.

Derecho procesal penal: fundamentos. $2^{\mathrm{a}}$ ed. Buenos Aires:

MALAN, Diogo. Ideologia política de Francisco Campos: influência na legislação processual penal brasileira. In: MELCHIOR, Antônio Pedro; MALAN, Diogo; SULOCKI, Victoria-Amália de. Autoritarismo e processo penal brasileiro. Rio de Janeiro: Lumen Juris, 2015.

MARRAFON, Marco Aurélio. Quadro mental paranoico não pode imperar na solução de casos jurídicos. Revista Consultor Jurídico, São Paulo, 14 jul. 2014. Disponível em: <http://www.conjur.com.br/2014-jul14/constituicao-poder-quadro-mental-paranoico-nao-imperar>. Acesso em: 30 mai. 2017.

MEIJUEIRO, Carlos. Um conto de ficção sobre noites drásticas. In: CAVA, Bruno e COCCO, Giuseppe. Amanhã vai ser maior: o levante da multidão no ano que não terminou. São Paulo: Annablume, 2014.

MELCHIOR, Antônio Pedro; MALAN, Diogo; SULOCKI, Victoria-Amália de. Autoritarismo e processo penal brasileiro. Rio de Janeiro: Lumen Juris, 2015.

MELCHIOR, Antônio Pedro; SOARES E SOUZA, Taiguara Libano. Organização criminosa e manifestações populares. Crítica à aplicação da Lei no $12.850 / 13$ na persecução penal em face de manifestantes. Disponível em: <http://www.antoniopedromelchior.adv.br/wpcontent/uploads/2015/05/organizaca-criminosa-e-manifestacoespopulares.pdf>. Acesso em: 23 mai. 17.

MIAILLE, Michel. Uma introdução crítica ao direito. Tradução: Ana Prata. $1^{\mathrm{a}}$ ed. Portugal: Ed. Pax. Braga, 1989.

MORAES, Wallace dos Santos de; MORAES, Luciana Simas Chaves de. As máscaras do Estado repressor: A criminalização dos movimentos sociais no Brasil. Passagens - Revista Internacional de História Política e Cultura Jurídica, v. 8, n. 1, pp. 102-121, jan-abr. 2016.

MUÑOZ CONDE, Francisco. As origens ideológicas do direito penal do inimigo. Revista Brasileira de Ciências Criminais, v. 18, n. 83, mar-abr. 2010. 
NEGRI, Antônio. O poder constituinte: ensaio sobre as alternativas da modernidade. Tradução: Adriano Pilatti. $2^{\mathrm{a}}$ ed. Rio de Janeiro: Lamparina, 2015.

PASSETTI, Edson. A ação direta contra o insuportável. Revista Verve, n. 26, ano 2014, p. 206. Disponível em: <https://revistas.pucsp.br/index.php/verve/article/view/30791/21310>. Acesso em: 25 mai. 2017.

PILATTI, Adriano. O ano das maravilhas e do pesadelo. In: CAVA, Bruno e COCCO, Giuseppe. Amanhã vai ser maior: o levante da multidão no ano que não terminou. São Paulo: Annablume, 2014.

. Junho de 2013 - o direito enunciado tumultuariamente nas ruas. In: CUNHA, José Ricardo (org.), Epistemologias críticas do Direito. Rio de Janeiro: Ed. Lumen Juris, 2016a.

- Crise da representação e demandas de participação: lembranças de junho de 2013 e depois. Artigo não publicado, 2016b.

PORTUGAL, Luisa Pressburguer. Política e estética da política na obra de Jacques Rancière: duas narrativas sobre as manifestações de 2013 no Brasil. Dissertação de mestrado (Departamento de Direito). Pontifícia Universidade Católica do Rio de Janeiro. Rio de Janeiro, 2016.

PRADO, Geraldo. Sistema acusatório: a conformidade constitucional das leis processuais penais. $3^{a}$ ed. Rio de Janeiro: Lumen Juris, 2005.

PRADO, Geraldo et al. Aspectos contemporâneos da criminalização dos movimentos sociais no Brasil. Revista Brasileira de Ciências Criminais, v. 23, n. 112, pp. 245-260, 2015.

SANTOS, Juarez Cirino. O direito penal do inimigo - ou o discurso do direito penal desigual. Disponível em: <http://icpc.org.br/wpcontent/uploads/2012/05/direito_penal_do_inimigo.pdf>. Acesso em: 7 mai. 2017.

SANTOS, Mariana Corrêa dos. Corpos em movimento: black bloc carioca e representações de resistência. In: CAVA, Bruno e COCCO, Giuseppe. Amanhã vai ser maior: o levante da multidão no ano que não terminou. São Paulo: Annablume, 2014.

SERRANO, Pedro. Para Pedro Serrano, o papel do sistema de justiça está substituindo o papel dos militares. Revista Carta Capital, São Paulo, 25 out. 2016.2 Disponível em: <http://justificando.cartacapital.com.br/2016/10/25/para-pedro-serrano-opapel-do-sistema-de-justica-esta-substituindo-o-papel-dos-militares>. Acesso em: 31 mai. 2017. 
SILVA, Valeska Suellen Rodrigues. A Política da Multidão: a Constituição da Democracia do Comum no Pensamento de Antonio Negri. Dissertação de mestrado (Departamento de Direito). Pontifícia Universidade Católica do Rio de Janeiro. Rio de Janeiro, 2014.

TOLEDO, Fabricio. Insubmissão: a multidão forjando sua inteligência. In: CAVA, Bruno e COCCO, Giuseppe. Amanhã vai ser maior: o levante da multidão no ano que não terminou. São Paulo: Annablume, 2014.

VIANA, Natalia. Um espião contra Eloísa Samy. Agência Pública, São Paulo, 31 jan. 2017.2 Disponível em: <http://apublica.org/vigilancia/infiltrados/um-espiao-contra-eloisa-samy/>. Acesso em: 30 mai. 2017.

VIRNO, Paolo. Gramática da multidão: para uma análise das formas de vida contemporâneas. São Paulo: Annablume, 2013.

WARAT, Luis Alberto. Epistemologia e ensino do direito: o sonho acabou. Florianópolis: Fundação Boiteux, 2004.

WARAT, Luis Alberto; CARDOSO, Rosa Maria. Ensino e saber jurídico. Rio de Janeiro: Eldorado, 1977.

ZAFFARONI, Eugenio Raul. Em busca das penas perdidas: a perda da legitimidade do sistema penal. Rio de Janeiro: Revan, 2001. . O inimigo no direito penal. Rio de Janeiro: Revan, 2007.

ZAFFARONI, Eugenio Raul; OLVEIRA, Edmundo. Criminologia e política criminal. Rio de Janeiro: GZ Ed., 2010.

ZAFFARONI, Eugenio Raul; SLOKAR, Alejandro; ALAGIA, Alejandro. Manual de derecho penal: parte general. Buenos Aires: Ediar, 2005. 


\section{ANEXO - Transcrição de entrevista}

\section{Entrevista com o advogado Mario Fabrizio Polinelli}

Entrevistado - Só lembrando que eu fui advogado no processo e você, como também é advogada e militante, sabe muito bem até onde eu posso ir.

Pesquisador - Claro. Na verdade, a intenção é ter uma ideia do background dessa investigação porque o capítulo que mencionei vai tratar de três situações específicas, que é o inquérito que culmina na prisão dos 23, a criação da CEIV, que dá embasamento às investigações da $\mathrm{DRCl}$, que foi uma Comissão criada pelo Cabral na época, e a agilidade na tramitação da Lei de Organizações Criminosas, que também foi usada na prisão de alguns nas manifestações de outubro de 2015, que já foi a derradeira, onde prenderam 200 pessoas.

En - Sobre essa última eu já não tenho nenhum conhecimento.

Pq - A ideia aqui é... Bom, hoje já cheguei a ir na $27^{a}$ Vara só que fui escorraçada de lá, praticamente, pois "os autos estão conclusos para sentença, o juiz está com o processo há anos, que não sei o quê" e aí comecei a procurar quem poderia me ajudar na obtenção de algumas informações do inquérito. $\mathrm{E}$ aí, vi que você estava na capa e decidi pedir sua ajuda.

En - Tá. Eu vou fazer alguns comentários. Esse processo é sigiloso. Alguns dados dele... Eu fui convidado, por exemplo, na PUC - e tenho autorização da minha cliente para falar sobre o processo - porque fui convidado para dar uma palestra uma vez para tratar desse assunto. Eu 
conversei com ela e chegamos à conclusão de que seria adequado, até para divulgar efetivamente o que estava acontecendo. Era do interesse dela, como continua sendo até hoje, divulgar um pouco da extrema violência que foi esse processo. Porque é muito comum a gente ouvir falar, "ah, processo sem prova", "processo que viola garantia" e tal, e eu atuo em muitos processos e nunca vi algo que chegasse próximo do que foi esse processo. A minha cliente (cujo nome não acho necessário citar)...

$\mathbf{P q}-\operatorname{Sim}$

En - O envolvimento dela, de fato, era assim... Não havia um fato concreto contra ela: "fulana de tal, no dia tal, praticou a conduta X, queimou um carro, jogou pedra na polícia, ou o que seja”. Não há, podem procurar. Eu não conheço a fundo as condutas de todos os 23 , eu posso falar desse inquérito pelo o que conheço, que é o que tange essa pessoa específica.

$\mathbf{P q}$ - Certo.

En - Não havia e nunca houve uma conduta direta contra ela. O que existia era: "fulana de tal participou de manifestações". Ponto. Ela foi conduzida à delegacia sem mandado. Sofreu uma busca e apreensão e foi conduzida à delegacia sem mandado. Tentou ficar em silêncio, pediu, requereu expressamente e está consignado no Termo dela, para ficar em silêncio, que ela não ia falar porque não teve acesso ao inquérito policial e eu como advogado dela também não tive porque disseram que o inquérito policial estava na Justiça. Então, nesse meio tempo entre a nossa chegada e o depoimento dela, eu pedi para outros colegas de escritório diligenciarem na $27^{\mathrm{a}}$ Vara, para que descobrissem se o inquérito estava, de fato, lá e não estava. Na verdade, a polícia estava escondendo 
o inquérito da gente. $\mathrm{E}$, na $27^{\mathrm{a}}$ Vara, nós fotografamos - eu não tenho mais essa foto - uma cena, assim, digna de estar nos manuais de processo penal.

Pq - Como processo de inquisição, não é?

En - É! Tinha um aviso no cartório, bem grande, em letras garrafais: "O processo número tal, que era a distribuição desse inquérito, não tramita pelo cartório". O inquérito não passava pelo cartório. A tramitação era direta entre gabinete e delegacia, gabinete e delegacia, gabinete e delegacia... Estava um aviso grande lá porque os advogados procuravam, as pessoas procuravam acesso às peças e era inacessível. O próprio juízo tornou o processo inacessível e ele não passava pelo cartório.

Pq - Inacreditável. E até hoje permanece assim porque hoje fui escorraçada de lá. $\mathrm{E}$, em tese, na boleta dele o processo não aparece como concluso.

En - Mas é, ninguém tem acesso.

Pq - Só que ele levantou o sigilo do processo.

En - Sim, o processo não está mais com sigilo. Mas, mesmo assim, as coisas não funcionam dessa maneira naquele juízo. Aliás, nesse juízo não, nesse processo. Nos outros processos da $27^{\mathrm{a}}$, funciona de maneira normal. Eu já tive outros processos na $27^{\mathrm{a}}$ e funciona de maneira normal. O juiz é um juiz duro, mas funciona da forma que tem que funcionar.

$\mathbf{P q}$ - Sim, funciona. 
En - O juiz tem posições dele, que ele externa nos autos, só que a tramitação do processo é normal. Esse processo não foi normal, esse processo foi um processo foi diferente.

Pq - E continua não sendo normal...

En - Eu posso falar que desde o início. Chegava lá e estava um aviso, não era uma coisa oculta. Isso ficou às claras, estava escrito na entrada do cartório: "o processo tal não tramita pelo cartório, ele tramita direto pelo gabinete". Ponto.

Pq - E a ocasião que você viu isso foi...

En - Eu vi depois. Quem viu primeiro foi um colega de escritório porque eu estava na delegacia para acompanhar a minha cliente e me disseram, isso em 2013, que naquela data, naquele momento, o processo estava no juízo. Então, eu falei, vou pedir a alguém para ir até o cartório para dar acesso. Aí viram isso lá. E, também, a secretaria do juiz disse: "não, o processo não está aqui há vários dias, o processo está na delegacia”. E eles não deram acesso. Então, nós optamos por ficar em silêncio e, como consta no Termo...

Pq - Não pode permanecer em silêncio.

En - Por mais absurdo que possa parecer... Ela tinha acabado de sofrer uma busca e apreensão e foi conduzida à delegacia.

Pq-E chegando lá foi informada de que era testemunha? 
En - Ela era testemunha. Então, agora as pessoas estão fazendo busca e apreensão com testemunha, fazendo busca e apreensão e condução coercitiva sem mandado de testemunha.

Pq - E me conta o que foi apreendido na casa dela. Você lembra?

En - Foi apreendido um ipad, documentos... Eu menciono isso na petição. Foram documentos pessoais, um iPad e pen drives, que não tinham absolutamente nada a ver. Não tinha nada. Os documentos pessoais eram documentos médicos e da faculdade, o iPad ela tinha acabado de ganhar do pai e nunca mais viu porque depois que foi deferida a devolução dos bens, os bens nunca apareceram.

Pq - Nossa!

En - É sério. Sumiram com a nécessaire. Mas isso é o de menos... Vou continuar. Então, ok, ela prestou depoimento, disse, que tá no depoimento, que ela participou das manifestações, não tinha envolvimento com black blocs - o que era verdade. E até as próprias pessoas que eram, que tinham, de fato, algum envolvimento, até sabiam quem ela era, mas falavam: "não, ela não tem nada a ver". E, mesmo assim, a prisão dela foi requerida, foi pedida a prisão temporária e prorrogada

Pq - Prorrogada... Foi 5 com mais 5?

En - Sim. 
Pq - Então, ela ficou 10 dias presa?

En - Ela não chegou a ficar presa porque a prisão não foi executada, porque ela estava fora do Rio. Ela estava fora do Rio no dia da prisão. E a prisão dos demais foi prorrogada e a dela não foi prorrogada porque, como não foi cumprida a primeira, então não houve prorrogação para ela. Mas teria havido com certeza. E aí, no relatório final, que é um peça, assim, bem digna de estar em manuais, consta em relação a ela que ela não sei se exatamente com essas palavras - mas, a conduta efetiva dela teria sido presenciar, porque ela não negou que presenciou, fatos violentos. Algo dessa natureza, não exatamente com essas palavras... É sério.

Pq - É engraçado que a gente é criminalista, não é? E aí, você, como criminalista, olhar e ver um processo desse...

En - Esse é o verdadeiro processo kafkiano. Aquele processo que não tem, em que não há um fato.

Pq - Pois é, não começa, não tem fim.

En - Em relação a ela, não estou falando dos demais. Eu não tenho autorização. Eu conheço o advogado dos demais, posso até colocar você em contato com ele. Ele vai ter o maior prazer, é meu amigo. Um comunista old school, adoro. Ele pode falar dos demais. Mas em relação a ela o que posso dizer é que esse é o verdadeiro processo kafkiano. Do quê efetivamente ela estava sendo acusada? A defesa é a prova diabólica, é uma defesa impossível. Como é que eu vou... O que está sendo capitulado a ela como, o que foi entendido pela polícia como crime de organização criminosa... Não, organização criminosa não, na época era quadrilha ou bando armado. 
Pq - É, pois é.

En - Ela ter presenciado atos violentos na manifestação! O que é uma coisa que, assim, houve uma manifestação aqui no Rio com um milhão de pessoas ali na Presidente Vargas.

Pq - Eu presenciei, você presenciou...

En - Eu estava naquela manifestação e eu presenciei. Eu presenciei atos violentos. E quando eu estive em outras manifestações eu também presenciei atos de violência. Então, em tese, a mesma conduta que ela praticou, eu pratiquei também, você praticou...

Pq - Um milhão de pessoas praticaram.

En - Um milhão de pessoas praticaram a mesma conduta que ela praticou. Se você fosse aplicar a lógica da polícia, a lógica dos investigadores, se a lógica fosse a mesma, então, na verdade, pelo menos $50 \%$ das pessoas que estavam nessas manifestações poderiam estar sendo processadas por quadrilha armada. E ela não foi denunciada.

Pq - E a lógica não se aplica porque não tem lógica. A questão é essa...

En - E aí ela não foi denunciada. E a partir daí...

Pq - E o MP justifica, você lembra se tem uma justificativa? "Deixo de denunciar fulana" ou simplesmente... 
En - Não havia fato concreto. Ele fala algo do tipo, que não havia fato concreto. Mas aí continuou uma outra investigação, instauraram outro inquérito na $\mathrm{DRCl}$, que ela nunca foi chamada.

Pq - Tem vários filhotes, esse inquérito produziu vários filhotes...

En - Ele produziu. Ela não foi chamada no outro inquérito. Eu soube que houve outro inquérito, só que ela não foi chamada para depor. Eu também soube que o inquérito era para investigar essa pessoa. E era para investigar também até professor da PUC. Isso daí eu ouvi como "fofocada", claro, "tá sendo investigado por isso, porque teria financiado". Não sei se é verdade. O outro eu sei que é verdade. Eu sei porque houve diligência concreta, ligada a pessoas próximas, que foram procuradas para saber a participação dele. Enfim, a história que eu tenho para contar desse processo é essa. A última... Tem mais um detalhe que eu acho que talvez seja relevante para você. Eu fui interceptado também, né...

$P q-A h$, é?

En - Eu não sofri a interceptação diretamente, mas eu caí na interceptação com ela. Mas outros advogados foram interceptados, você deve conhecer bem isso.

Pq - Sim, na época eu devo ter sido também. Eu era voluntária, né...

En - Eu caí. Eu lá tive várias vezes também, para ajudar. Só que não podia me envolver muito por causa do escritório, porque tinha a situação dela, imaginava que poderia ter algum conflito depois... 
Pq - Claro.

En - Agora, outra coisa que foi bastante desagradável, para dizer o mínimo, é que a polícia não deu vista do inquérito de maneira nenhuma. Tive que pedir ao Itabaiana, nessa petição aqui, tá tudo aqui, que eu tive que pedir ao Itabaiana o acesso, ele deferiu, oficiou à $\mathrm{DRCl}$ e o que que a $\mathrm{DRCl}$ fez, que eu só fiquei sabendo depois? Eu achei estranho na época, mas não tinha muito o que fazer. Eles não me deram vista de imediato, me deram vista 24 horas depois que receberam o ofício. Nesse meio tempo, claro que eu só descobri depois, eles renumeraram o processo, o inquérito todo, retiraram as provas relevantes, os elementos importantes do inquérito, eles retiraram, e criaram um apenso secreto. Eles criaram um apenso secreto. A gente só teve acesso a esse apenso quando veio a denúncia depois. Então, eles deram vista daquilo que eles quiseram dar vista. Não deram vista do... antes, não entregaram. Por conta da decisão judicial que os obrigou a dar acesso aos autos, eles sacaram os elementos dos autos e criaram o apenso.

Pq - Mas esse apenso secreto, você teve acesso e você lembra o que que tinha?

En - Quando eu tive acesso, quando o vi isso depois e quando ficamos sabendo disso, foi quando saiu a denúncia. E, na denúncia, eu já...

Pq - Ah, você viu que ela não tinha sido denunciada...

En - Ela não foi denunciada. Então, aí perdeu...

Pq - Perdeu seu interesse profissional nisso, claro. E graças a Deus por isso, não é... 
En - Exatamente. Até mesmo porque esse processo está até hoje lá e é inacreditável que o processo não tenha sido ainda concluído. E todo mundo sabe o resultado. Todo mundo sabe que a maioria vai ser condenada e...

Pq - Ele está só empurrando com a barriga.

En - Ele não está empurrando com a barriga, não. Salvo engano, tem um habeas corpus no STJ que está sendo julgado e ele está esperando o resultado do habeas corpus para proferir sentença.

Pq - Me diz uma coisa: você foi interceptado e você chegou a ver algum diálogo seu transcrito?

En - Vi, mas eu não lembro. É... Tem um diálogo em que eu a oriento para não falar mais no celular porque era para tomar cuidado, porque ela devia estar sendo interceptada.

$\mathbf{P q}$ - Como estava.

En - Porque ela ficava me ligando do celular toda hora, aí chegou uma hora que eu disse "pô"... Não tem a transcrição, mas eles só colocaram "Mario fala para tomar cuidado porque poderia haver interceptação". Na verdade, eu falei para ela, "pô", eu explodi na hora e falei "não me liga mais do telefone"!

Pq - É claro. Só que é difícil de os clientes entenderem isso, não é... 
En - E tem outra... Até porque, assim, ela é uma menina de 29, 20 anos, sem malícia do... Uma pessoa que nunca imaginou que iria passar por um episódio daquele na vida. Não é uma pessoa que saiu para cometer um crime. Quem sai para cometer um delito, sabe que pode acontecer...

Pq - Se precavê, não é...

En - Se amanhã eu saio com uma arma para praticar um roubo no ônibus, eu sei que estou sujeito que algo me aconteça. Uma pessoa que vai a uma manifestação, não é uma pessoa que está saindo com a intenção de... Em princípio, não é uma pessoa que está saindo com a intenção de cometer um delito. Então, acontece esse problema todo e a pessoa não tem a maldade, a malícia de se precaver contra as investigações dessa maneira, que é uma coisa muito afastada da realidade dela. Então, se o advogado fala "não liga pra mim, não usa o telefone, se quer falar comigo, fala por whatsapp só, não usa a linha de telefone convencional", a pessoa não entende.

Pq - Claro... Bom, muitíssimo obrigada. Você realmente ajudou muito. 